Supporting Information for:

\title{
Connecting Organometallic Ni(III) and Ni(IV): Reactions of Carbon-Centered Radicals with High-Valent Organonickel Complexes
}

James R. Bour, Devin M. Ferguson, Edward J. McClain, Jeff W. Kampf, and Melanie S. Sanford*

Department of Chemistry, University of Michigan, 930 North University Avenue, Ann Arbor, Michigan 48109, USA

\section{Table of Contents}

I. General Experimental and Materials and Methods

p. S2

II. Safety Note

p. S3

III. Synthesis of $\mathrm{NMe}_{4}\left[4-\mathrm{FC}_{6} \mathrm{H}_{4} \mathrm{CO}_{2}\right]$

p. S3

IV. Synthesis of $\mathrm{Ni}^{\mathrm{III}}$ and $\mathrm{Ni}^{\mathrm{IV}}$ Complexes

p. S4

V. Radical Capture at $\mathrm{Ni}^{\mathrm{III}}$

p. $\mathrm{S13}$

VI. Radical C-C Coupling

p. S23

VII. EPR and DFT Analysis

p. S36

VIII. References

p. $\$ 38$

IX. Spectral Data

p. S39

X. Crystallography Details

p. $\$ 67$ 


\section{General Experimental}

All manipulations were performed inside an $\mathrm{N}_{2}$-filled glovebox unless otherwise noted. NMR spectra were obtained on a Varian VNMR $700\left(699.76 \mathrm{MHz}\right.$ for ${ }^{1} \mathrm{H} ; 175.95 \mathrm{MHz}$ for $\left.{ }^{13} \mathrm{C}\right)$, Varian VNMR $500\left(500.09 \mathrm{MHz}\right.$ for ${ }^{1} \mathrm{H} ; 470.56 \mathrm{MHz}$ for ${ }^{19} \mathrm{~F} ; 125.75 \mathrm{MHz}$ for $\left.{ }^{13} \mathrm{C}\right)$, or Varian VNMR $400\left(401 \mathrm{MHz}\right.$ for ${ }^{1} \mathrm{H}$; $376 \mathrm{MHz}$ for ${ }^{19} \mathrm{~F} ; 123 \mathrm{MHz}$ for $\left.{ }^{13} \mathrm{C}\right)$ spectrometer. ${ }^{1} \mathrm{H}$ and ${ }^{13} \mathrm{C}$ NMR chemical shifts are reported in parts per million (ppm) relative to TMS, with the residual solvent peak used as an internal reference. ${ }^{19} \mathrm{~F}$ NMR chemical shifts are reported in ppm and are referenced to fluorobenzene $(-113.52 \mathrm{ppm})$. The ${ }^{11} \mathrm{~B}$ NMR spectra are referenced to $\mathrm{BF}_{3} \bullet \mathrm{Et}_{2} \mathrm{O}$. Abbreviations used in the NMR data are as follows: $\mathrm{s}$, singlet; d, doublet; t, triplet; q, quartet; m, multiplet; br, broad signal; br. q, broad signal quartet; $p$, pentet. Yields of reactions that generate fluorinated products were determined by ${ }^{19} \mathrm{~F}$ NMR spectroscopic analysis using a relaxation delay of $25 \mathrm{~s}$ with at $90^{\circ}$ pulse angle. Yields determined by ${ }^{1} \mathrm{H}$ NMR spectroscopic analysis were determined using a relaxation delay of $25 \mathrm{~s}$. Mass spectral data were obtained on a Micromass Magnetic Sector Mass Spectrometer in electrospray ionization mode. Elemental analyses were conducted by Midwest Microlabs. X-ray crystallographic data were collected on a Rigaku AFC10K Saturn 944+ CCD-based X-ray diffractometer. EPR spectra were collected at $-176{ }^{\circ} \mathrm{C}$ using a Bruker EMX ESR Spectrometer with a nitrogen-cooled cryostat. Flash chromatography was performed using a Biotage Isolera One system with cartridges containing high performance silica gel.

\section{Materials and Methods}

The following compounds were prepared according to the literature procedures: $\mathrm{NMe}_{4} \mathrm{Tp},{ }^{1}$

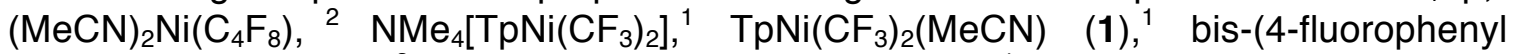
benzoyl)peroxide (A), ${ }^{3}$ bis-(4-phenylbutryl)peroxide (B), ${ }^{4}$ 4-fluorobenzene diazonium tetrafluoroborate, ${ }^{5}$ 2,6-difluorobenzene diazonium tetrafluoroborate, ${ }^{5}$ 4fluoroethylbenzene. ${ }^{6}(\mathrm{MeCN}) \mathrm{Ni}\left(\mathrm{CF}_{3}\right)_{2}{ }^{7}$ was synthesized via a modification of a literature procedure, wherein the $\mathrm{AgBr}$ was separated through centrifugation at $5000 \mathrm{rpm}$ for $5 \mathrm{~min}$ under $\mathrm{N}_{2}$ and decanted. Unless otherwise noted, all commercial compounds were used as received. S-Trifluoromethyl dibenzothiophenium, dicyclohexylcarbodiimide, and 1,4dinitrobenzene were purchased from Acros. $\beta$-Nitrostyrene was purchased from Alfa Aesar. 2,6-Difluoroaniline, $\mathrm{TMAOH} \cdot 5 \mathrm{H}_{2} \mathrm{O}$, and 4-phenylbutyric acid were purchased from Sigma Aldrich. Sodium nitrite was purchased from Sigma Aldrich and was stored in a desiccator when not in use. lodomethane was purchased from Sigma Aldrich and dearated through a standard freeze-pump-thaw procedure before use. 4-fluorobenzoic acid was purchased from Matrix Scientific. Xenon difluoride $\left(\mathrm{XeF}_{2}\right)$ and ferrocene were purchased from Strem Chemicals. $\mathrm{CD}_{2} \mathrm{Cl}_{2}$, and $\mathrm{CD}_{3} \mathrm{CN}$ were obtained from Cambridge Isotopes Laboratories and were stored over activated $3 \AA$ molecular sieves (EMD Millipore) or basic alumina. $\mathrm{CD}_{3} \mathrm{NO}_{2}$ was purchased from Cambridge Isotope Labs or Sigma Aldrich. Anhydrous nitromethane over $3 \AA$ molecular sieves was purchased from Sigma Aldrich and was used within two weeks. MeOH was purchased from VWR. Dichloromethane (DCM) used in the glovebox was purchased from Fisher Scientific and was deaerated by sparging with $\mathrm{N}_{2}$ and was dried using an Innovative Technology, Inc. (now rebranded to Inert) solvent purification system. Trifluoroacetic anhydride was purchased from Alfa Aesar and was dearated with three careful freeze-pump-thaw cycles. Sodium peroxide was purchased from Acros and was

stored in an inert atmosphere glove box. Basic alumina (Aldrich) was dried for two days 
under vacuum at $210^{\circ} \mathrm{C}$. Silica gel was dried under vacuum at $130^{\circ} \mathrm{C}$ for one day. Celite was dried for $12 \mathrm{~h}$ under vacuum at $100^{\circ} \mathrm{C}$. Molecular sieves were dried under vacuum at $180^{\circ} \mathrm{C}$ for $3 \mathrm{~d}$. Unless otherwise noted, all glassware and magnetic stir bars were dried overnight in an oven at $150{ }^{\circ} \mathrm{C}$ and cooled under an inert atmosphere before use. All commercial reagents were used without further purification/drying unless explicitly stated in the experimental section.

\section{Safety Note}

Organic peroxides were used extensively throughout the course of these studies. All organic peroxides should be considered to be an explosion hazard and were thus handled with extreme care and on small scales. When at all possible, liquid phase vessel transfers, small reaction scales, appropriate personal protective equipment, and blast shields were used to mitigate risk.

\section{Synthesis of $\mathrm{NMe}_{4}\left[4-\mathrm{F}-\mathrm{C}_{6} \mathrm{H}_{4} \mathrm{CO}_{2}\right]$}

On the bench top, to a $100 \mathrm{~mL}$ round bottom flask containing a magnetic stirbar were added $\mathrm{TMAOH} \cdot 5 \mathrm{H}_{2} \mathrm{O}(4.25 \mathrm{~g}, 23.4 \mathrm{mmol}, 1.00$ equiv) and $\mathrm{MeOH}(25 \mathrm{~mL}, 0.94 \mathrm{M})$ followed by 4-fluorobenzoic acid ( $3.29 \mathrm{~g}, 23.4 \mathrm{mmol}, 1.00$ equiv). The mixture was stirred at rt for $16 \mathrm{~h}$. The resulting reaction mixture was filtered through a cotton plug and concentrated to afford a yellow oil. $\mathrm{Et}_{2} \mathrm{O}(50 \mathrm{~mL})$ was added, and the mixture was sonicated, yielding a small amount of solid precipitate. The mixture was concentrated under vacuum, and EtOAc $(50 \mathrm{~mL})$ was added to the resulting oil. This mixture was sonicated resulting in the formation of a significant amount of white solid. The mixture was concentrated to afford a low melting solid. This process (with EtOAc) was repeated 4 times, ultimately affording a white solid. This solid was dried under vacuum for $30 \mathrm{~min}$. It was then transferred into a glovebox, and MeCN (12 mL) was added. The mixture was agitated resulting in a suspension. The solvent was removed under vacuum yielding the product as a white solid (4.08 $\mathrm{g}, 82 \%$ yield).

${ }^{1} \mathrm{H}$ NMR $\left(400 \mathrm{MHz}, \mathrm{CD}_{3} \mathrm{CN}, 25^{\circ} \mathrm{C}\right): \delta 7.94(\operatorname{app} \mathrm{dd}, J=8.5,6.1 \mathrm{~Hz}, 2 \mathrm{H}), 6.96$ (app t, $J=$ $8.9 \mathrm{~Hz}, 2 \mathrm{H}), 3.18(\mathrm{~s}, 12 \mathrm{H})$

${ }^{19} \mathrm{~F}$ NMR $\left(377 \mathrm{MHz}, \mathrm{CD}_{3} \mathrm{CN}, 25^{\circ} \mathrm{C}\right): \delta-117.24(\mathrm{~m}, 1 \mathrm{~F})$.

${ }^{13} \mathrm{C}$ NMR (176 MHz, $\left.\mathrm{CD}_{3} \mathrm{CN}, 25^{\circ} \mathrm{C}\right): \delta 169.21,164.07$ (d, J=242 Hz), 139.53, 132.09 (d, $J=8.3 \mathrm{~Hz}), 114.27(\mathrm{~d}, J=21 \mathrm{~Hz}), 55.99-55.94(\mathrm{~m})$. 


\section{Synthesis of $\mathrm{Ni}^{\mathrm{III}}$ and $\mathrm{Ni}^{\mathrm{iV}}$ Complexes}

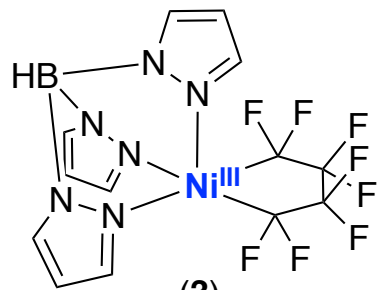

(3)

Synthesis of $\mathrm{TpNi}^{\text {III }}\left(\mathrm{C}_{4} \mathrm{~F}_{8}\right)(3)$ : A $20 \mathrm{~mL}$ vial was charged with $\mathrm{NMe}_{4} \mathrm{Tp}^{1}(144 \mathrm{mg}, 0.5$ mmol, 1 equiv), $(\mathrm{MeCN})_{2} \mathrm{Ni}\left(\mathrm{C}_{4} \mathrm{~F}_{8}\right)^{2}(150 \mathrm{mg}, 0.5 \mathrm{mmol}, 1$ equiv), and a magnetic stir bar. THF $(10 \mathrm{~mL})$ was added, and the resulting solution was stirred for $1 \mathrm{~h}$. The volatiles were removed under vacuum. The solid was re-suspended in THF $(15 \mathrm{~mL})$ with vigorous stirring. In a separate $4 \mathrm{~mL}$ vial, $\mathrm{AgBF}_{4}(99 \mathrm{mg}, 0.51 \mathrm{mmol}, 1.02$ equiv) was dissolved in a minimum volume of THF ( $2 \mathrm{~mL})$. This solution was then added in one portion to the vigorously stirring reaction solution. Upon addition, the mixture changed from a yelloworange suspension to an orange solution with a gray $\mathrm{Ag}^{0} / \mathrm{NMe}_{4} \mathrm{BF}{ }_{4}$ precipitate. The solution was stirred for 5 min before the vial was removed from the glove box. The reaction was filtered through a glass frit, and the frit was washed $\mathrm{Et}_{2} \mathrm{O}(2 \mathrm{~mL})$. The filtrate was concentrated under vacuum. The resulting solid was dissolved in $\mathrm{CH}_{2} \mathrm{Cl}_{2}(2 \mathrm{~mL})$ and purified by silica column chromatography using 5:1 hexanes:ethyl acetate. The productcontaining fractions were collected and concentrated under vacuum to afford an oily red residue. This oil was redissolved in anhydrous benzene $(5 \mathrm{~mL})$. The yellow-green solution was concentrated under reduced pressure to afford a dark green solid. The solid further lyophilized from anhydrous benzene $(2 \mathrm{~mL})$ to yield 3 as a bright green solid $(135 \mathrm{mg}$, $57 \%$ yield).

${ }^{11} \mathrm{~B}$ NMR $\left(225 \mathrm{MHz}, \mathrm{CH}_{3} \mathrm{NO}_{2}\right) \delta-3.26$ (s)

Elemental analysis: calculated for $\mathrm{C}_{13} \mathrm{H}_{10} \mathrm{~N}_{6} \mathrm{BF}_{9} \mathrm{Ni}, \mathrm{C}: 33.10, \mathrm{H}: 2.14, \mathrm{~N}: 17.81$; Found: C: 33.34, H: 2.31, N: 18.01

$\mu_{\text {eff }}($ Evan's method $)=1.84$ 


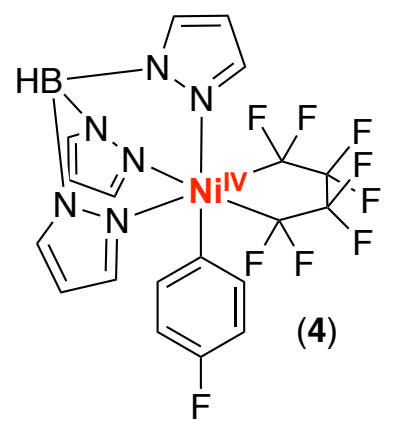

Isolation of $\mathrm{TpNi}^{\mathrm{iV}}\left(\mathrm{C}_{4} \mathrm{~F}_{8}\right)\left(\mathbf{4}-\mathrm{F}-\mathrm{C}_{6} \mathrm{H}_{4}\right)(\mathbf{4}): \mathrm{A} 20 \mathrm{~mL}$ vial was charged with $\mathrm{TpNi}\left(\mathrm{C}_{4} \mathrm{~F}_{8}\right)(\mathbf{3}, 20$ $\mathrm{mg}, 0.042 \mathrm{mmol}, 1$ equiv) and bis-(4-fluorobenzoyl)peroxide $(\mathbf{A}, 213 \mathrm{mg}, 0.77 \mathrm{mmol}, 18$ equiv). The solids were then dissolved in anhydrous $\mathrm{CH}_{3} \mathrm{NO}_{2}(2.7 \mathrm{~mL})$. The vial was capped with a Teflon-lined cap, removed from the glovebox, and heated at $95^{\circ} \mathrm{C}$ for 20 min. Over the course of the reaction, the solution changed from a bright green to yellow/brown. Note: A yellow, orange, or red solution before heating indicates the presence of a Lewis basic impurity, usually water. The presence of Lewis basic impurities results in lower yields of 4 . After heating, the vial was allowed to stand at room temperature for $20 \mathrm{~min}$. The volatiles were removed under a gentle stream of $\mathrm{N}_{2}$. The vial was charged with a magnetic stir bar, and the sticky solid was stirred with $1.5 \mathrm{~mL}$ of $1: 1$ mixture of hexanes:ethyl acetate. After $30 \mathrm{~min}$, this suspension was loaded directly onto a silica column and was purified using a 98:2 hexanes:ethyl acetate mobile phase. The compound was isolated as a light yellow-orange powder in $31 \%$ yield $(7.6 \mathrm{mg})$.

Note: 4 is mildly light sensitive. Though no precautions were taken to exclude light during the synthesis, it is best stored in a cold and dark place. Prolonged storage in ambient light leads to decomposition.

${ }^{1} \mathrm{H} \mathrm{NMR}\left(500 \mathrm{MHz}, \mathrm{CD}_{3} \mathrm{NO}_{2}\right) \delta 7.77(\mathrm{~d}, J=2.2 \mathrm{~Hz}, 2 \mathrm{H}), 7.61(\mathrm{~d}, J=2.1 \mathrm{~Hz}, 1 \mathrm{H}), 7.55(\mathrm{t}$, $J=2.2 \mathrm{~Hz}, 1 \mathrm{H}), 7.27(\mathrm{~d}, J=2.1 \mathrm{~Hz}, 2 \mathrm{H}), 6.30(\mathrm{t}, J=9 \mathrm{~Hz}, 2 \mathrm{H}), 6.10(\mathrm{q}, J=2.2 \mathrm{~Hz}, 1 \mathrm{H})$, $6.06(\mathrm{t}, J=2.2 \mathrm{~Hz}, 1 \mathrm{H}), 5.76(\mathrm{bs}, 2 \mathrm{H}) 4.72-4.21(\mathrm{br}, 1 \mathrm{H})$

${ }^{11} \mathrm{~B}$ NMR $\left(128 \mathrm{MHz}, \mathrm{CD}_{3} \mathrm{NO}_{2}, 23^{\circ} \mathrm{C}\right) \delta-4.32(\mathrm{~d}, J=115.5 \mathrm{~Hz})$.

${ }^{13} \mathrm{C}$ NMR $\left(126 \mathrm{MHz}, \mathrm{CD}_{3} \mathrm{NO}_{2}, 23{ }^{\circ} \mathrm{C}\right) \delta 160.89(\mathrm{~d}, J=243.5 \mathrm{~Hz}), 143.19(\mathrm{~d}, J=8.3 \mathrm{~Hz})$, 142.99 (t, $J=10.5 \mathrm{~Hz}$ ), 136.44, 135.7-135.3 (multiple peaks, 2C, 112.85, 112.68, 106.96, 105.66 .

Note: Due to extensive ${ }^{19} \mathrm{~F}-{ }^{13} \mathrm{C}$ coupling, the ${ }^{13} \mathrm{C}$ resonances in the $\mathrm{NiC}_{4} \mathrm{~F}_{8}$ ring of complex 4 could not be resolved. ${ }^{2}$

${ }^{19} \mathrm{~F}$ NMR (471 MHz, $\left.\mathrm{CD}_{3} \mathrm{NO}_{2}, 23{ }^{\circ} \mathrm{C}\right) \delta-71.16$ (dd, $\left.J=165.5,9 \mathrm{~Hz}, 2 \mathrm{~F}\right),-78.40$ (dd, $J=$ 165.2, 8.6 Hz, 2F), -118.33 (d, J = $259 \mathrm{~Hz}, 2 \mathrm{~F}$ ), -120.46 (d, J = $259 \mathrm{~Hz}, 2 \mathrm{~F}),-120.96$ (s).

Elemental analysis: calculated for $\mathrm{C}_{19} \mathrm{H}_{14} \mathrm{~N}_{6} \mathrm{BF}_{9} \mathrm{Ni}, \mathrm{C}: 40.26, \mathrm{H}: 2.49, \mathrm{~N}: 14.83$; Found: C: 40.40, H: 2.53, N: 14.83 


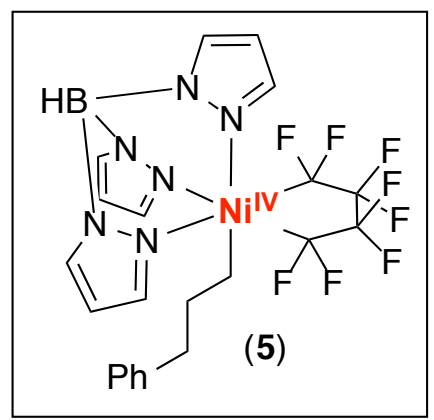

Isolation of $\mathrm{TpNi}^{\mathrm{IV}}\left(\mathrm{C}_{4} \mathrm{~F}_{8}\right)\left(\mathrm{CH}_{2} \mathrm{CH}_{2} \mathrm{CH}_{2} \mathrm{Ph}\right)(5)$ : Note: 5 is light sensitive; thus, precautions should be taken at each step to avoid light. A $20 \mathrm{~mL}$ vial was charged with $\mathrm{TpNi}\left(\mathrm{C}_{4} \mathrm{~F}_{8}\right)(3)$ (40 mg, $0.084 \mathrm{mmol}, 1$ equiv) and bis-(4-phenylbutryl)peroxide (B, $132 \mathrm{mg}, 0.42 \mathrm{mmol}, 5$ equiv). The solids were dissolved in anhydrous $\mathrm{CH}_{3} \mathrm{NO}_{2}(5 \mathrm{~mL})$. The vial was capped with a Teflon-lined cap, wrapped in aluminum foil, removed from the glovebox, and heated at $85^{\circ} \mathrm{C}$ for $6 \mathrm{~min}$. Over the course of the reaction the solution changed from a bright green to orange/brown. Note: A yellow or red solution before heating indicates the presence of a Lewis basic impurity, usually water. After heating, the vial was placed in ice water for 5 $\min$. With the vial still wrapped in aluminum foil to exclude light, the volatiles were removed under a gentle stream of $\mathrm{N}_{2}$. The vial was then charged with a magnetic stir bar, and the residue was stirred with $1.5 \mathrm{~mL}$ of a 3:1 mixture of hexane: ethyl acetate. After $10 \mathrm{~min}$, the resulting solution was loaded directly on to a silica column and was purified using a 99:1 hexanes: ethyl acetate mobile phase. The title compound was isolated as a light orange powder $(8.4 \mathrm{mg}, 17 \%$ yield). The low isolated yield results from challenges associated with separating the large quantities of unreacted $\mathbf{B}$, which has a similar $R_{F}$ as $\mathbf{5}$.

Note: NMR spectra were recorded at $-25^{\circ} \mathrm{C}$ in $C D_{3} \mathrm{CN}$ to avoid decomposition of 5

${ }^{1} \mathrm{H}$ NMR $\left(700 \mathrm{MHz}, \mathrm{CD}_{3} \mathrm{CN},-25{ }^{\circ} \mathrm{C}\right) \delta 7.95(\mathrm{~d}, J=2.3 \mathrm{~Hz}, 2 \mathrm{H}), 7.88(\mathrm{~d}, J=2.3 \mathrm{~Hz}, 2 \mathrm{H})$, $7.73(\mathrm{~d}, J=2.3 \mathrm{~Hz}, 1 \mathrm{H}), 7.68(\mathrm{~d}, J=2.5 \mathrm{~Hz}, 1 \mathrm{H}), 7.20(\mathrm{t}, J=7.6 \mathrm{~Hz}, 2 \mathrm{H}), 7.15(\mathrm{t}, J=7.3$ $\mathrm{Hz}, 1 \mathrm{H}), 6.91-6.85(\mathrm{~m}, 2 \mathrm{H}), 6.38(\mathrm{t}, J=2.4 \mathrm{~Hz}, 2 \mathrm{H}), 6.20(\mathrm{t}, J=2.3 \mathrm{~Hz}, 1 \mathrm{H}), 4.78-4.26$ (multiple peaks, 3H), $2.34(\mathrm{t}, J=7.7 \mathrm{~Hz}, 2 \mathrm{H}), 0.58(\operatorname{app} p, J=7.8 \mathrm{~Hz}, 2 \mathrm{H})$.

${ }^{11} \mathrm{~B}$ NMR $\left(225 \mathrm{MHz}, \mathrm{CD}_{3} \mathrm{CN},-25^{\circ} \mathrm{C}\right) \delta-4.27$ (br)

${ }^{13} \mathrm{C}$ NMR $\left(176 \mathrm{MHz}, \mathrm{CD}_{3} \mathrm{CN},-25{ }^{\circ} \mathrm{C}\right) \delta 145.71,144.76,144.68,143.20,139.29,137.66$, $130.98,128.73,109.52,107.98,73.28-73.56(\mathrm{~m}), 40.81,35.63$.

Note: Due to extensive ${ }^{19} \mathrm{~F}-{ }^{13} \mathrm{C}$ coupling, the ${ }^{13} \mathrm{C}$ resonances in the $\mathrm{Ni}\left(\mathrm{C}_{4} \mathrm{~F}_{8}\right)$ ring of complex 5 could not be resolved. ${ }^{2}$

${ }^{19} \mathrm{~F}$ NMR $\left(471 \mathrm{MHz}, \mathrm{CD}_{3} \mathrm{CN}-25^{\circ} \mathrm{C}\right) \delta-84.72(\mathrm{~d}, J=181.2 \mathrm{~Hz}),-94.26(\mathrm{~d}, J=181.6 \mathrm{~Hz})$, $-131.82(\mathrm{~d}, J=252 \mathrm{~Hz}),-133.25(\mathrm{~d}, J=252 \mathrm{~Hz})$. 


\section{Isolation of $\mathrm{TpNi}^{\mathrm{iV}}\left(\mathrm{C}_{4} \mathrm{~F}_{8}\right)\left(4-\mathrm{FC}_{4} \mathrm{H}_{4} \mathrm{CO}_{2}\right)($ Int-1):}

Scheme S1 Synthetic route to Int-1
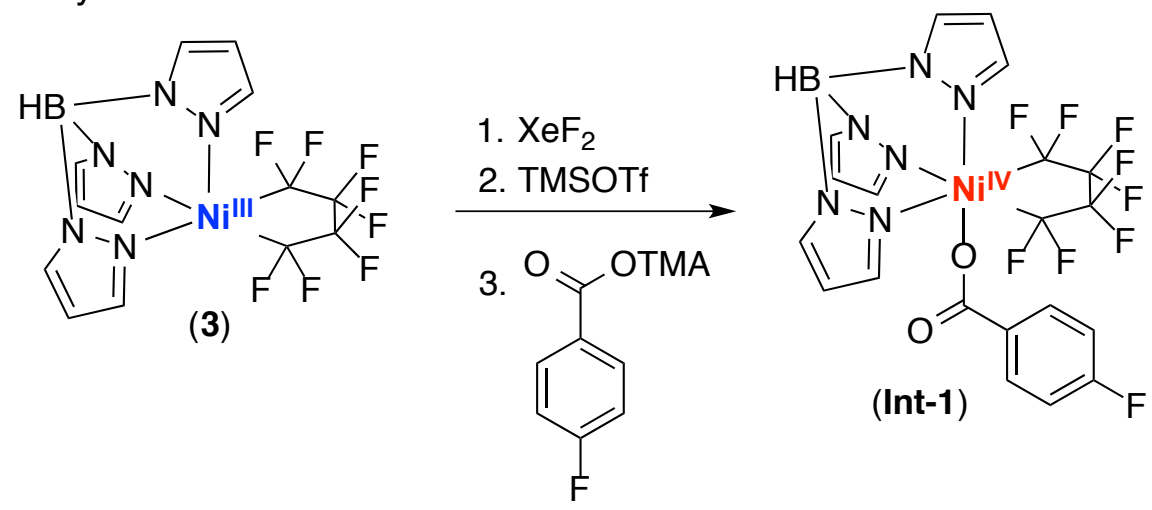

In a nitrogen-filled glovebox, 3 (67 mg, $0.14 \mathrm{mmol}, 1.0$ equiv) and DCM (7.1 mL) were added to a $20 \mathrm{~mL}$ scintillation vial containing a magnetic stirbar. To a separate $4 \mathrm{~mL}$ scintillation vial was added $\mathrm{XeF}_{2}$ (24 mg, $0.14 \mathrm{mmol}, 1.0$ equiv) and DCM (1.4 mL). Both mixtures were agitated until they became homogeneous. The vials were placed in the glovebox freezer $\left(-35^{\circ} \mathrm{C}\right)$ for $45 \mathrm{~min}$. The solution of $\mathrm{XeF}_{2}$ in $\mathrm{DCM}$ was added in one portion to the stirring solution of 3 in $\mathrm{DCM}$. Upon addition of $\mathrm{XeF}_{2} / \mathrm{DCM}$, the reaction mixture changed color from green to orange. The reaction was allowed to stir at rt for 20 min. During this time, TMSOTf (32 $\mathrm{mg}, 0.14 \mathrm{mmol}, 1.0$ equiv) and DCM (1.4 mL) were added to a new $4 \mathrm{~mL}$ scintillation vial, and the vial was agitated to ensure a homogeneous solution. After the reaction of 3 and $\mathrm{XeF}_{2}$ had stirred for $20 \mathrm{~min}$, the solution of TMSOTf/DCM was added in one portion, resulting in a color change from orange to dark orange. This mixture was allowed to stir at rt for $1 \mathrm{~min}$. Tetramethylammonium 4fluorobenzoate (36 mg, $0.17 \mathrm{mmol}, 1.2$ equiv) was then added in one portion. The vial that contained the tetramethylammonium 4-fluorobenzoate was washed with $\sim 0.5 \mathrm{~mL}$ of the reaction mixture, and this wash was returned to the reaction vial. The reaction was stirred vigorously at $\mathrm{rt}$ for $20 \mathrm{~min}$ and then concentrated to afford a dark orange residue. The residue was extracted with pentane until the pentane extracts were colorless $(\sim 15 \times 1 \mathrm{~mL}$ extractions). Each extract was filtered through a Kimwipe pipette plug into a $20 \mathrm{~mL}$ scintillation vial. The vial was placed in the glovebox freezer $\left(-35^{\circ} \mathrm{C}\right)$ for $2 \mathrm{~h}$ resulting in the formation of colorless needles and maroon crystals. The mother liquor was decanted, and the resulting solid was partially dissolved in pentane $(\sim 1 \mathrm{~mL})$. Dichloromethane was added until all material went into solution. The vial was placed in the glovebox freezer($35^{\circ} \mathrm{C}$ ) for $30 \mathrm{~min}$. Colorless needles of 4 -fluorobenzoic acid formed, and the mother liquor was decanted and filtered through a Kimwipe pipette plug into a new vial. The orange solution was the concentrated to afford the product as a red-orange solid $(17.5 \mathrm{mg}, 20 \%$ yield). ${ }^{1} \mathrm{H}$ and ${ }^{19} \mathrm{~F}$ NMR showed the presence of 4 -fluorobenzoic acid as an impurity (13\% of total material). Attempts to purify the compound further resulted in reduced yields and additional decomposition of the title complex. The reported yield is corrected for the presence of 4-fluorobenzoic acid. 
${ }^{1} \mathrm{H}$ NMR $\left(500 \mathrm{MHz}, \mathrm{CD}_{2} \mathrm{Cl}_{2}, 25^{\circ} \mathrm{C}\right): \delta 7.89$ (app d, J = 2.3 Hz, 2H), 7.78-7.71 (multiple peaks, $5 \mathrm{H}$ ), $7.65(\operatorname{app~q,~J~=~3.4~Hz,~1H),~} 6.99$ (app t, J = 8.6 Hz, $2 \mathrm{H}$ ), 6.34-6.27 (multiple peaks, $3 \mathrm{H})$.

${ }^{11} \mathrm{~B}$ NMR $\left(128 \mathrm{MHz}, \mathrm{CD}_{2} \mathrm{Cl}_{2}, 25^{\circ} \mathrm{C}\right): \delta-4.22(\mathrm{~d}, \mathrm{~J}=119.9 \mathrm{~Hz})$.

${ }^{19} \mathrm{~F}$ NMR $\left(471 \mathrm{MHz}, \mathrm{CD}_{2} \mathrm{Cl}_{2}, 25^{\circ} \mathrm{C}\right): \delta-67.04(\mathrm{~d}, \mathrm{~J}=79.1 \mathrm{~Hz}, 2 \mathrm{~F}),-74.20(\mathrm{~d}, \mathrm{~J}=79.1 \mathrm{~Hz}$, 2F), -110.19 (s, 1F), -122.36 (app d, J = 6.5 Hz, 4F).

During the acquisition of a ${ }^{13} \mathrm{C}$ NMR spectrum, Int-1 partially decomposed into unidentifiable products. The spectrum is shown below. 


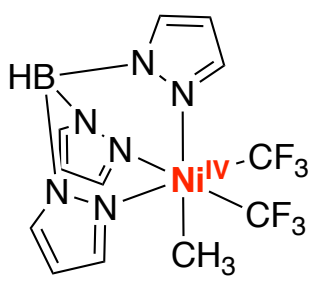

(6)

Synthesis of $\mathrm{TpNi}^{\mathrm{IV}}\left(\mathrm{CF}_{3}\right)_{2}\left(\mathrm{CH}_{3}\right)(6)$ : Note: 6 is light sensitive and should be stored in a dark place. Extended manipulations in direct light can result in diminished yields. A $20 \mathrm{~mL}$

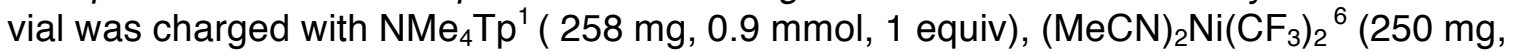
0.90 mmol, 1 equiv), anhydrous $\mathrm{CH}_{3} \mathrm{NO}_{2}(4 \mathrm{~mL})$, and a magnetic stir bar. The resulting solution was stirred for $1 \mathrm{~min}$, and then $\mathrm{CH}_{3} \mathrm{l}(1.1 \mathrm{~mL}, 18 \mathrm{mmol}, 20$ equiv) was added in one portion. In a separate vial, 2,6-difluorobenzene diazonium tetrafluoroborate $(273 \mathrm{mg}$, $1.2 \mathrm{mmol}, 1.3$ equiv) was dissolved in $\mathrm{CH}_{3} \mathrm{NO}_{2}(\sim 1.5 \mathrm{~mL})$. Upon addition of the aryl diazonium solution to the solution of $\left[\mathrm{TpNi}\left(\mathrm{CF}_{3}\right)_{2}\right]^{-}$, the solutions immediately bubbled vigorously and turned dark brown. The vial was then removed from the drybox, and the volatiles were removed under a gentle stream of $N_{2}$. A 1:1 mixture of hexanes: ethyl acetate $(2 \mathrm{~mL})$ was added the residue, and this mixture was stirred for $20 \mathrm{~min}$. This solution was loaded directly onto a silica gel column and was purified using a gradient from pure hexane to 95:5 hexanes:ethyl acetate). The volatiles were removed under vacuum to yield 6 as an off-white powder (153 mg, $40 \%$ yield).

${ }^{1} \mathrm{H}$ NMR $\left(700 \mathrm{MHz}, \mathrm{CD}_{3} \mathrm{CN}, 23^{\circ} \mathrm{C}\right) \delta 8.09(\mathrm{~s}, 1 \mathrm{H}), 7.93(\mathrm{~s}, 1 \mathrm{H}), 7.88(\mathrm{~s}, 2 \mathrm{H}), 7.83(\mathrm{~s}, 2 \mathrm{H})$, $6.41(\mathrm{~s}, 1 \mathrm{H}), 6.35(\mathrm{~s}, 2 \mathrm{H}), 4.59(\mathrm{bq}, J=114 \mathrm{~Hz}), 3.68(\mathrm{~s}, 3 \mathrm{H})$.

${ }^{11} \mathrm{~B}$ NMR $\left(225 \mathrm{MHz}, \mathrm{CD}_{3} \mathrm{CN}, 23^{\circ} \mathrm{C}\right) \delta-4.52(\mathrm{~d}, J=114 \mathrm{~Hz})$.

${ }^{13} \mathrm{C}$ NMR $\left(176 \mathrm{MHz}, \mathrm{CD}_{3} \mathrm{CN}, 23^{\circ} \mathrm{C}\right) \delta 143.81,141.79,136.11,135.92,114.57$ (q, J= 386 $\mathrm{Hz}) 106.34,105.87,44.37$ (sept, $J=5.4 \mathrm{~Hz}$ )

${ }^{19} \mathrm{~F}$ NMR $\left(471 \mathrm{MHz}, \mathrm{CD}_{3} \mathrm{CN}, 23{ }^{\circ} \mathrm{C}\right) \delta-23.44(\mathrm{~s})$.

Elemental analysis: calculated for $\mathrm{C}_{12} \mathrm{H}_{13} \mathrm{~N}_{6} \mathrm{BF}_{6} \mathrm{Ni}, \mathrm{C}: 33.93, \mathrm{H}: 3.08, \mathrm{~N}: 19.79$; Found: $\mathrm{C}$ : 34.28, H: 3.55, N: 19.66 
Comment on synthetic route to 6: Attempts to directly synthesize complex 6 via the direct reaction of $\left[\mathrm{TpNi}^{\prime \prime}\left(\mathrm{CF}_{3}\right)_{2}\right]^{-}$with $\mathrm{CH}_{3}$ l or $\mathrm{CH}_{3} \mathrm{OTf}$ resulted in $\mathrm{N}$-methylation of a pyrazole group on the ligand. We hypothesized that alternative synthetic routes based on consecutive $1 e^{-}$oxidations of nickel would avoid unwanted ligand methylation. A preliminary mechanistic proposal for the formation of $\mathbf{6}$ from aryl diazonium salts and methyl iodide is shown below. We propose that reduction of $\operatorname{ArN}_{2}{ }^{+}$by $\mathrm{NMe}_{4}\left[\mathrm{TpNi}^{\prime \prime}\left(\mathrm{CF}_{3}\right)_{2}\right]$ generates an aryl radical which then undergoes transiodination ${ }^{8}$ with $\mathrm{CH}_{3}$ l. The resulting methyl radical then adds to $\operatorname{TpNi}^{\text {III }}\left(\mathrm{CF}_{3}\right)_{2}$ to form 6 . Consistent with this hypothesis, $\mathrm{TpNi}^{\prime \prime \prime}\left(\mathrm{CF}_{3}\right)_{2}(\mathrm{MeCN})$ (1) was isolated in $5-20 \%$ yield when $\mathrm{MeCN}$ was added to the crude reaction mixture. The 2,6-difluorophenyl substitution pattern on the aryl diazonium was found to limit competitive addition of the aryl radical to the nickel center, while maintaining efficient transiodination with $\mathrm{CH}_{3}$ l. Accordingly, the use of the $4-\mathrm{F}_{-} \mathrm{C}_{6} \mathrm{H}_{4} \mathrm{~N}_{2}{ }^{+}$in place of 2,6F- $\mathrm{C}_{6} \mathrm{H}_{3} \mathrm{~N}_{2}{ }^{+}$resulted in mixtures of 2 and $\boldsymbol{6}$.

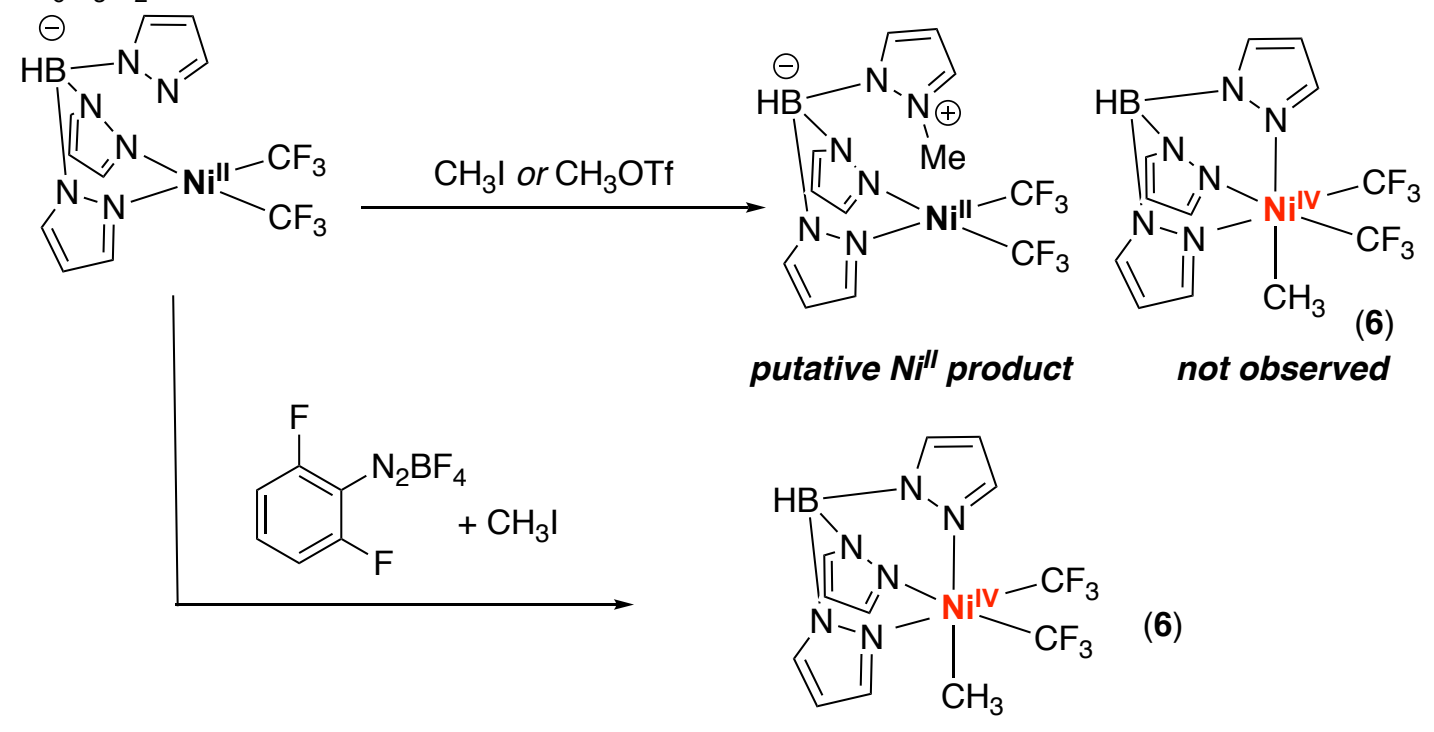

preliminary mechanistic proposal

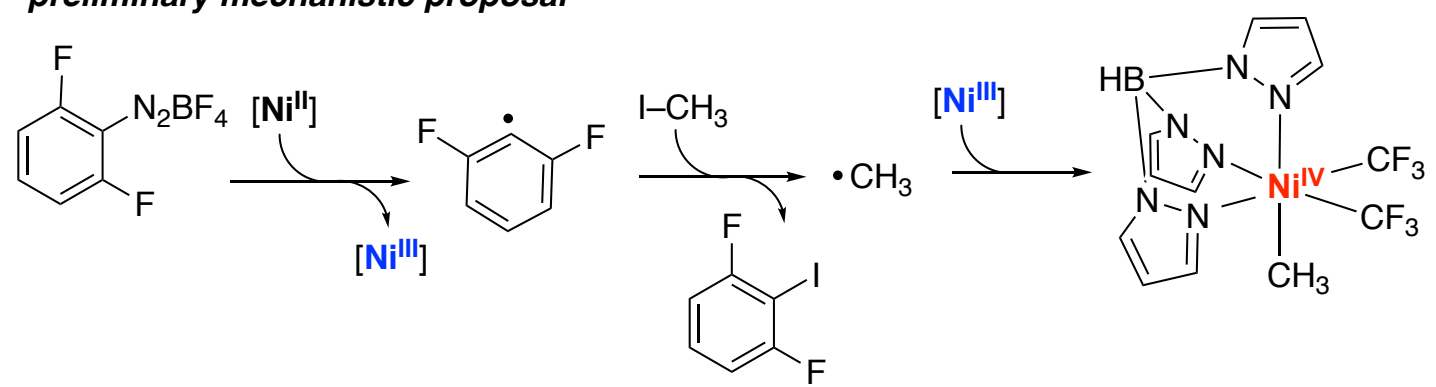




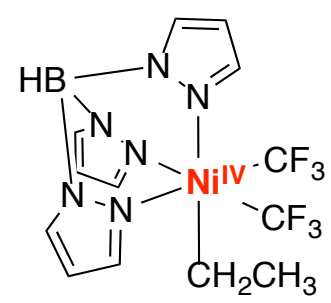

S2

Synthesis of $\mathrm{TpNi}^{\mathrm{IV}}\left(\mathrm{CF}_{3}\right)_{2}\left(\mathrm{CH}_{2} \mathrm{CH}_{3}\right)$ : A $20 \mathrm{~mL}$ vial was charged with $\mathrm{NMe}_{4} \mathrm{Tp}^{1}$ (309 mg, $1.08 \mathrm{mmol}, 1$ equiv), (MeCN) ${ }_{2} \mathrm{Ni}\left(\mathrm{CF}_{3}\right)_{2}{ }^{6}$ (300 mg, $1.08 \mathrm{mmol}, 1$ equiv), anhydrous $\mathrm{CH}_{3} \mathrm{NO}_{2}$ $(4.7 \mathrm{~mL})$, and a magnetic stir bar. The resulting solution was stirred for $1 \mathrm{~min}$, and then $\mathrm{CH}_{3} \mathrm{CH}_{2}$ ( $1.7 \mathrm{~mL}, 22 \mathrm{mmol}, 20$ equiv) was added in one portion. In a separate vial, 2,6difluorobenzene diazonium tetrafluoroborate $(319 \mathrm{mg}, 1.40 \mathrm{mmol}, 1.3$ equiv) was dissolved in $\mathrm{CH}_{3} \mathrm{NO}_{2}(2.5 \mathrm{~mL})$. Upon addition of the aryl diazonium solution to the solution of $\left[\mathrm{TpNi}\left(\mathrm{CF}_{3}\right)_{2}\right]^{-}$, the solutions immediately bubbled vigorously and turned dark brown. The vial was then removed from the drybox. Celite $(\sim 5 \mathrm{~mL})$ was added, and the mixture concentrated to give a suspension of crude product on celite. The mixture was dried under vacuum in the dark overnight $(\sim 14 \mathrm{~h})$. The crude product/celite mixture was loaded onto a silica gel column, and the product eluted with $2 \%$ EtOAc/hexanes. The volatiles were removed under vacuum to yield $\mathbf{S} 2$ as a yellow solid $(79 \mathrm{mg}, 17 \%$ yield).

${ }^{1} \mathrm{H}$ NMR $\left(500 \mathrm{MHz}, \mathrm{CD}_{3} \mathrm{CN}\right) \delta 7.97(\mathrm{~s}, 3 \mathrm{H}), 7.83(\mathrm{dd}, J=11.2,2.3 \mathrm{~Hz}, 3 \mathrm{H}), 6.33$ (dt, $J=$ 8.3, 2.3 Hz, 3H), 4.82 (q, $J=7.1 \mathrm{~Hz}, 2 \mathrm{H}), 4.61(\mathrm{bq}, J=117 \mathrm{~Hz}), 0.37(\mathrm{t}, J=7.1 \mathrm{~Hz}, 3 \mathrm{H}$ ).

${ }^{11} \mathrm{~B}$ NMR $\left(128 \mathrm{MHz}, \mathrm{CD}_{3} \mathrm{CN}\right) \delta-4.50(\mathrm{~d}, J=117 \mathrm{~Hz})$.

${ }^{13} \mathrm{C}$ NMR $\left(176 \mathrm{MHz}, \mathrm{CD}_{3} \mathrm{CN}\right) \delta 144.80-144.77(\mathrm{~m}), 143.64,136.94,136.59,115.47$ (q, $J=385.8 \mathrm{~Hz}$ ), 107.03, 106.5466 .72 (sept, $J=5.6 \mathrm{~Hz}$ ), 23.37.

${ }^{19} \mathrm{~F}$ NMR (470 MHz, $\left.\mathrm{CD}_{3} \mathrm{CN}\right) \delta-25.33(\mathrm{~s})$

Elemental analysis: calculated for $\mathrm{C}_{13} \mathrm{H}_{15} \mathrm{~N}_{6} \mathrm{BF}{ }_{6} \mathrm{Ni}, \mathrm{C} 35.38, \mathrm{H} 3.45, \mathrm{~N}$ 19.15; Found: C: 35.70, H: 3.33, N: 19.14 


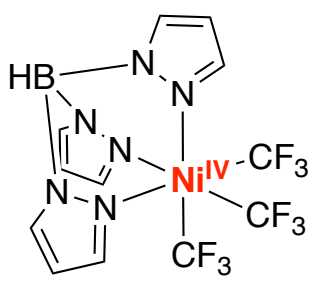

(7)

Synthesis of $\mathrm{TpNi}^{\mathrm{iV}}\left(\mathrm{CF}_{3}\right)_{3}$ 7: A $20 \mathrm{~mL}$ vial was charged with $\mathrm{NMe}_{4} \mathrm{TpNi}^{\mathrm{Il}}\left(\mathrm{CF}_{3}\right)_{2}(387 \mathrm{mg}$, $0.800 \mathrm{mmol}, 1.0$ equiv) and $\mathrm{CH}_{2} \mathrm{Cl}_{2}(10 \mathrm{~mL})$, and the resulting solution was cooled to -35 ${ }^{\circ} \mathrm{C}$. Solid 5-(trifluoromethyl)dibenzothiophenium trifluoromethanesulfonate (354 mg, 0.880 mmol, 1.1 equiv) was added in one portion to the vial, and the reaction mixture was stirred for 30 min while warming up to rt. The solution was filtered through a plug of Celite and concentrated in vacuo. Purification by column chromatography (elution gradient from 0$10 \%$ EtOAc in hexanes) yielded the product as a yellow microcrystalline solid (242 mg, $63 \%$ yield).

${ }^{1} \mathrm{H}$ NMR $\left(500 \mathrm{MHz}, \mathrm{CD}_{3} \mathrm{CN}, 23{ }^{\circ} \mathrm{C}\right) \delta 8.00(\mathrm{br}, 3 \mathrm{H}), 7.90(\mathrm{~d}, J=2.2 \mathrm{~Hz}, 3 \mathrm{H}), 6.39(\mathrm{t}, J=$ $2.2 \mathrm{~Hz}, 3 \mathrm{H}$ ), 4.58 (br. q, $J=118 \mathrm{~Hz}$ ).

${ }^{11} \mathrm{~B}$ NMR $\left(128 \mathrm{MHz}, \mathrm{CD}_{3} \mathrm{CN}, 23^{\circ} \mathrm{C}\right) \delta-4.55(\mathrm{~d}, J=118 \mathrm{~Hz})$.

${ }^{13} \mathrm{C}$ NMR $\left(126 \mathrm{MHz}, \mathrm{CD}_{3} \mathrm{CN}, 23{ }^{\circ} \mathrm{C}\right) \delta 145.3,137.6,110.3(\mathrm{q}, J=399 \mathrm{~Hz}), 107.4$.

${ }^{19} \mathrm{~F}$ NMR (471 $\left.\mathrm{MHz}, \mathrm{CD}_{3} \mathrm{CN}, 23{ }^{\circ} \mathrm{C}\right) \delta-19.39(\mathrm{~s}, 9 \mathrm{~F})$.

Elemental analysis calcd for $\mathrm{C}_{12} \mathrm{H}_{10} \mathrm{BF}_{9} \mathrm{~N}_{6} \mathrm{Ni}: \mathrm{C}, 30.11 ; \mathrm{H}, 2.11 ; \mathrm{N}, 17.55$. Found: $\mathrm{C}, 30.44$; $\mathrm{H}, 2.14 ; \mathrm{N}, 17.71$. 


\section{Radical Capture at $\mathrm{Ni}^{\text {'II }}$}

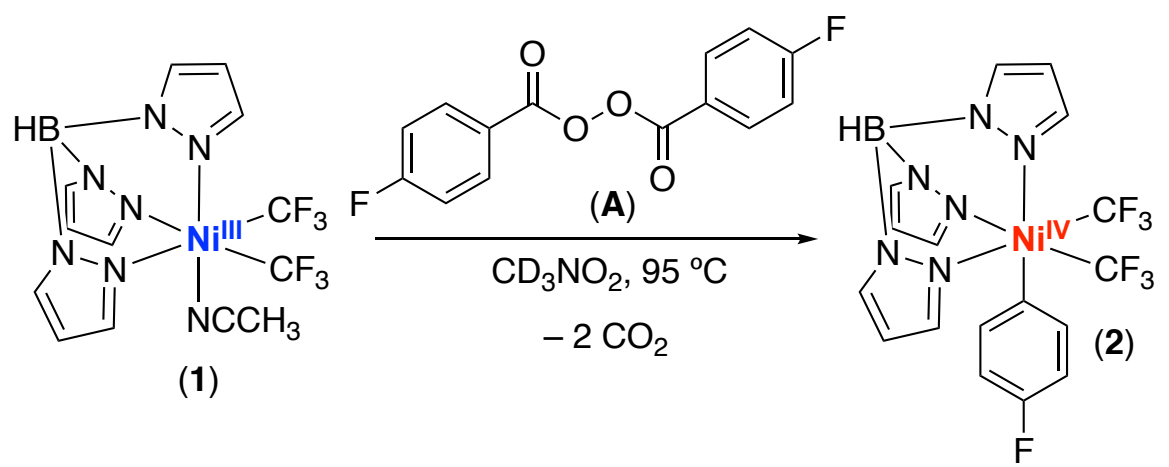

Reaction of 1 with A. A $4 \mathrm{~mL}$ vial was charged with 1 (4.8 mg, $0.011 \mathrm{mmol}, 1$ equiv), bis(4-fluorobenzoyl)peroxide (A, $14.6 \mathrm{mg}, 0.05 \mathrm{mmol}, 5$ equiv), and $\mathrm{C}_{6} \mathrm{~F}_{6}$ as a stock solution in $\mathrm{CD}_{3} \mathrm{NO}_{2}(0.015 \mathrm{M}, 0.7 \mathrm{~mL}, 1$ equiv). The vial was capped and then shaken to mix the contents. Once homogeneous, the solution was transferred to a J. Young NMR tube and removed from the glovebox. The sample was inserted into a preheated $\left(95^{\circ} \mathrm{C}\right) \mathrm{NMR}$ spectrometer, and the formation of 2 was monitored by ${ }^{19} \mathrm{~F}$ NMR over $15 \mathrm{~min}$. The yield peaked at $\sim 3 \%$ after 6 min of heating (Figure S1). After this point, the concentration of 2 rapidly decreased until it was not detectable. At the end of the reaction ( $t=15 \mathrm{~min}) 1$ was fully consumed as determined by ${ }^{11} \mathrm{~B}$ NMR. We attribute the low yield to the competitive decomposition of $\mathbf{1}$ and of the product $\mathbf{2}$, which was found to be rapid at the reaction temperature.

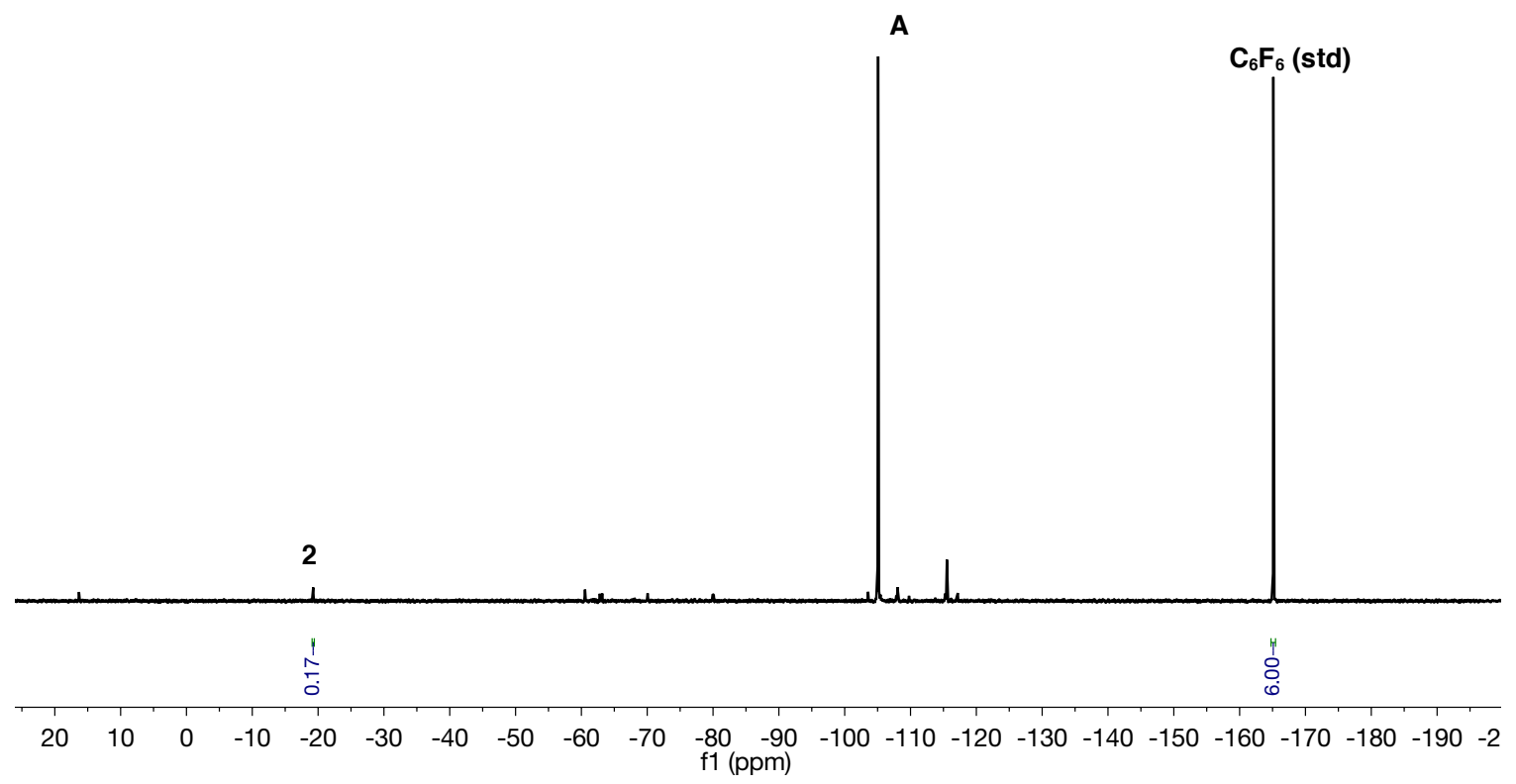

Figure S1. Crude ${ }^{19} \mathrm{~F}$ NMR spectrum of the reaction of $\mathbf{A}$ with 1 at $95^{\circ} \mathrm{C}$ in $\mathrm{CD}_{3} \mathrm{NO}_{2}$ after 6 min. 
<smiles></smiles>

(3)

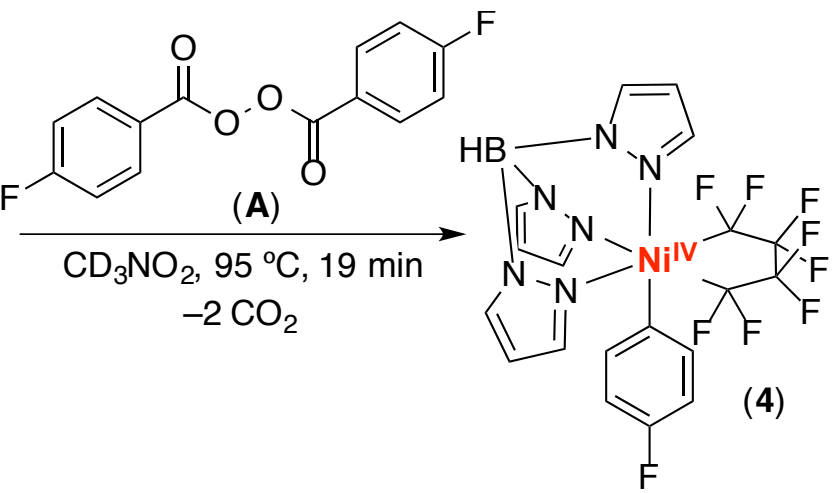

(4)

Reaction of 3 with A. A $4 \mathrm{~mL}$ vial was charged with 3 (5.0 mg, $0.010 \mathrm{mmol}, 1$ equiv), bis(4-fluorobenzoyl)peroxide $(A)$, and $\mathrm{C}_{6} \mathrm{~F}_{6}$ as a stock solution in $\mathrm{CD}_{3} \mathrm{NO}_{2}(0.014 \mathrm{M}, 0.7 \mathrm{~mL}$, 1 equiv). This solution was shaken and then transferred into a thick-walled J. Young NMR tube. The sample was inserted into a preheated $\left(95^{\circ} \mathrm{C}\right) \mathrm{NMR}$ spectrometer, and the formation of 4 was monitored by ${ }^{19} \mathrm{~F}$ NMR over approximately $35 \mathrm{~min}$. As shown in Figure $\mathrm{S} 2$, increasing the equiv of $\mathbf{A}$ (from 1 equiv to 18 equiv) resulted in higher yields. Additional heating eventually resulted in decomposition of 4 into a complex mixture of nickelcontaining products. At the maximum yield of 4 (using 18 equiv of $\mathbf{A}$ and heating for 19 min), A was only $\sim 11 \%$ consumed as determined by ${ }^{19} \mathrm{~F}$ NMR spectroscopy. Representative ${ }^{19}$ F NMR spectra are shown in Figure S3.

Notably, at early time points the competitive formation of a new $\mathrm{Ni}^{\mathrm{lV}}$ complex, later identified as Int-1, can be observed by ${ }^{19} \mathrm{~F}$ NMR spectroscopy. The concentration of Int-1 peaks at $\mathrm{t}=5 \mathrm{~min}$, after which it quickly decreases and becomes undetectable. As described in detail below, studies on the thermolysis of Int-1 suggest that it is not an intermediate in the formation of 4.

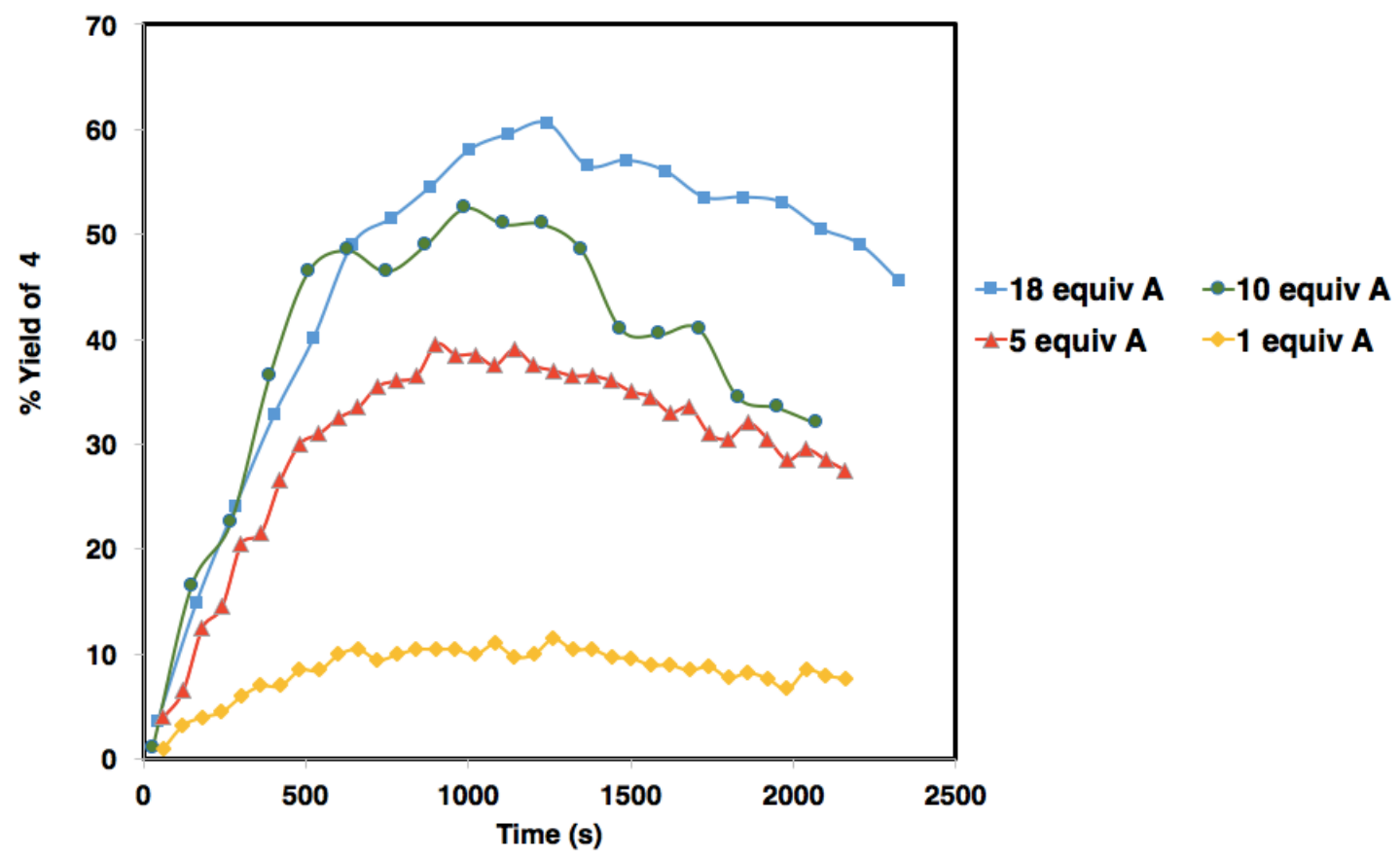

Figure S2. Time studies of the formation and decomposition of $\mathbf{4}$ during the reaction of $\mathbf{A}$ with 3 at $95^{\circ} \mathrm{C}$ in $\mathrm{CD}_{3} \mathrm{NO}_{2}$. 

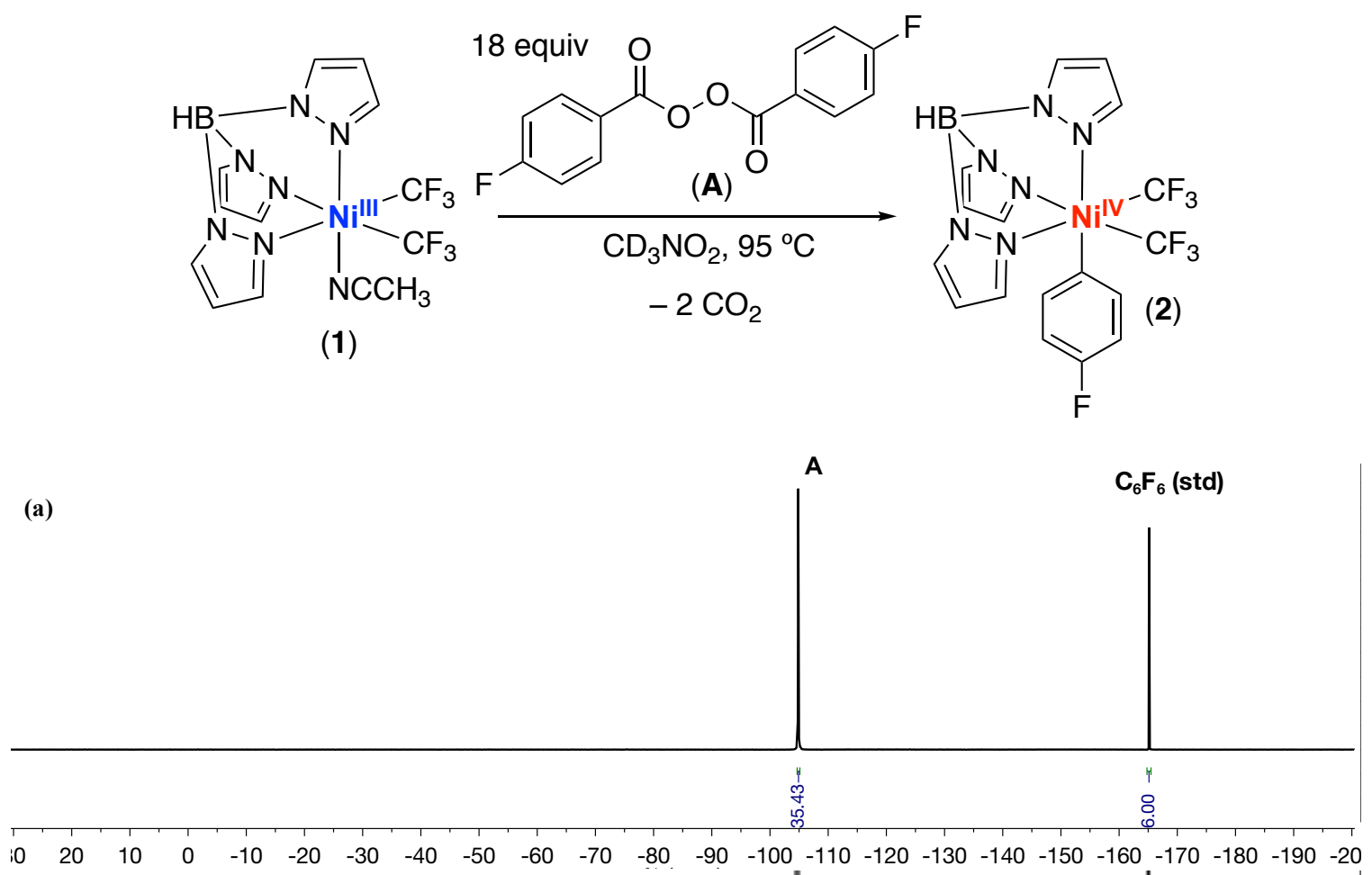

(b)

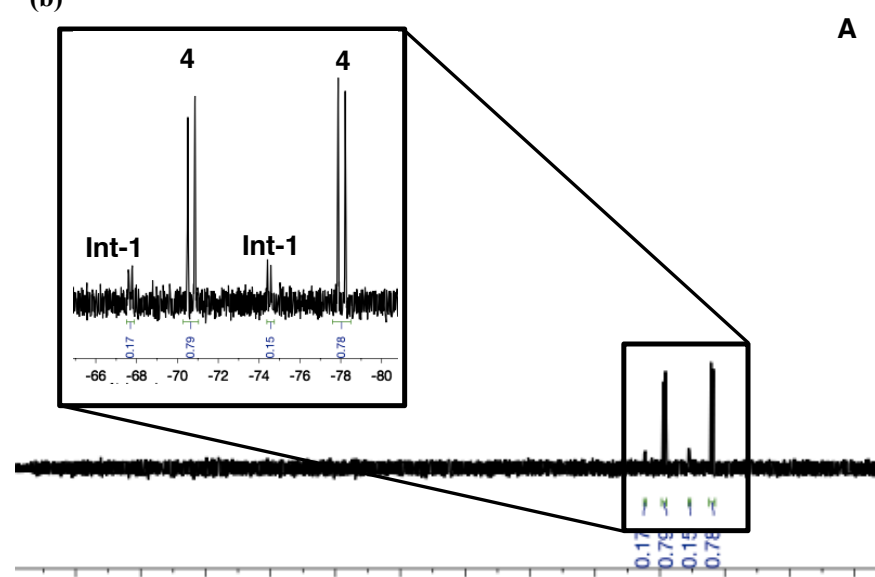

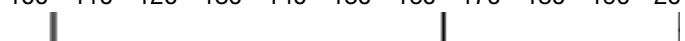

A

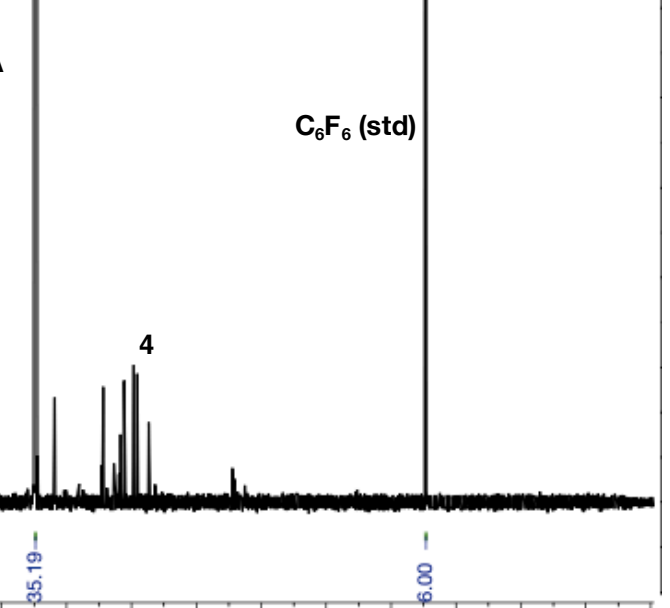

(c)

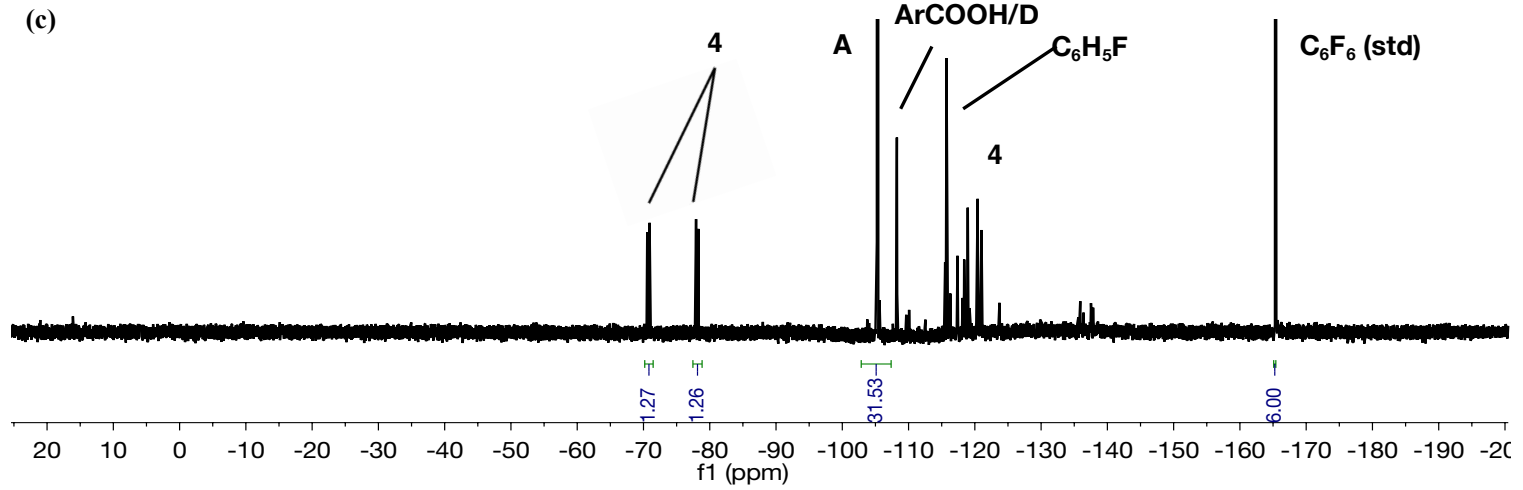




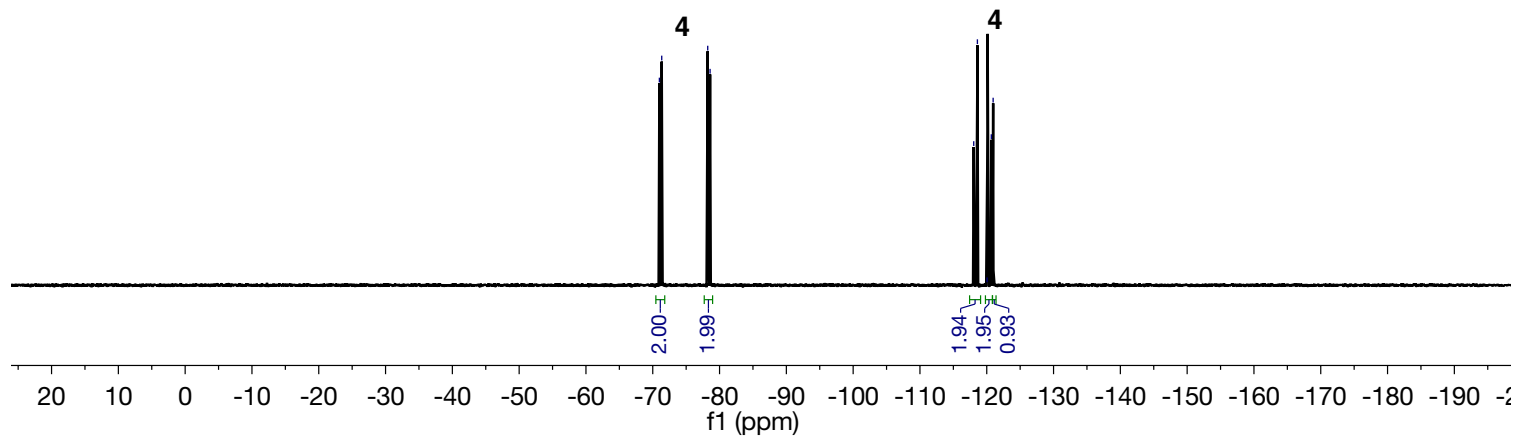

Figure S3. (a) ${ }^{19} \mathrm{~F}$ NMR spectrum of $\mathbf{3}$ and $\mathbf{A}$ before heating. (b) ${ }^{19} \mathrm{~F}$ NMR spectrum of the crude reaction between $\mathbf{3}$ and $\mathbf{A}$ at $95{ }^{\circ} \mathrm{C}$ in $\mathrm{CD}_{3} \mathrm{NO}_{2}$ after $5 \mathrm{~min}$ and (c) $19 \mathrm{~min}$. (d) ${ }^{19} \mathrm{~F}$ NMR spectrum of 4 . Intense resonances are truncated for clarity. 


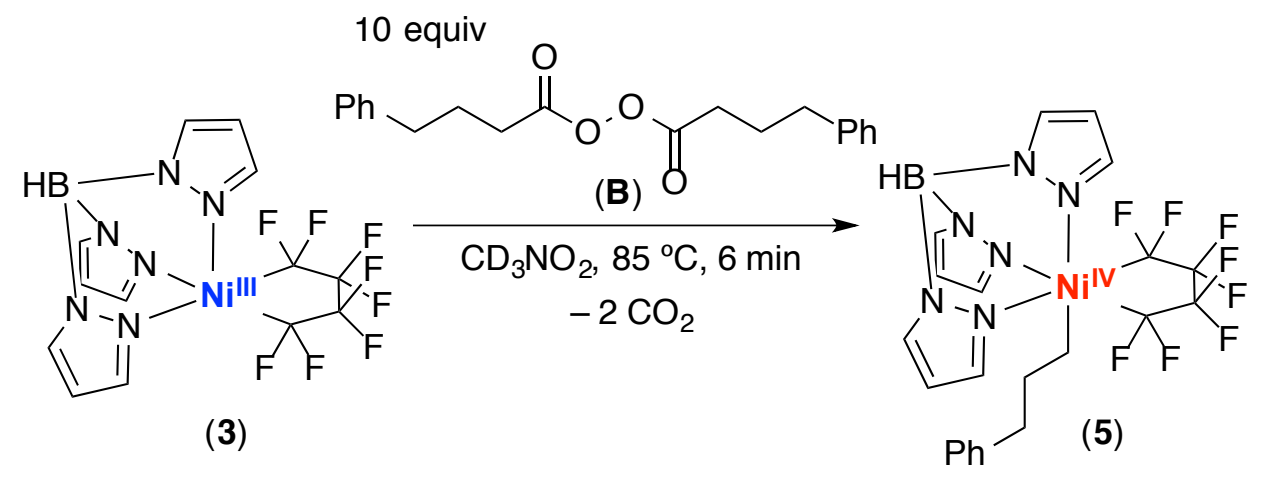

Reaction of 3 with B. A $4 \mathrm{~mL}$ vial was charged with $3(5.0 \mathrm{mg}, 0.011 \mathrm{mmol}, 1$ equiv), bis(4-phenylbutryl)peroxide ( $B, 32 \mathrm{mg}, 0.11 \mathrm{mmol}, 10$ equiv), and $\mathrm{C}_{6} \mathrm{~F}_{6}$ as a stock solution in $\mathrm{CD}_{3} \mathrm{NO}_{2}(0.015 \mathrm{M}, 0.7 \mathrm{~mL}, 1$ equiv). This solution was shaken and then transferred into a thick-walled J. Young NMR tube. The sample was inserted into a preheated $\left(85^{\circ} \mathrm{C}\right)$ NMR spectrometer, and the formation of $\mathbf{5}$ was monitored by ${ }^{19} \mathrm{~F}$ NMR spectroscopy for $30 \mathrm{~min}$. The maximum yield of 5 was observed at $6 \mathrm{~min}$, after which point the resonances associated with 5 decreased. A representative ${ }^{19} \mathrm{~F}$ NMR spectrum of the crude reaction mixture is shown in Figure S4.

(a)

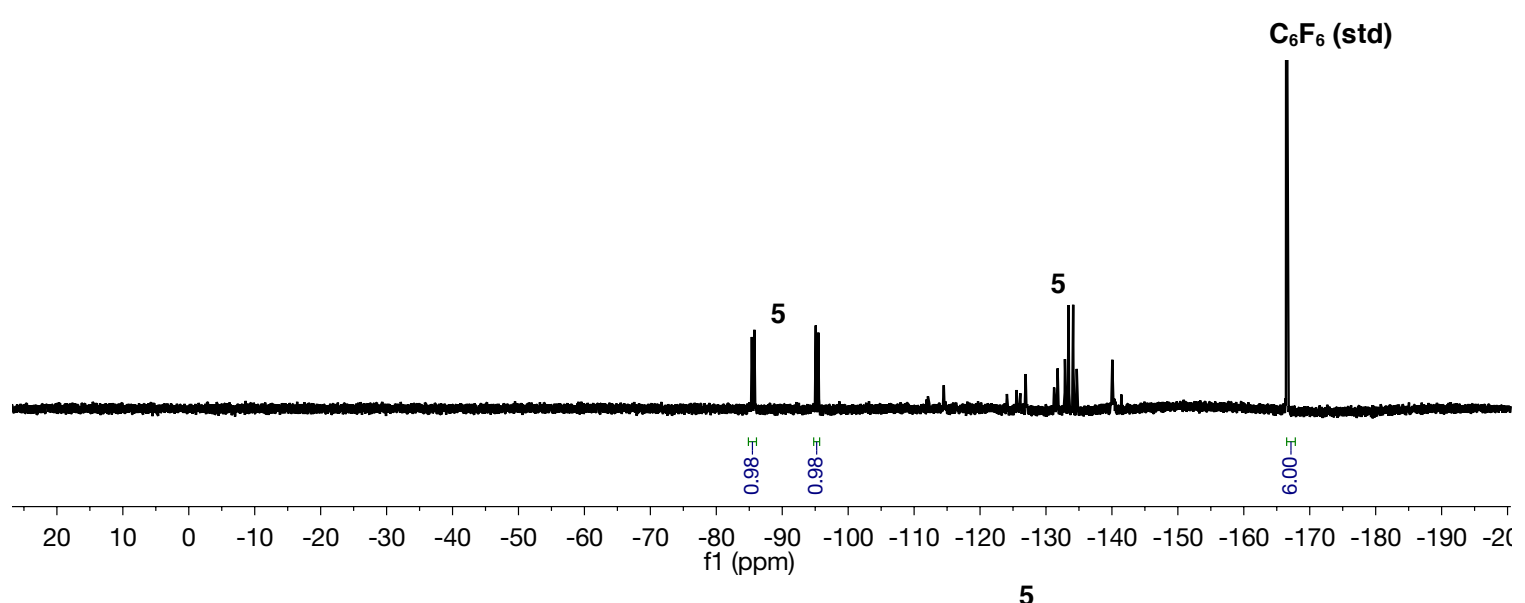

(b)

5

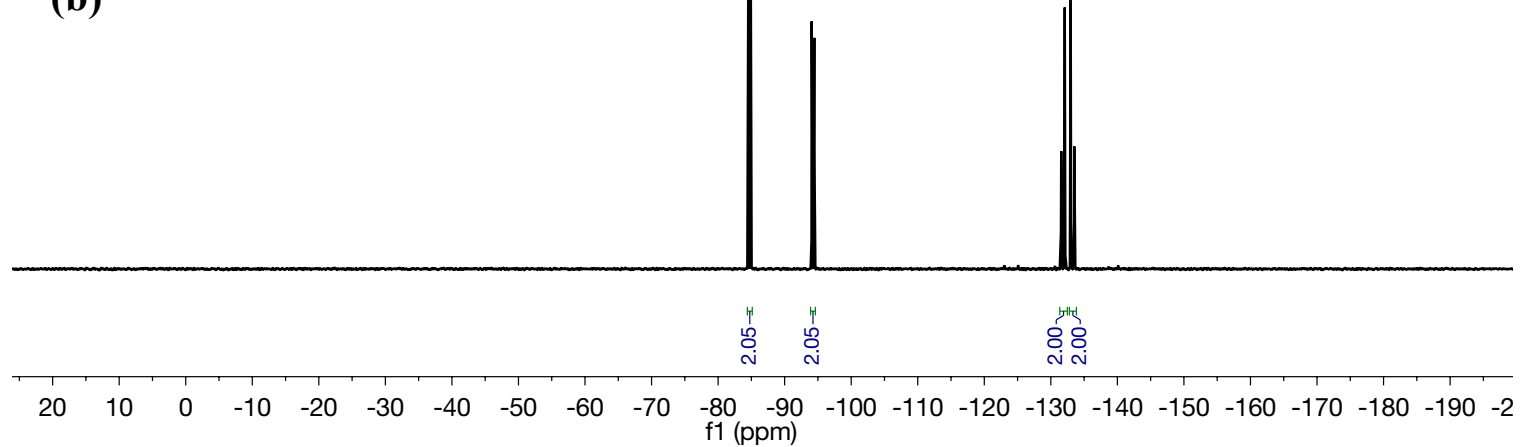

Figure S4. (a) ${ }^{19} \mathrm{~F}$ NMR spectrum of the crude reaction between $\mathbf{3}$ and $\mathbf{B}$ at $85{ }^{\circ} \mathrm{C}$ in $\mathrm{CD}_{3} \mathrm{NO}_{2}$ after 6 min. (b) ${ }^{19} \mathrm{~F}$ NMR spectrum of 5 . Intense resonances are truncated for clarity. 


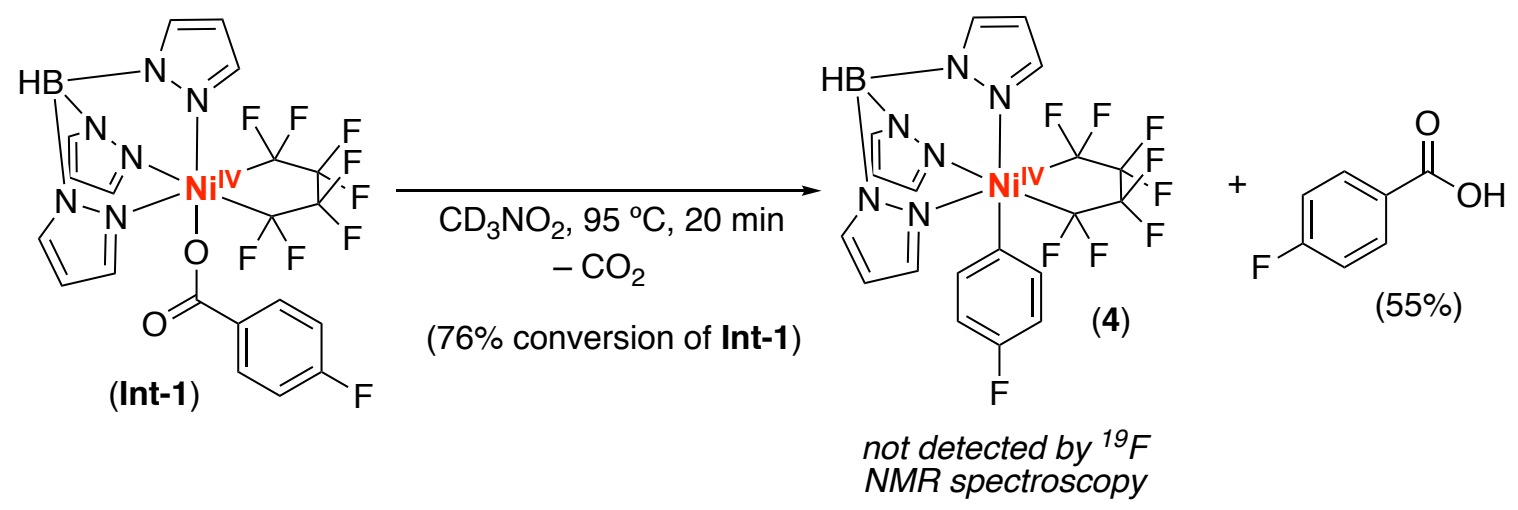

Thermolysis of Int-1. To a $4 \mathrm{~mL}$ scintillation vial was added Int-1 $(4 \mathrm{mg}, 0.007$ $\mathrm{mmol})$ and $\mathrm{CD}_{3} \mathrm{NO}_{2}(0.47 \mathrm{~mL}, 0.014 \mathrm{M})$, along with $\mathrm{C}_{6} \mathrm{~F}_{6}$ as an internal standard. The vial was agitated until the mixture was homogeneous. The solution was transferred to a thick-walled J. Young NMR tube. A ${ }^{19} \mathrm{~F}$ NMR spectrum was acquired at $25^{\circ} \mathrm{C}$ prior to heating to obtain the initial $\mathrm{C}_{6} \mathrm{~F}_{6}$ to Int-1 ratio. The NMR probe was heated to $95^{\circ} \mathrm{C}$, using a sample containing $\mathrm{CD}_{3} \mathrm{NO}_{2}$ and $\mathrm{C}_{6} \mathrm{~F}_{6}$ to shim the instrument. Immediately after shimming, the J. Young NMR tube containing Int-1 was inserted into the NMR probe, and spectra were collected every 2 min for $20 \mathrm{~min}$. No evidence for the formation of $\mathbf{4}$ was observed by ${ }^{19} \mathrm{~F} \mathrm{NMR}$ spectroscopy throughout the course of the experiment. After $20 \mathrm{~min}, 76 \%$ of Int-1 was consumed, and 4 -fluorobenzoic acid was observed in $55 \%$ yield relative to the initial concentration of Int-1. This experiment strongly suggests that decarboxylation of Int-1 is not responsible for the formation of $\mathbf{4}$ during the reaction between $\mathrm{A}$ and 3 . Crude ${ }^{19} \mathrm{~F}$ NMR spectra of the first and final time points are shown in Figure S5. 
(a)

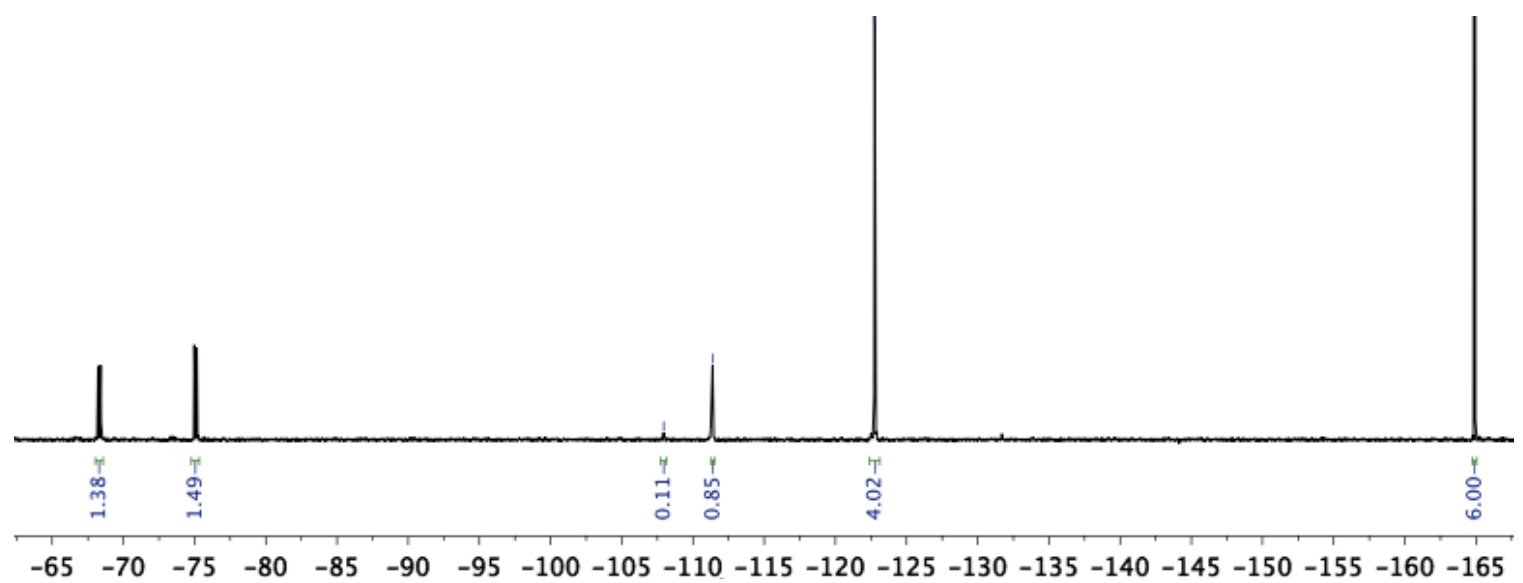

(b)

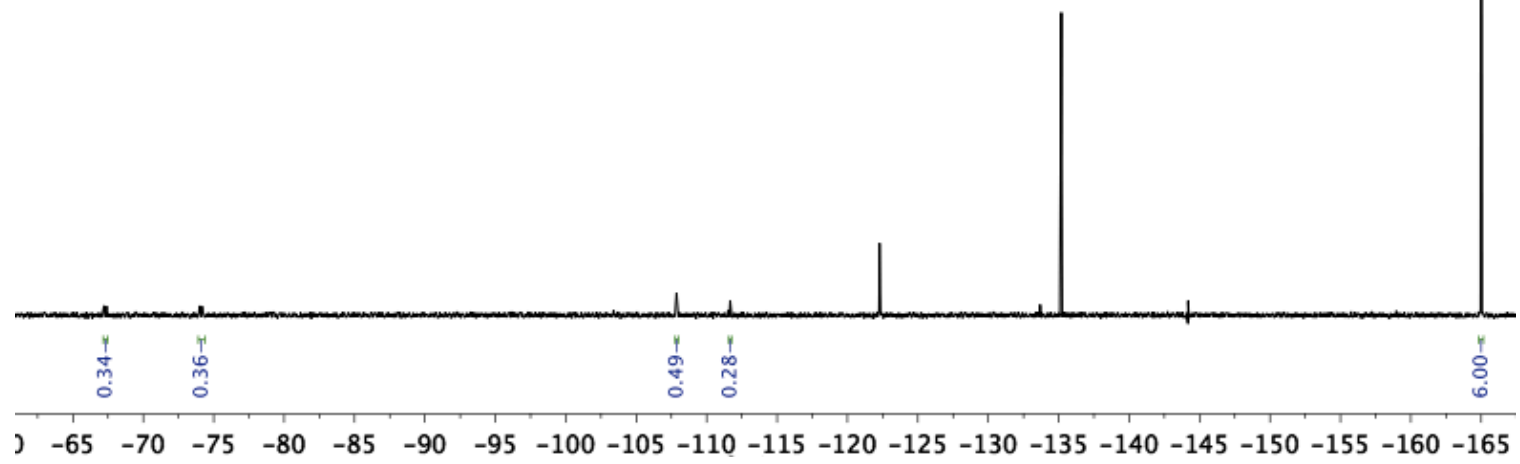

Figure S5. ${ }^{19} \mathrm{~F}$ NMR spectrum of Int-1 (a) before heating and (b) after heating at $95^{\circ} \mathrm{C}$ for 20 min in $\mathrm{CD}_{3} \mathrm{NO}_{2}$. 
<smiles>O=[N+]([O-])/C=C/[PH+]([O-])[O-]</smiles>

(3)

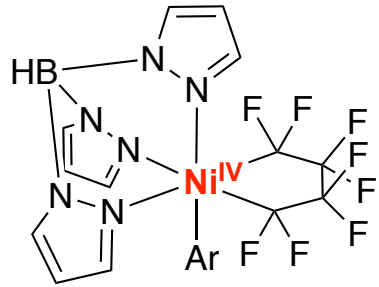

(4)

Aryl radical scavenging experiments. A $4 \mathrm{~mL}$ vial was charged with $3(5.0 \mathrm{mg}, 0.010$ mmol, 1 equiv), 20 equiv $\beta$-nitrostyrene, bis-(4-fluorobenzoyl)peroxide ( $\mathbf{A}, 53 \mathrm{mg}, 0.019$, 18 equiv), and $\mathrm{C}_{6} \mathrm{~F}_{6}$ as a stock solution in $\mathrm{CD}_{3} \mathrm{NO}_{2}(0.015 \mathrm{M}, 0.7 \mathrm{~mL}, 1$ equiv). This resulting solution was shaken and then transferred into a thick-walled J. Young NMR tube. The sample was inserted into a preheated $\left(95^{\circ} \mathrm{C}\right)$ oil bath for 19 min before it was removed, submerged in a $23{ }^{\circ} \mathrm{C}$ water bath, and then analyzed by ${ }^{19} \mathrm{~F}$ NMR spectroscopy. The yield of $4(19 \%)$ was significantly lower than that obtained in the absence of the $\beta$-nitrostyrene $(61 \%)$ under otherwise analogous conditions. A representative ${ }^{19} \mathrm{~F} N \mathrm{NR}$ spectrum at $\mathrm{t}=$ 19 min is shown in Figure S6.

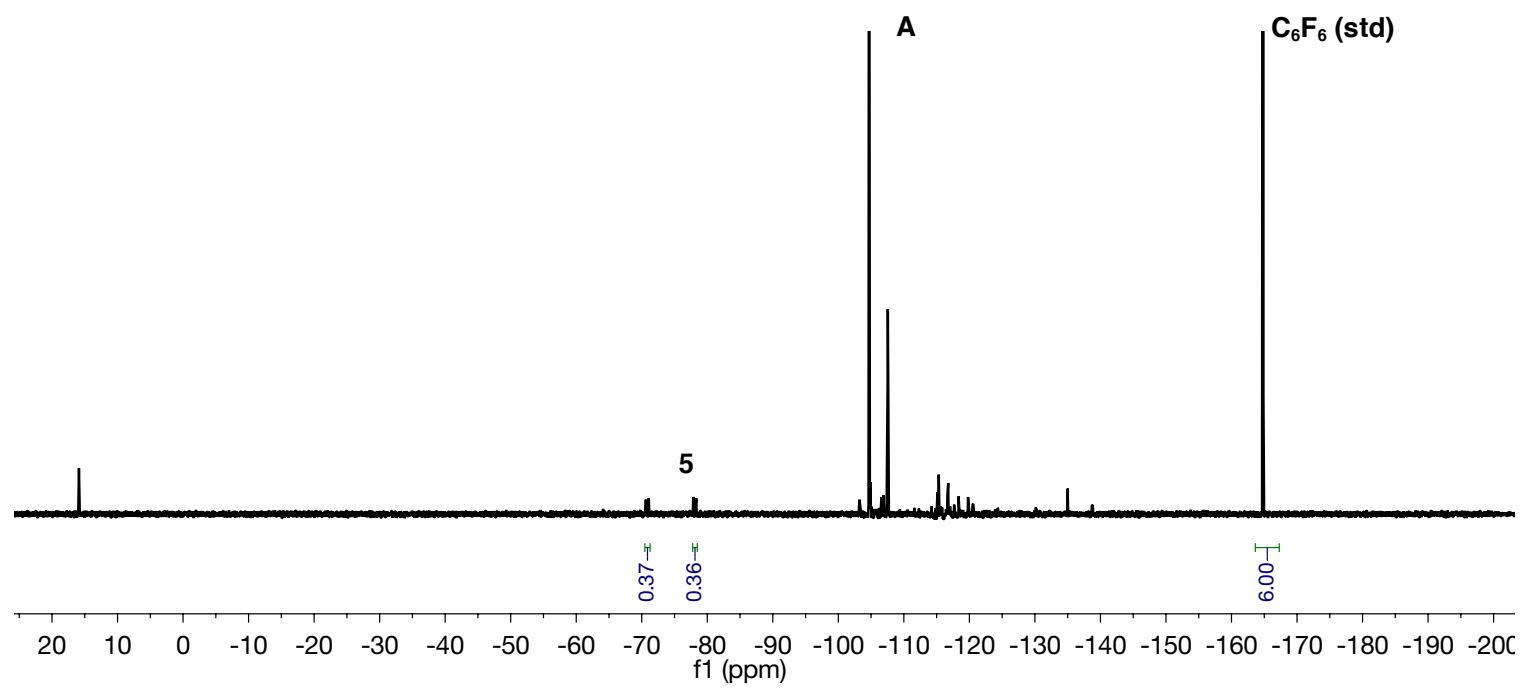

Figure S6. Crude ${ }^{19} \mathrm{~F}$ NMR spectrum of the reaction of $\mathbf{3}$ with $\mathbf{A}$ in the presence of 20 equiv of $\beta$-nitrostyrene after heating at $95^{\circ} \mathrm{C}$ for $19 \min$ in $\mathrm{CD}_{3} \mathrm{NO}_{2}$. 


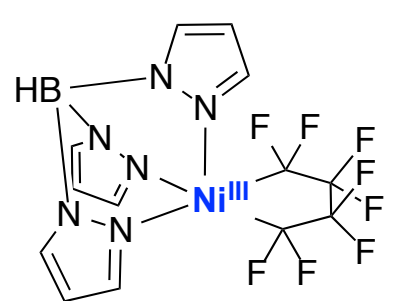

(3)

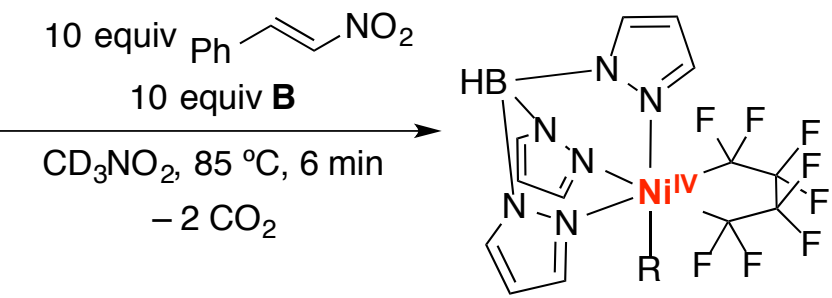

(5)

Alkyl radical scavenging experiments. A $4 \mathrm{~mL}$ vial was charged with $3(5.0 \mathrm{mg}, 0.010$ mmol, 1 equiv), 10 equiv $\beta$-nitrostyrene, bis-(4-phenylbutyryl)peroxide $(B, 31 \mathrm{mg}, 0.019$, 10 equiv), and $\mathrm{C}_{6} \mathrm{~F}_{6}$ as a stock solution in $\mathrm{CD}_{3} \mathrm{NO}_{2}(0.014 \mathrm{M}, 0.7 \mathrm{~mL}, 1$ equiv). This solution was capped, shaken, and transferred into a thick-walled J. Young tube. The sample was wrapped in aluminum foil to exclude light, and inserted into a preheated $\left(85^{\circ} \mathrm{C}\right)$ oil bath for 6 min before it was removed, immediately cooled in a $23^{\circ} \mathrm{C}$ water bath, and then analyzed by ${ }^{19} \mathrm{~F}$ NMR spectroscopy. The yield of $5(14 \%)$ was significantly lower than that obtained in the absence of the $\beta$-nitrostyrene $(49 \%)$ under otherwise analogous conditions. A representative ${ }^{19} \mathrm{~F}$ NMR spectrum at $\mathrm{t}=6 \mathrm{~min}$ is shown in Figure $\mathrm{S} 7$.

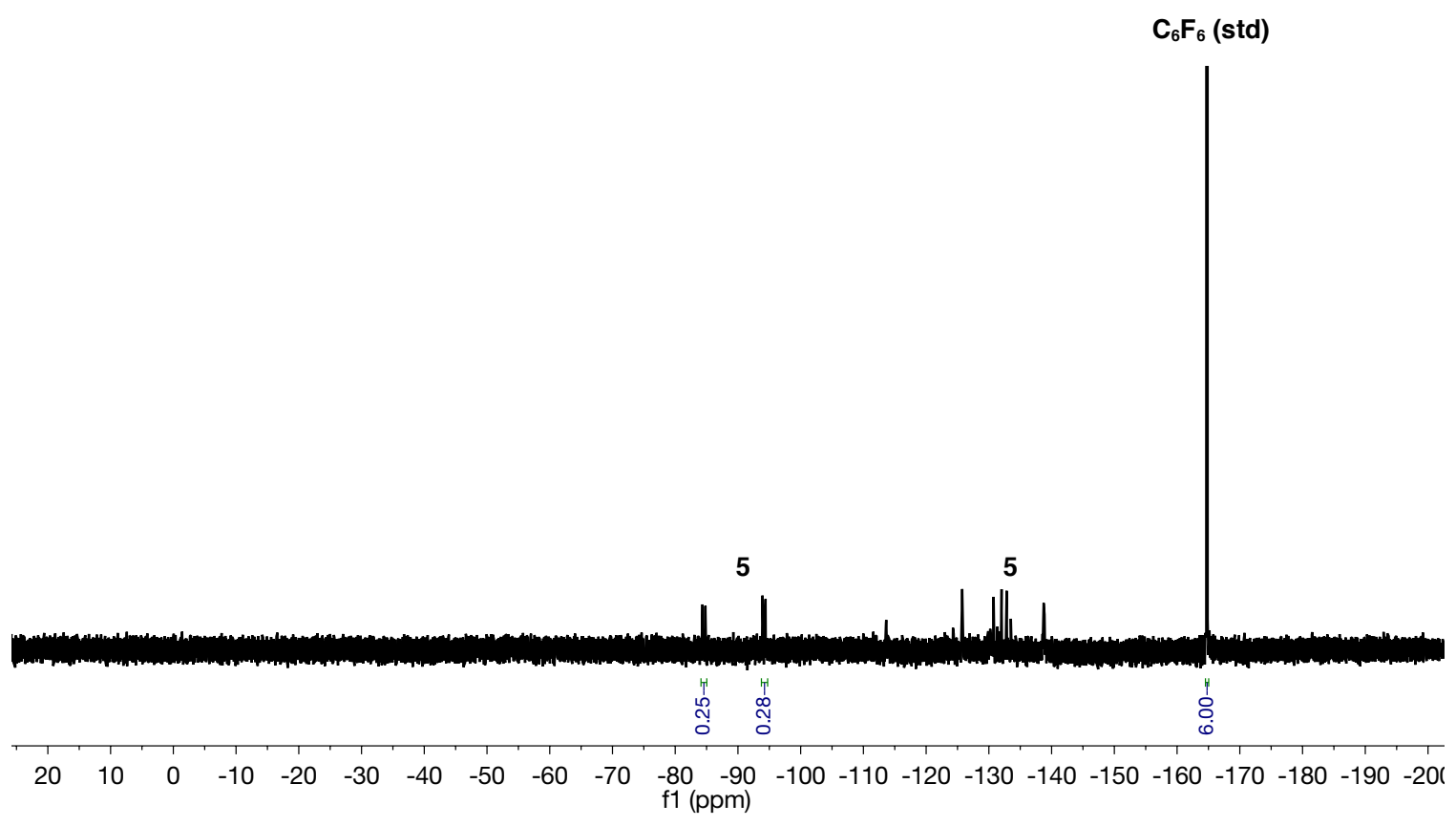

Figure S7. Crude ${ }^{19} \mathrm{~F}$ NMR spectrum of the reaction of the reaction of $\mathbf{3}$ with $\mathbf{A}$ in the presence of 20 equiv of $\beta$-nitrostyrene after heating at $85^{\circ} \mathrm{C}$ for 6 min in $\mathrm{CD}_{3} \mathrm{NO}_{2}$. Intense resonances are truncated for clarity. 
<smiles></smiles>

(1)

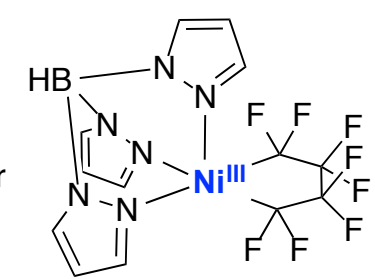

(3)

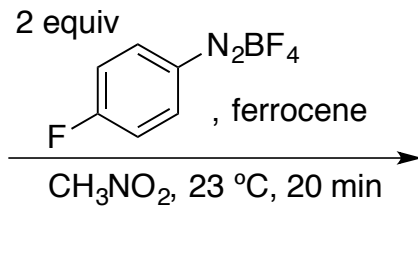

Radical generation using aryldiazonium and ferrocene. A $4 \mathrm{~mL}$ vial was charged with 1 or 3 ( $0.010 \mathrm{mmol}, 1$ equiv), 4-fluorophenyldiazonium tetrafluoroborate (4.2 $\mathrm{mg}, 0.020$, 2 equiv) and 4-fluoroanisole as a stock solution in $\mathrm{CH}_{3} \mathrm{NO}_{2}(0.12 \mathrm{M}, 0.5 \mathrm{~mL}, 6$ equiv). The solution was then shaken and transferred to a J. Young NMR tube. Analysis by ${ }^{19} \mathrm{~F} \mathrm{NMR}$ spectroscopy shows that 1 and 3 and $\mathrm{ArN}_{2} \mathrm{BF}_{4}$ do not react over the course of $1 \mathrm{~h}$. The NMR tube was brought back in to the glove box and was transferred back to the $4 \mathrm{~mL}$ vial and a magnetic stir bar was added. A separate $4 \mathrm{~mL}$ vial was charged with ferrocene (3.7 $\mathrm{mg}, 0.020 \mathrm{mmol}, 2$ equiv) and $\mathrm{CH}_{3} \mathrm{NO}_{2}(0.5 \mathrm{~mL})$. The solution of $\mathrm{Fc}$ was added dropwise to a rapidly stirring solution of 3 and $\mathrm{ArN}_{2} \mathrm{BF}_{4}$. Upon addition, the solution rapidly changed color from green to brown/black. The reaction mixture was transferred to a J. Young NMR tube. A representative ${ }^{19} \mathrm{~F}$ NMR spectrum of the reaction $20 \mathrm{~min}$ after the addition of ferrocene is shown in Figure S8. Compound 2 and 4 are formed in $52 \%$ and $72 \%$ yield respectively under these conditions. A representative spectrum from the reaction of $\mathbf{3}$ with ferrocene and 4-fluorophenyldiazonium tetrafluoroborate is shown below.

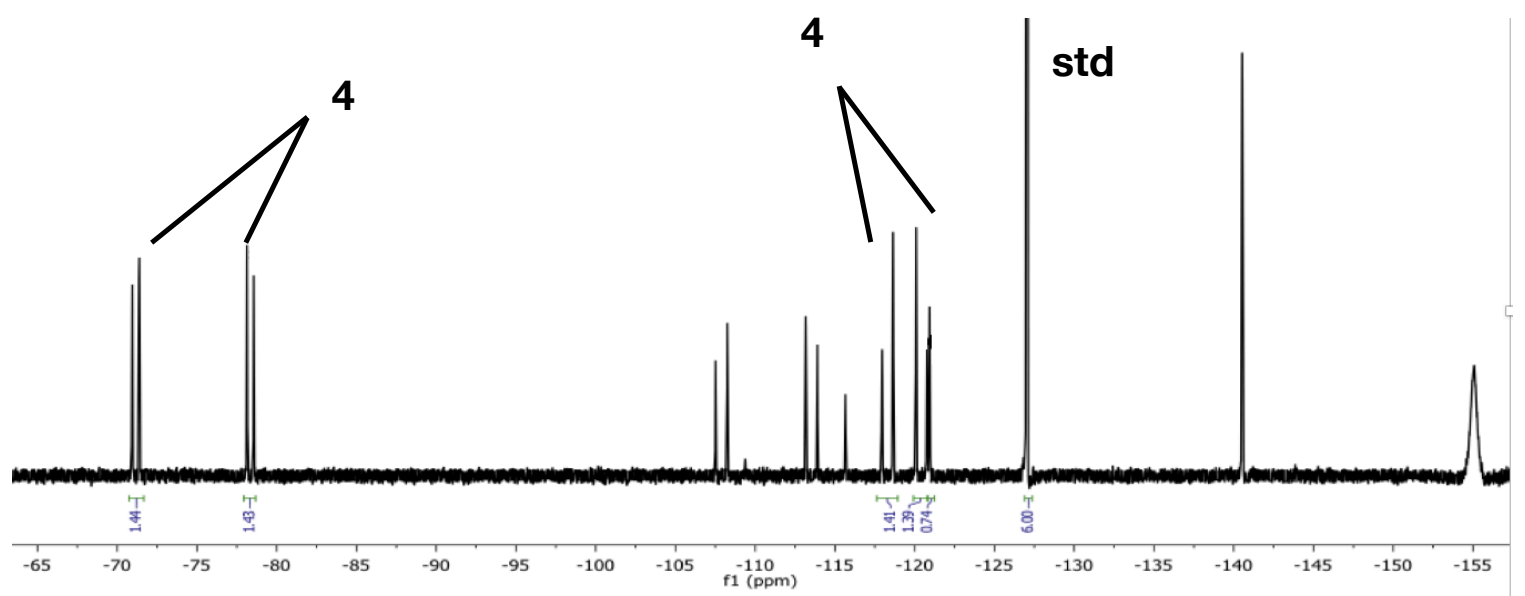

Figure S8. Crude ${ }^{19} \mathrm{~F}$ NMR spectrum of the reaction between $3, \mathrm{ArN}_{2} \mathrm{BF}_{4}$, and ferrocene. Intense resonances are truncated for clarity. 


\section{Radical C-C Coupling}

\section{Screening of $\operatorname{TpNi}^{\mathrm{lV}}\left(\mathbf{R}_{\mathrm{f}}\right)($ alkyl) complexes for radical $\mathrm{C}-\mathrm{C}$ coupling:}

Alkyl complex $\mathbf{5}$ was initially considered for studies of outer-sphere radical $\mathbf{C}-\mathrm{C}$ coupling at $\mathrm{Ni}^{\mathrm{iV}}$. However, $\mathbf{5}$ is not sufficiently thermally stable, decomposing upon thermolysis in the presence or absence of peroxides to afford the apparent $\beta$-hydride elimination product allyl benzene.

We hypothesized that the methyl analog, complex $\mathbf{S 1}$, would prove more stable. However, the isolation of pure $\mathbf{S 1}$ via the same route used to prepare $\mathbf{6}$ proved challenging due to competing decomposition of the title compound.

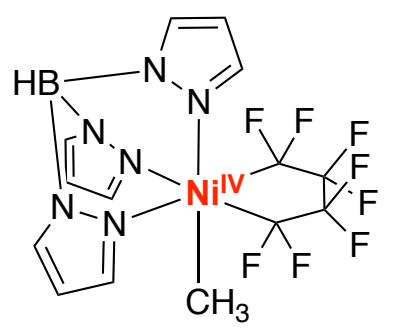

Compounds $\mathbf{6}$ and $\mathbf{S 2}$ were next prepared via the procedure on p. S9-S11 using $\mathrm{CH}_{3} \mathrm{I}$ and Etl, respectively. As is described below, compound $\mathbf{S} 2$ was found to rapidly decompose upon thermolysis at $90^{\circ} \mathrm{C}$, thereby precluding radical coupling studies with peroxide radical sources. Thus, 6 was selected as the model compound moving forward.<smiles></smiles>

6<smiles></smiles>

S2 


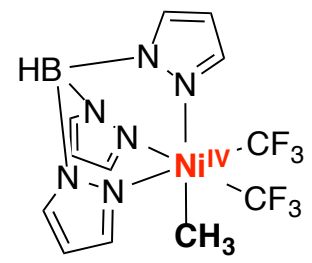

(6)<smiles>O=C(OOC(=O)c1ccc(F)cc1)c1ccc(F)cc1</smiles><smiles>Cc1ccc(F)c(S(=O)(=O)O[Na])c1</smiles><smiles>O=C(O)c1ccc(F)cc1</smiles>

$(40 \%)$

$(44 \%$ conversion of $\mathbf{A})$<smiles>Oc1ccc([18OH])cc1</smiles><smiles>Fc1ccc(-c2ccc(F)cc2)cc1</smiles>

Reaction of 6 with A. A $4 \mathrm{~mL}$ vial was charged with $\mathrm{TpNi}^{\mathrm{IV}}\left(\mathrm{CF}_{3}\right)_{2}\left(\mathrm{CH}_{3}\right)(\mathbf{6}, 4.7 \mathrm{mg}, 0.011$ mmol, 1 equiv), bis(4-fluorobenzoyl)peroxide (A, $9.4 \mathrm{mg}, 3$ equiv, $0.034 \mathrm{mmol}$ ), and 0.7 $\mathrm{mL}$ of $\mathrm{CD}_{3} \mathrm{NO}_{2}$ containing $\mathrm{C}_{6} \mathrm{~F}_{6}(\sim 0.03 \mathrm{M})$ as an internal standard, and the vial was capped and shaken. The solution was then transferred to a thick-walled J. Young tube. A ${ }^{19} \mathrm{~F}$ NMR spectrum was recorded to determine the exact ratio between 6 and internal standard. The $J$. Young NMR tube was then covered in aluminum foil to exclude light and placed in a preheated oil bath at $90^{\circ} \mathrm{C}$ for $60 \mathrm{~min}$. The tube was removed from the oil bath and allowed to cool to room temperature. The crude reaction was analyzed by ${ }^{19} \mathrm{~F}$ spectroscopy to determine the yields of the organic products. The identities of 4-fluorotoluene, fluorobenzene, 4,4'-difluorobiphenyl, and 4-fluorobenzoic acid were confirmed by comparison to authentic samples. The high ratio of 4-fluorotoluene relative to homocoupled C-C products, 4,4'-difluorobiphenyl and ethane (maximum theoretical yield of $17 \%$ ), suggests that neither $\cdot \mathrm{CH}_{3}$ nor $\cdot \mathrm{Ar}$ are present in high concentration throughout the reaction. All listed yields are relative to initial concentration of $\left[\mathrm{Ni}^{\mathrm{iV}}\right]$ complex. Representative NMR spectra are shown in Figure S9. 
(a)

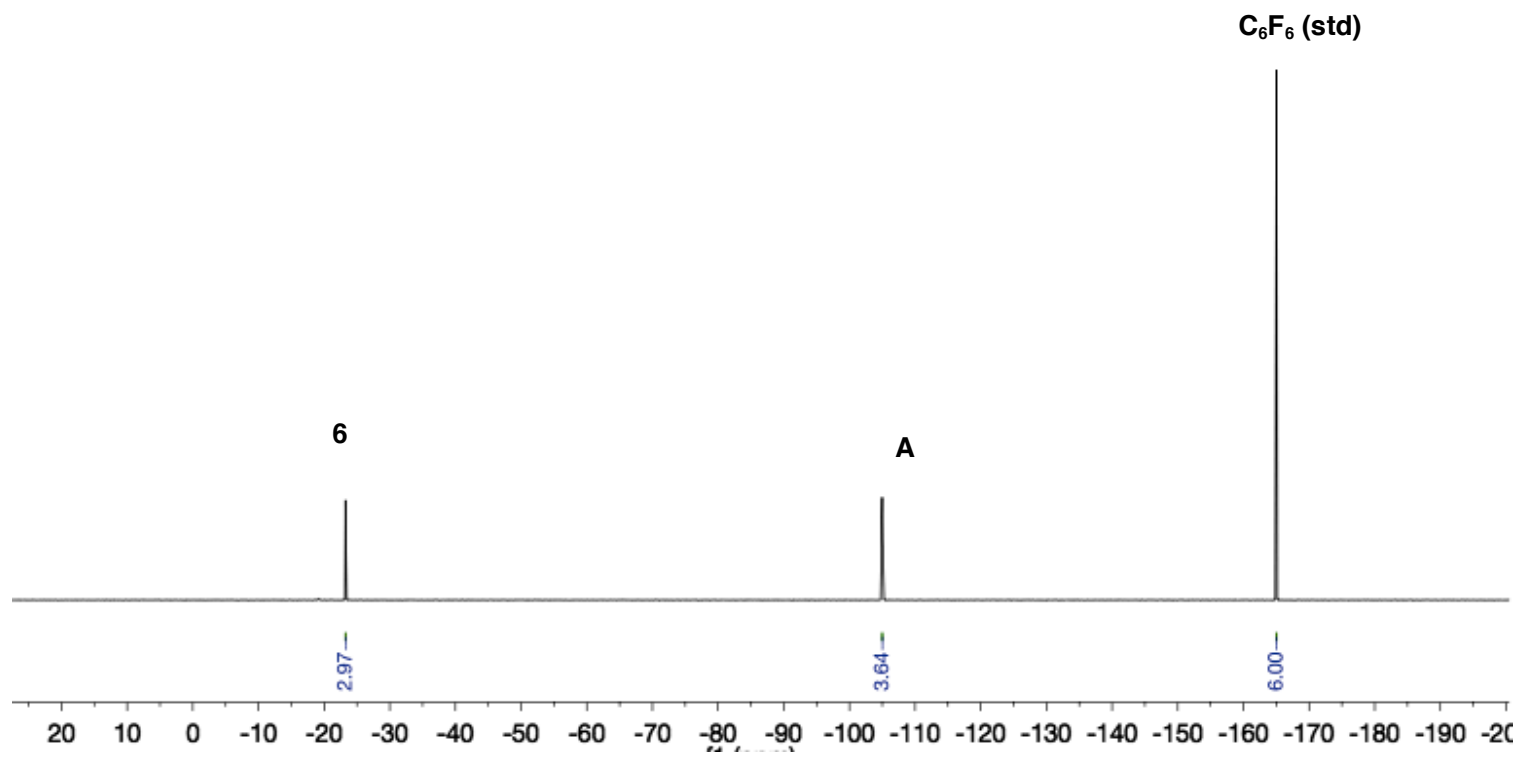

(b)

1

$\mathrm{C}_{6} \mathrm{~F}_{6}$ (std)

A

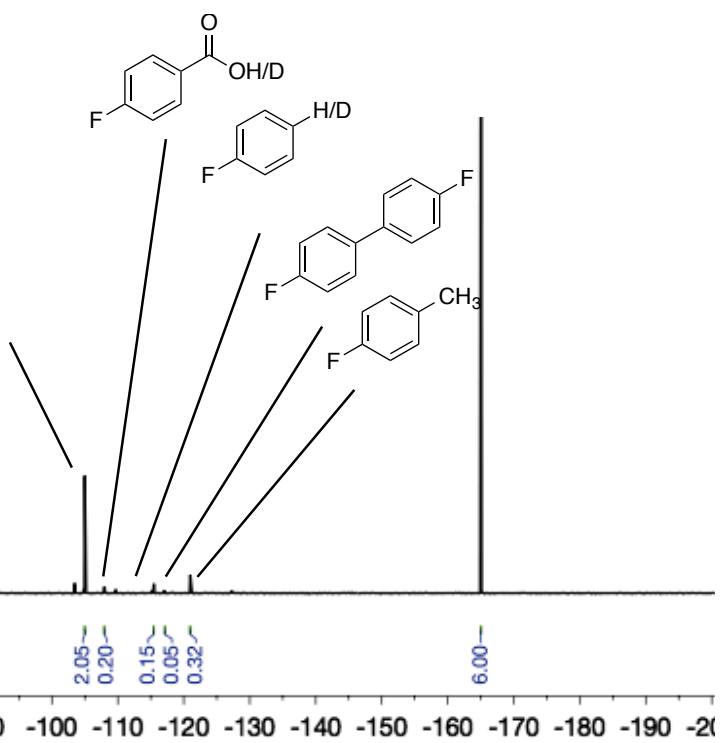

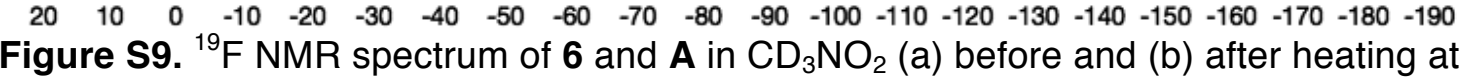
$90{ }^{\circ} \mathrm{C}$ for $60 \mathrm{~min}$. 


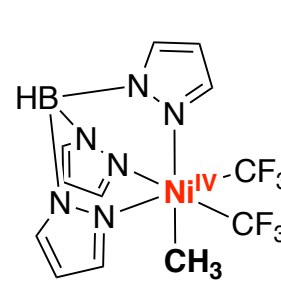

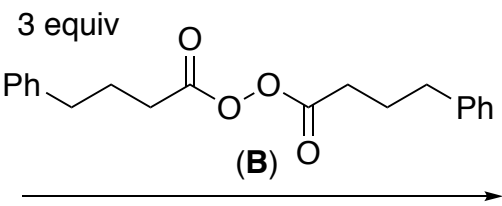

$\mathrm{CD}_{3} \mathrm{NO}_{2}, 80^{\circ} \mathrm{C}, 1 \mathrm{~h}$

(6)

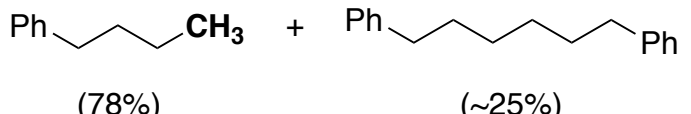

$(78 \%)$

Alkyl C-C coupling with 6: A $4 \mathrm{~mL}$ vial was charged with $\mathrm{TpNi}^{\mathrm{IV}}\left(\mathrm{CF}_{3}\right)_{2}\left(\mathrm{CH}_{3}\right)(6,4.7 \mathrm{mg}$, $0.011 \mathrm{mmol}, 1$ equiv), bis-(4-phenylbutyryl)peroxide (B, $11.2 \mathrm{mg}, 3$ equiv, $0.034 \mathrm{mmol}$ ), and $\mathrm{CD}_{3} \mathrm{NO}_{2}(0.7 \mathrm{~mL})$, and the vial was capped and shaken. The solution was then transferred to a thick-walled J. Young NMR tube. An ${ }^{1} \mathrm{H}$ NMR spectrum was acquired to determine the exact ratio between the $\mathrm{CD}_{3} \mathrm{NO}_{2}$ and 6 . The J. Young NMR tube was then covered in aluminum foil to exclude light and placed in a preheated oil bath at $80^{\circ} \mathrm{C}$ for $60 \mathrm{~min}$. The tube was removed from the oil bath and allowed to cool to room temperature. The crude reaction was then analyzed by ${ }^{1} \mathrm{H}$ NMR spectroscopy. Integration of the $\mathrm{CH}_{3}$ resonance of showed that $n$-butylbenzene was formed in $78 \%$ yield. Diphenylhexane was also detected in the ${ }^{1} \mathrm{H}$ NMR spectrum, but none of the resonances associated with this side product were completely resolved. As such, the yield of 1,6-diphenyl hexane was approximated at $25 \%$ by subtracting the amount of $n$-butylbenzene from the integration of the overlapping $n$-butylbenzene/diphenyl hexane $\mathrm{CH}_{2}$ resonance at $1.33 \mathrm{ppm}$. As is described below, the high ratio of $n$-butylbenzene relative to homocoupled $\mathrm{C}-\mathrm{C}$ products, 1,6-diphenylhexane and ethane (maximum theoretical yield of $11 \%$ ), suggests that neither - $\mathrm{CH}_{3}$ nor $\cdot \mathrm{CH}_{2} \mathrm{CH}_{2} \mathrm{CH}_{2} \mathrm{Ph}$ are present in high concentration throughout the reaction. All listed yields are relative to initial concentration of $\left[\mathrm{Ni}^{\mathrm{IV}}\right]$ complex. Representative NMR spectra are shown in Figures S10 and S11.

The high conversion to and selectivity for $\mathrm{R}-\mathrm{CH}_{3}$ could be rationalized in two ways. One explanation is that the carbon-centered radical, $R \cdot$, is in relatively low concentration throughout the reaction and primarily reacts with 6 through an $S_{H} 2$ mechanism. In this regime the ratio of $\mathrm{R}-\mathrm{CH}_{3}$ to $\mathrm{R}-\mathrm{R}$ is expected to be high. The experimentally observed ratio of $3: 1 \mathrm{R}-\mathrm{CH}_{3}$ to $\mathrm{R}-\mathrm{R}$ is consistent with this regime and is what we propose.

An alternate explanation for the high conversion to and selectivity for $\mathrm{R}-\mathrm{CH}_{3}$ is that an excess of $R \cdot$ is present in solution at any given time, and $R \cdot$ quickly reacts with any $\cdot \mathrm{CH}_{3}$ formed through $\mathrm{Ni}-\mathrm{CH}_{3}$ homolysis. However, in this regime we would also expect a low ratio of $\mathrm{R}-\mathrm{CH}_{3}$ to $\mathrm{R}-\mathrm{R}$. The dimerization of unstabilized and sterically accessible CCRs is thought to be barrierless. ${ }^{9}$ Thus the large quantities of $\mathrm{R} \cdot$ required to efficiently intercept most of the $\cdot \mathrm{CH}_{3}$ formed through $\mathrm{Ni}-\mathrm{CH}_{3}$ homolysis would necessitate the formation an excess of $\mathrm{R}-\mathrm{R}$ (or $\mathrm{H}-\mathrm{R}$ ) relative to $\mathrm{R}-\mathrm{CH}_{3}$. 


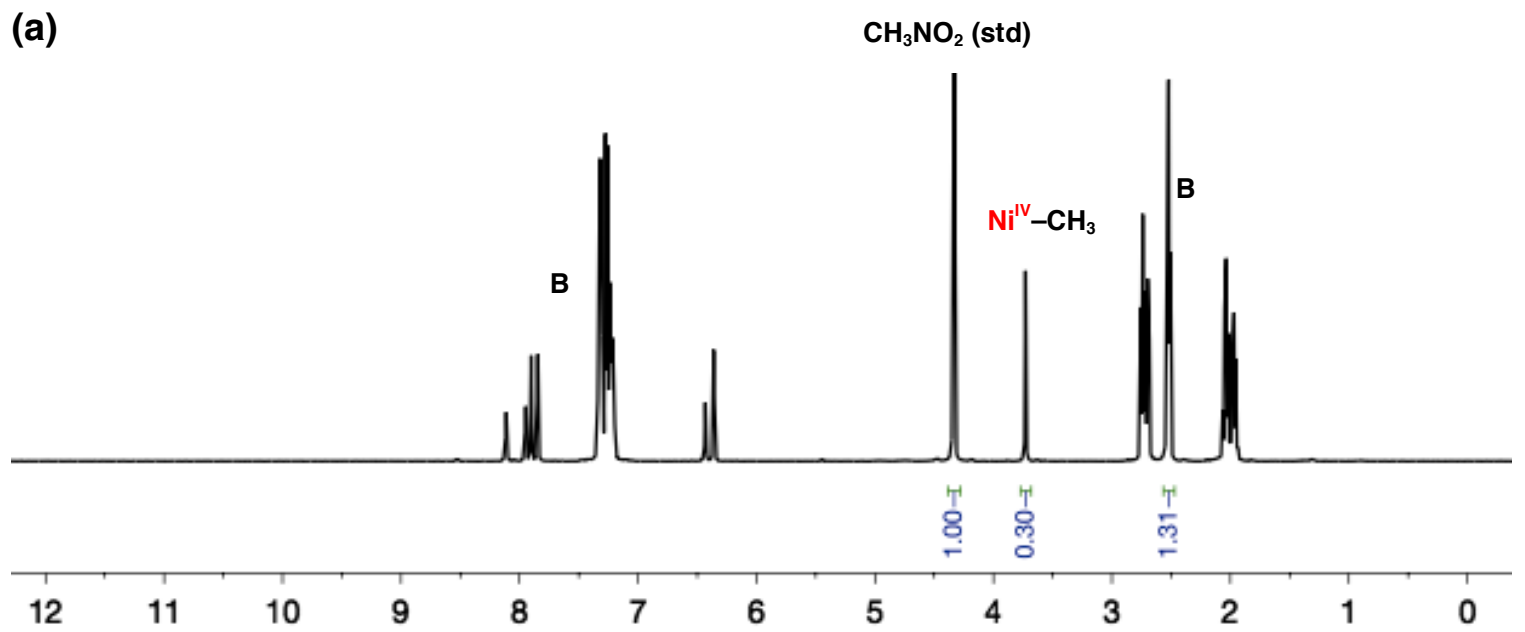

(b)

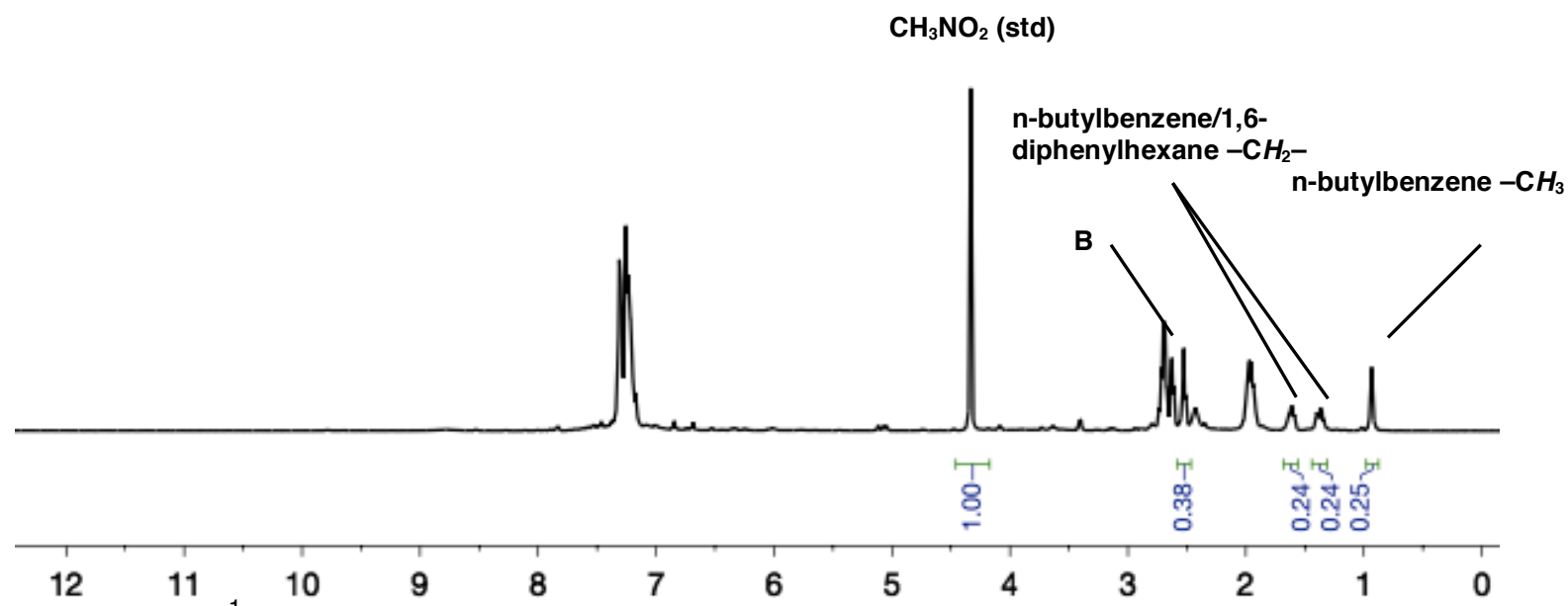

Figure S10. ${ }^{1} \mathrm{H}$ NMR spectrum of $\mathrm{B}$ and $\mathbf{6}$ (a) before and (b) after thermolysis at $80^{\circ} \mathrm{C}$ for $60 \mathrm{~min}$. 
(a)

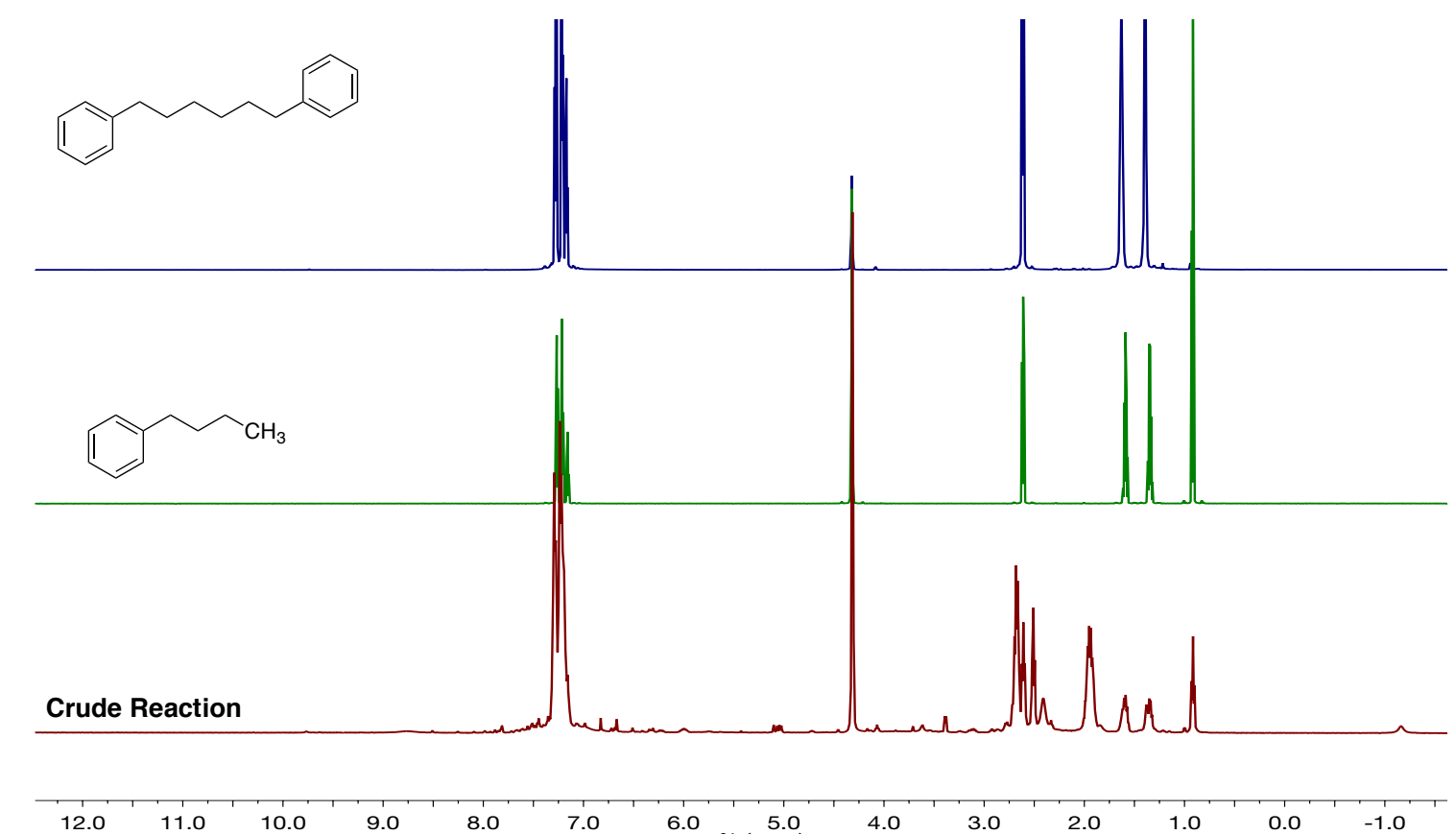

(b)

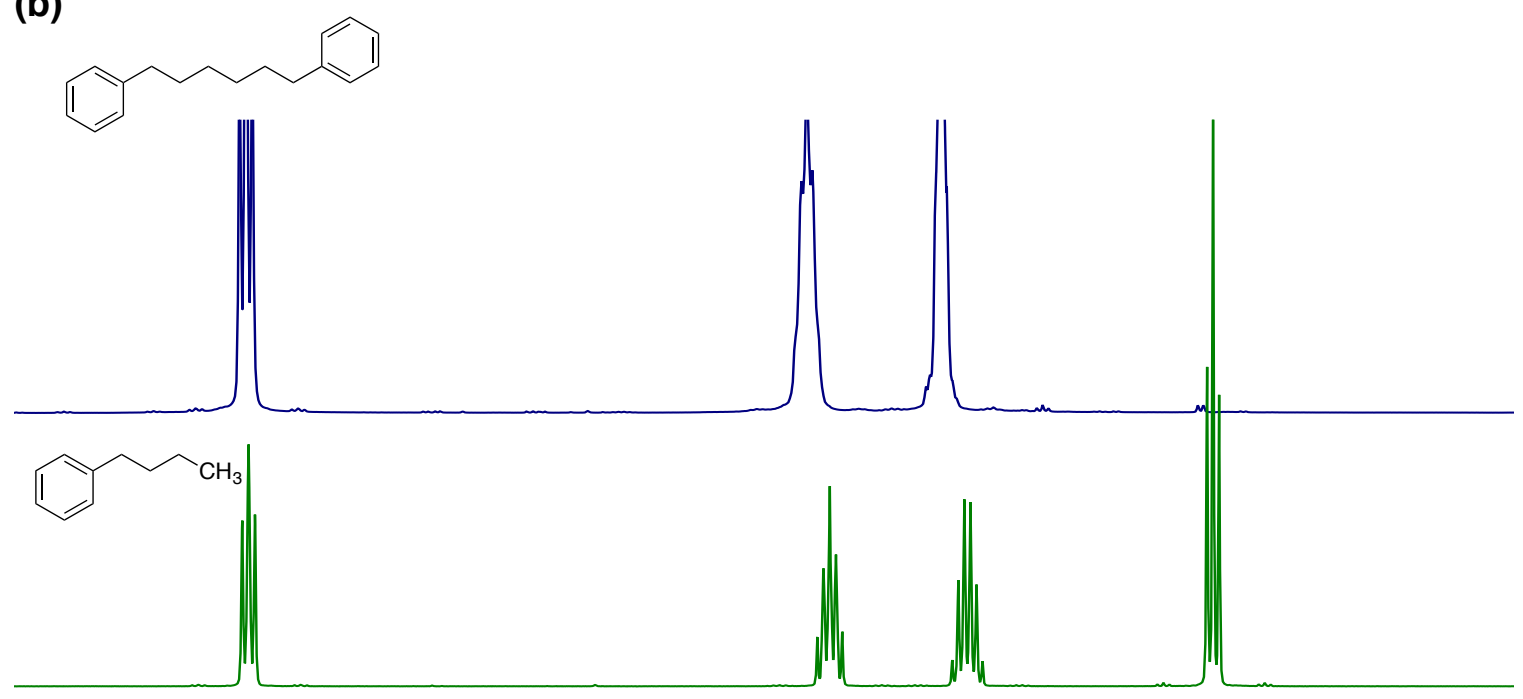

Crude Reaction

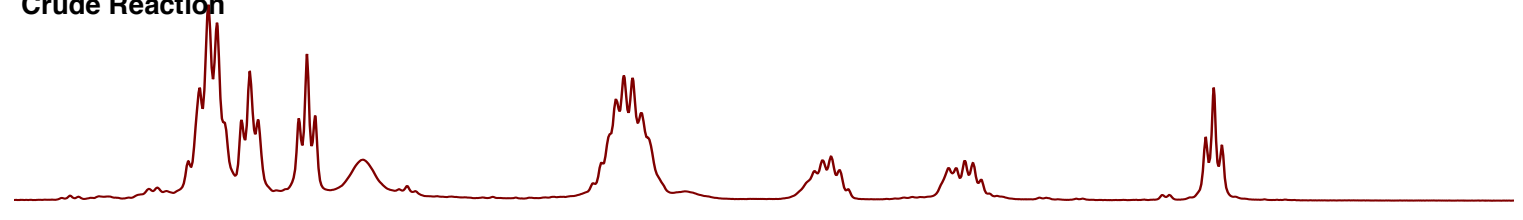

\begin{tabular}{lllllllllllllllllllllllllllllllll}
\hline & 1.0 & 2 & 2.9 & 2.8 & 2.7 & 2.6 & 2.5 & 2.4 & 2.3 & 2.2 & 2.1 & 2.0 & 1.9 & 1.8 & 1.7 & 1.6 & 1.5 & 1.4 & 1.3 & 1.2 & 1.1 & 1.0 & 0.9 & 0.8 & 0.7 & 0.6 & 0.5 & 0.
\end{tabular}

Figure S11. (a) ${ }^{1} \mathrm{H}$ NMR spectra of 1,6-diphenyl hexane (top/blue), n-butylbenzene (middle/green), the crude reaction mixture of $\mathbf{B}$ and $\mathbf{6}$ (bottom/maroon). (b) Aliphatic region 
of the ${ }^{1} \mathrm{H}$ NMR spectra of 1,6-diphenylhexane (top/blue), n-butylbenzene (middle/green), and the crude reaction mixture of $\mathbf{B}$ and $\mathbf{6}$ (bottom, maroon).

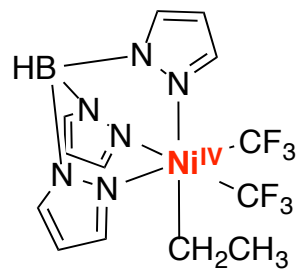

S2<smiles>O=C(OOC(=O)c1ccc(F)cc1)c1ccc(O)cc1</smiles>

(52\% conversion of $\mathbf{A})$<smiles>CCc1ccc(F)cc1</smiles>

$\mathrm{HCF}_{3}$

$(52 \%)$<smiles></smiles>

Reaction of $\mathrm{TpNi}^{\mathrm{IV}}\left(\mathrm{CF}_{3}\right)_{2}\left(\mathrm{CH}_{2} \mathrm{CH}_{3}\right)$ with A. A $4 \mathrm{~mL}$ vial was charged with $\mathrm{TpNi}^{\mathrm{iV}}\left(\mathrm{CF}_{3}\right)_{2}\left(\mathrm{CH}_{2} \mathrm{CH}_{3}\right)(\mathbf{S 2}, 4.8 \mathrm{mg}, 0.011 \mathrm{mmol}, 1$ equiv), bis(4-fluorobenzoyl)peroxide (A, $18 \mathrm{mg}, 0.066 \mathrm{mmol}, 6$ equiv), and $0.7 \mathrm{~mL}$ of $\mathrm{CD}_{3} \mathrm{NO}_{2}$ containing $\mathrm{C}_{6} \mathrm{~F}_{6}(\sim 0.03 \mathrm{M})$ as an internal standard, and the vial was capped and shaken. The solution was then transferred to a thick-walled J. Young tube. A ${ }^{19} \mathrm{~F}$ NMR spectrum was recorded to determine the exact ratio between $\mathrm{TpNi}^{\mathrm{iV}}\left(\mathrm{CF}_{3}\right)_{2}\left(\mathrm{CH}_{2} \mathrm{CH}_{3}\right)$ and internal standard. The J. Young NMR tube was then covered in aluminum foil to exclude light and placed in a preheated oil bath at $90^{\circ} \mathrm{C}$ for $60 \mathrm{~min}$. The tube was removed from the oil bath and allowed to cool to room temperature. The crude reaction was analyzed by ${ }^{1} \mathrm{H}$ and ${ }^{19} \mathrm{~F}$ NMR spectroscopy to determine the yields of the organic products. The identities of 4-fluoroethylbenzene, fluoroform, fluorobenzene, 4,4'-difluorobiphenyl, and 4-fluorobenzoic acid were confirmed by comparison to authentic samples. The presence of ethylene was confirmed by comparison to the ${ }^{1} \mathrm{H}$ NMR spectrum of ethylene in $\mathrm{CD}_{3} \mathrm{NO}_{2}$. The formation of $\mathrm{CHF}_{3}$ and $\mathrm{C}_{2} \mathrm{H}_{4}$ are consistent with decomposition via an apparent $\beta$-hydride elimination to yield $\mathrm{TpNi}^{\mathrm{IV}}\left(\mathrm{CF}_{3}\right)_{2}(\mathrm{H})$ which then decomposes to yield $\mathrm{CHF}_{3}$. This mode of decomposition was independently confirmed to be unrelated to A via the thermolysis of $\mathbf{S 2}$ (see below). All listed yields are relative to initial concentration of $\left[\mathrm{Ni}^{\mathrm{lV}}\right]$ complex. Representative NMR spectra are shown in Figure S12.

(a)

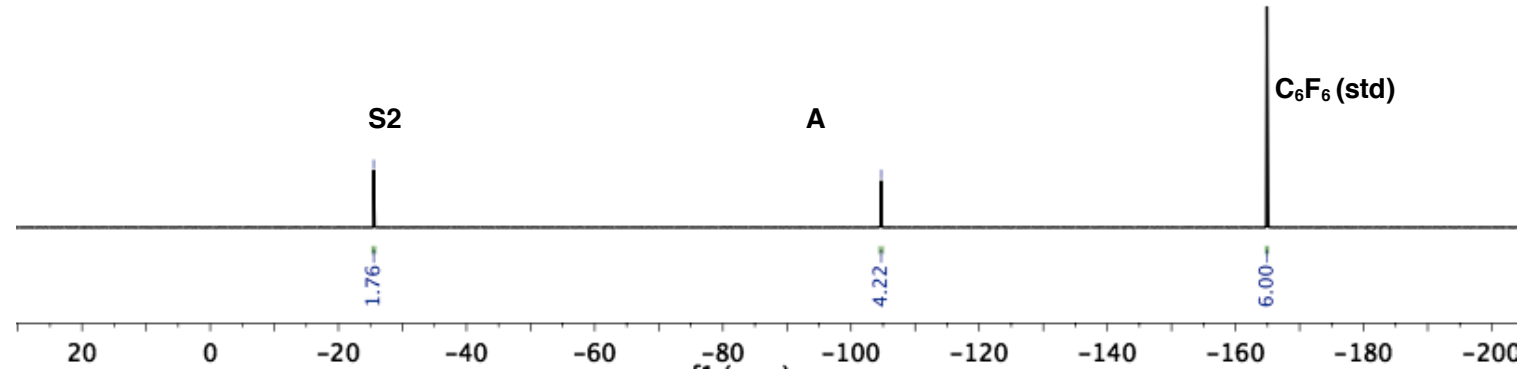




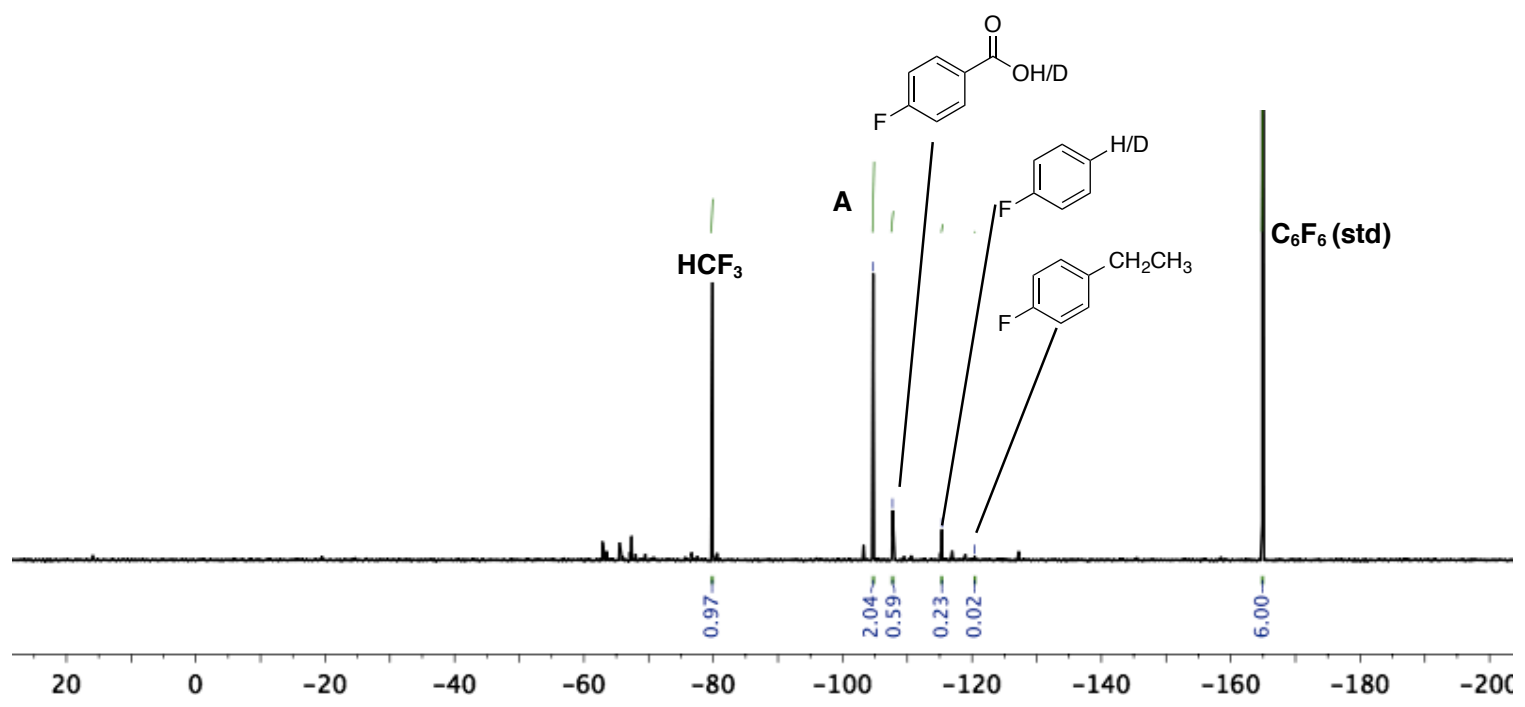

Figure $\mathbf{S 1 2}{ }^{19} \mathrm{~F}$ NMR spectra of the reaction between $\mathbf{S 2}$ with $\mathbf{A}(\mathrm{a})$ before heating and (b) after heating. Intense resonances are truncated for clarity.<smiles></smiles>

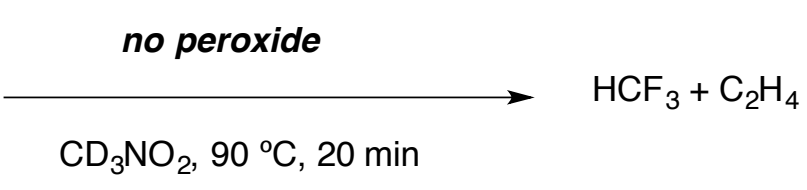

S2

Thermolysis of S2: A $4 \mathrm{~mL}$ vial was charged with $\mathrm{TpNi}^{\mathrm{iV}}\left(\mathrm{CF}_{3}\right)_{2}\left(\mathrm{CH}_{2} \mathrm{CH}_{3}\right)(4.8 \mathrm{mg}, 0.011$ mmol, 1 equiv) and $0.7 \mathrm{~mL}$ of $\mathrm{CD}_{3} \mathrm{NO}_{2}$ containing $\mathrm{C}_{6} \mathrm{~F}_{6}(\sim 0.03 \mathrm{M})$ as an internal standard, and the vial was capped and shaken. The solution was then transferred to a thick-walled J. Young tube. $A{ }^{19} \mathrm{~F}$ NMR spectrum was recorded to determine the exact ratio between $\mathrm{TpNi}^{\mathrm{IV}}\left(\mathrm{CF}_{3}\right)_{2}\left(\mathrm{CH}_{2} \mathrm{CH}_{3}\right)$ and internal standard. The J. Young NMR tube was then covered in aluminum foil to exclude light and placed in a preheated oil bath at $90^{\circ} \mathrm{C}$ for $20 \mathrm{~min}$. The tube was removed from the oil bath and allowed to cool to room temperature. The crude reaction was analyzed by ${ }^{1} \mathrm{H}$ and ${ }^{19} \mathrm{~F}$ NMR spectroscopy. After 10 minutes $\mathbf{S 2}$ was over $95 \%$ consumed and at 20 minutes $\mathbf{S} 2$ was undetectable in the ${ }^{19} \mathrm{~F}$ NMR spectrum. The reaction mixture shows $\mathrm{CHF}_{3}$ and $\mathrm{C}_{2} \mathrm{H}_{4}$ as the primary identifiable organic products. We attribute the formation of these products to an apparent $\beta$-hydride elimination followed by rapid reductive elimination of the putative $\mathrm{Ni}^{\mathrm{IV}}-\mathrm{H}$ to yield $\mathrm{CHF}_{3}$. 
(a)

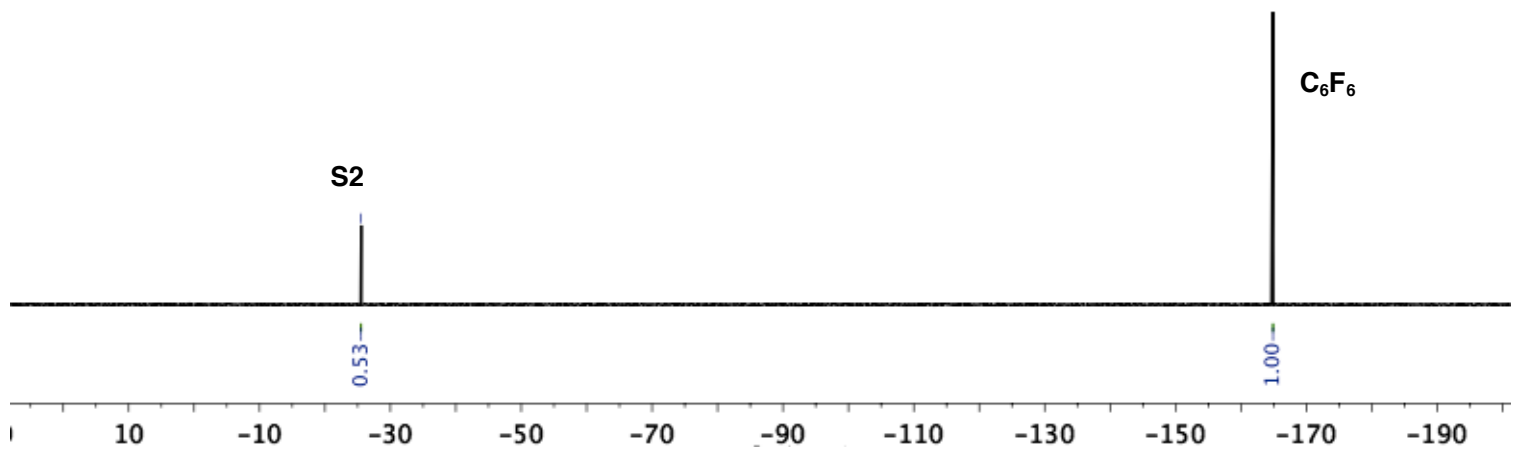

(b)

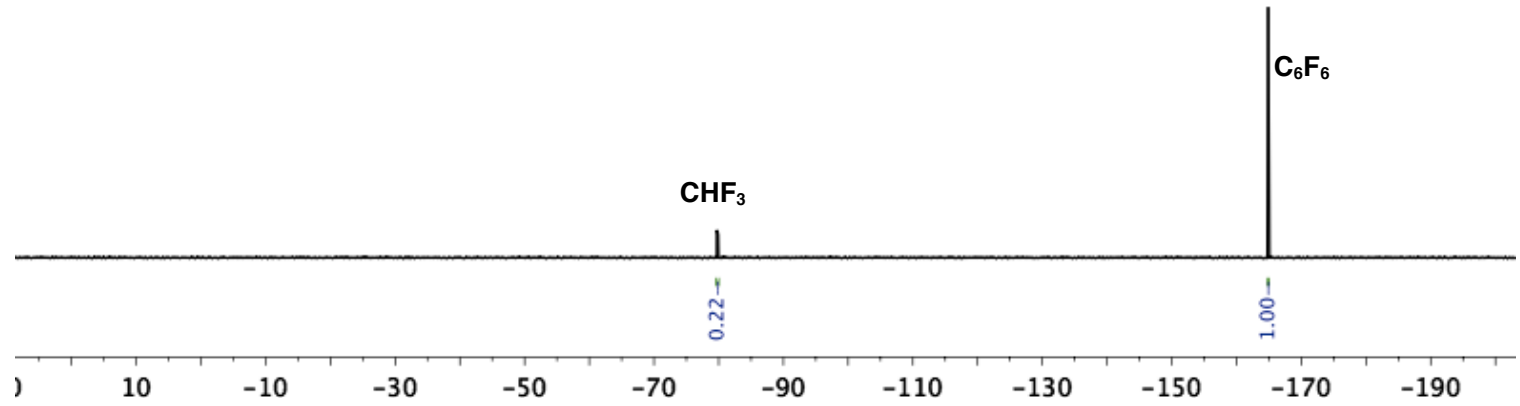

(c)

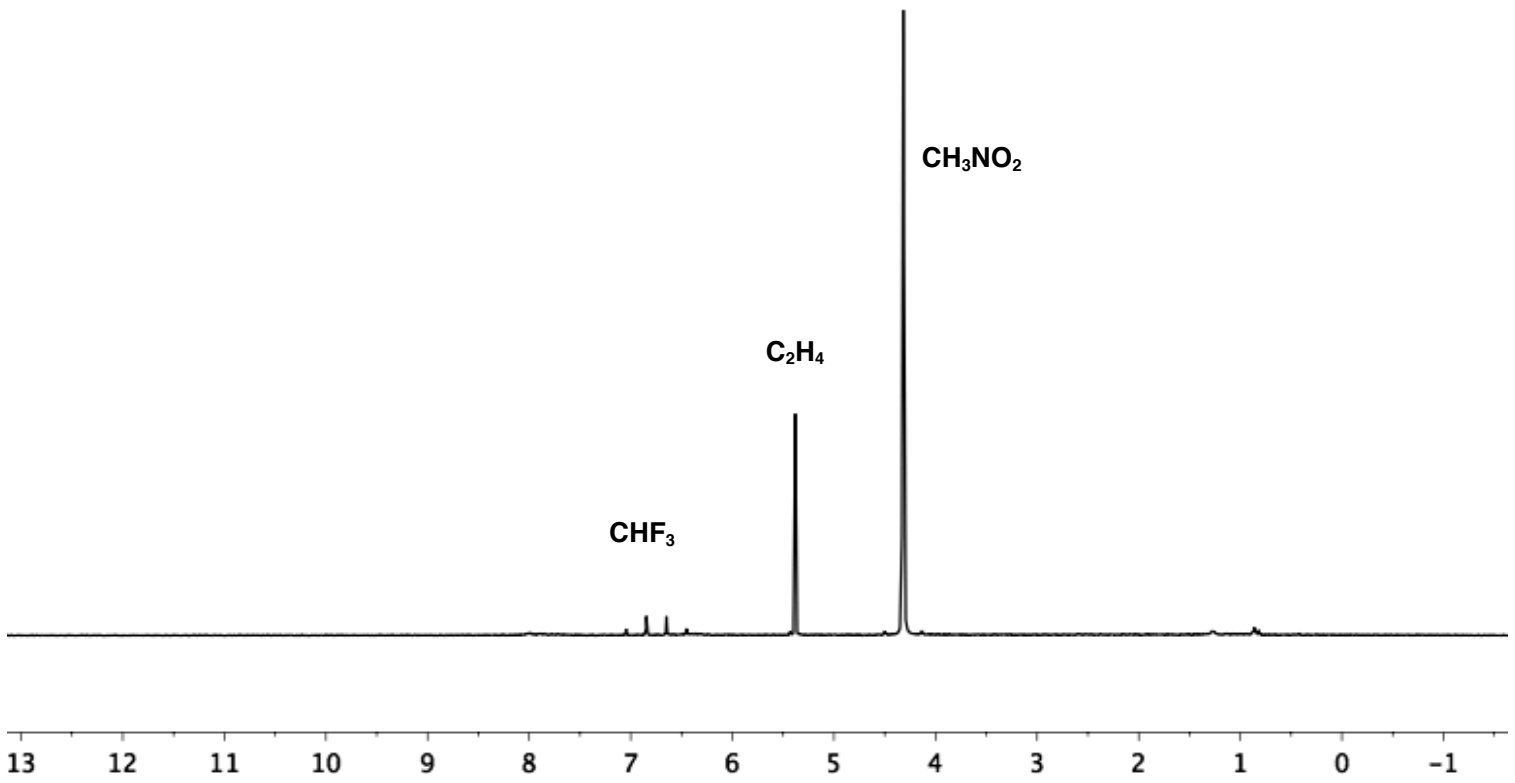



for 20 minutes ( ${ }^{19} \mathrm{~F} \mathrm{NMR}$ ), and (c) after heating for 20 minutes ( ${ }^{1} \mathrm{H}$ NMR). (d) ${ }^{1} \mathrm{H}$ NMR of ethylene in $\mathrm{CD}_{3} \mathrm{NO}_{2}$.

Preparation of the bis-(trifluoroacetyl)peroxide stock solution. A stock solution of bis-trifluoroacetyl peroxide was prepared based on a modified procedure of Hayakawa and coworkers at $1 / 20^{\text {th }}$ the scale. ${ }^{10} \mathrm{~A} 25 \mathrm{~mL}$ round bottom flask was charged with $\mathrm{Na}_{2} \mathrm{O}_{2}\left(0.195 \mathrm{~g}, 2.5 \mathrm{mmol}, 0.5\right.$ equiv), $\mathrm{CH}_{3} \mathrm{CN}(2 \mathrm{~mL})$, and a $1 \mathrm{~cm}$ magnetic stir bar. The flask was sealed with a septum and cooled to $-35^{\circ} \mathrm{C}$ in the glovebox freezer for 30 min. A $4 \mathrm{~mL}$ vial was charged with $\mathrm{CH}_{3} \mathrm{CN}(1 \mathrm{~mL})$ followed by trifluoroacetic anhydride (TFAA, $1.05 \mathrm{~g}, 5 \mathrm{mmol}, 1$ equiv). This solution was cooled at $-35^{\circ} \mathrm{C}$ for $20 \mathrm{~min}$ before it was taken up in a $5 \mathrm{~mL}$ syringe and removed from the glovebox with the syringe needle stuck in a rubber stopper. At this time, the septum-sealed $25 \mathrm{~mL}$ round bottom flask was also removed from the glovebox, placed in a pre-chilled bath of 2-propanol at $-20^{\circ} \mathrm{C}$, and immediately attached to a $\mathrm{N}_{2}$-filled Schlenk line. The suspension was allowed to stir for 5 min at this temperature before the TFAA/ $\mathrm{CH}_{3} \mathrm{CN}$ solution was carefully added dropwise over the course of $30 \mathrm{~min}$. As noted by Hayakawa, an inductive delay may occur with the reaction, so extreme care must be taken to add the TFAA solution slowly. Over the course of the addition, the pale yellow pellets of $\mathrm{Na}_{2} \mathrm{O}_{2}$ were consumed with concomitant formation of a fine white precipitate of sodium trifluoroacetate. After complete addition of the TFAA, the solution was allowed to stir at $-20^{\circ} \mathrm{C}$ for $1 \mathrm{~h}$ before it was allowed to slowly warm to $-5{ }^{\circ} \mathrm{C}$. After $4 \mathrm{~h}$ at $-5^{\circ} \mathrm{C}$, the solution was cooled to $-20^{\circ} \mathrm{C}$, and cold $\left(-20^{\circ} \mathrm{C}\right)$ $\mathrm{CH}_{2} \mathrm{Cl}_{2}(10 \mathrm{~mL})$ was added via syringe, resulting in additional precipitation of sodium trifluoroacetate. The stirring was stopped and the solution was allowed to settle for $1 \mathrm{~h}$. The solution was transferred via cannula into a septum-capped schlenk tube and stored at $-30{ }^{\circ} \mathrm{C}$ until use (within $2 \mathrm{~h}$ ). An aliquot of the solution was analyzed by ${ }^{19} \mathrm{~F}$ NMR spectroscopy to determine the approximate concentration of bis-trifluoroacetyl peroxide $\left(\sim 0.04 \mathrm{M},{ }^{19} \mathrm{~F}\right.$ NMR $\left.\delta,-73.1 \mathrm{ppm}\right)$. The solution also contained unreacted TFAA $\left({ }^{19} \mathrm{~F}\right.$ NMR $\delta,-78.6 \mathrm{ppm})$.

Reaction of 6 with C. A $4 \mathrm{~mL}$ vial was charged with $6(4.6 \mathrm{mg}, 0.011 \mathrm{mmol}, 1$ equiv) and bis-trifluoroacetyl peroxide (C, 2.5 equiv, $0.034 \mathrm{mmol}, 0.7 \mathrm{M}$ in $10: 3 \mathrm{CH}_{3} \mathrm{CN}: \mathrm{CH}_{2} \mathrm{Cl}_{2}$ 
containing $\mathrm{C}_{6} \mathrm{~F}_{6}$ as an internal standard). The vial was capped and shaken. The solution was then transferred to a J. Young NMR tube. A ${ }^{19} \mathrm{~F}$ NMR spectrum was recorded to determine the ratio between the metal complex and internal standard. The J. Young NMR tube was then covered in aluminum foil to exclude light and placed in a preheated oil bath at $45{ }^{\circ} \mathrm{C}$. After $90 \mathrm{~min}, \mathrm{CH}_{3} \mathrm{CF}_{3}$ and $\mathrm{TpNi}^{\mathrm{V}}\left(\mathrm{CF}_{3}\right)_{3}$ were formed in $74 \%$ and $63 \%$ yield, respectively, with full conversion of 6 as determined by ${ }^{19} \mathrm{~F}$ NMR spectroscopy. The formation of these products was found to be dependent on both $\mathbf{3}$ and $\mathbf{C}$. Omission of either of these reactants did not result detectable quantities of $\mathrm{CH}_{3} \mathrm{CF}_{3}$. The identity of $\mathrm{CH}_{3} \mathrm{CF}_{3}$ was assigned based on its ${ }^{19} \mathrm{~F}$ NMR spectrum (experimental, $-61.40, \mathrm{q}, J_{\mathrm{HF}}=13.1$ $\mathrm{Hz}$; literature, = $-61.3 \mathrm{ppm}, \mathrm{q}, J=13 \mathrm{~Hz}$ ). ${ }^{11}$ The nickel-containing product was assigned based on comparison to independently synthesized sample of $\operatorname{TpNi}^{\mathrm{lV}}\left(\mathrm{CF}_{3}\right)_{3}(7)$. Representative NMR spectra are shown in Figure S14. 
(a)

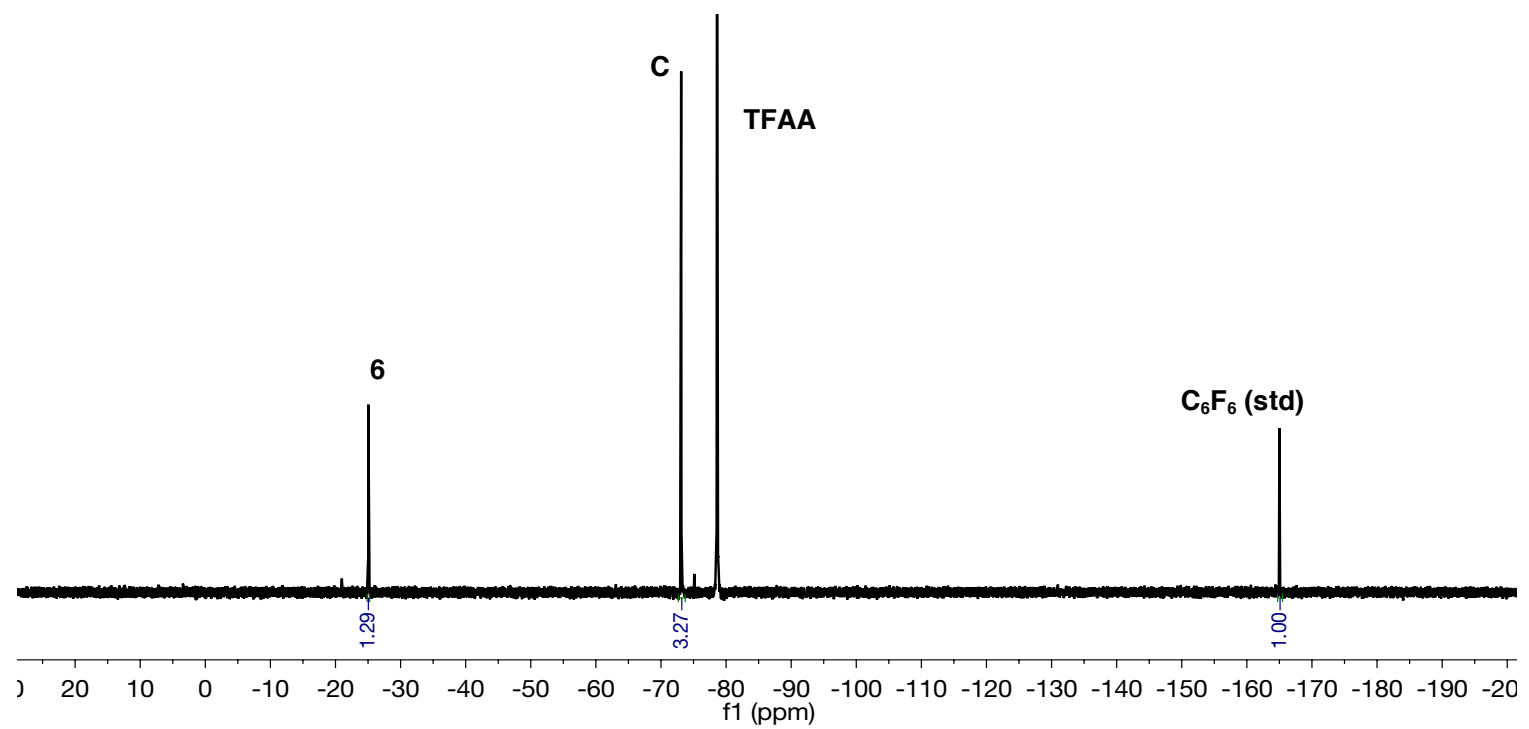

(b)

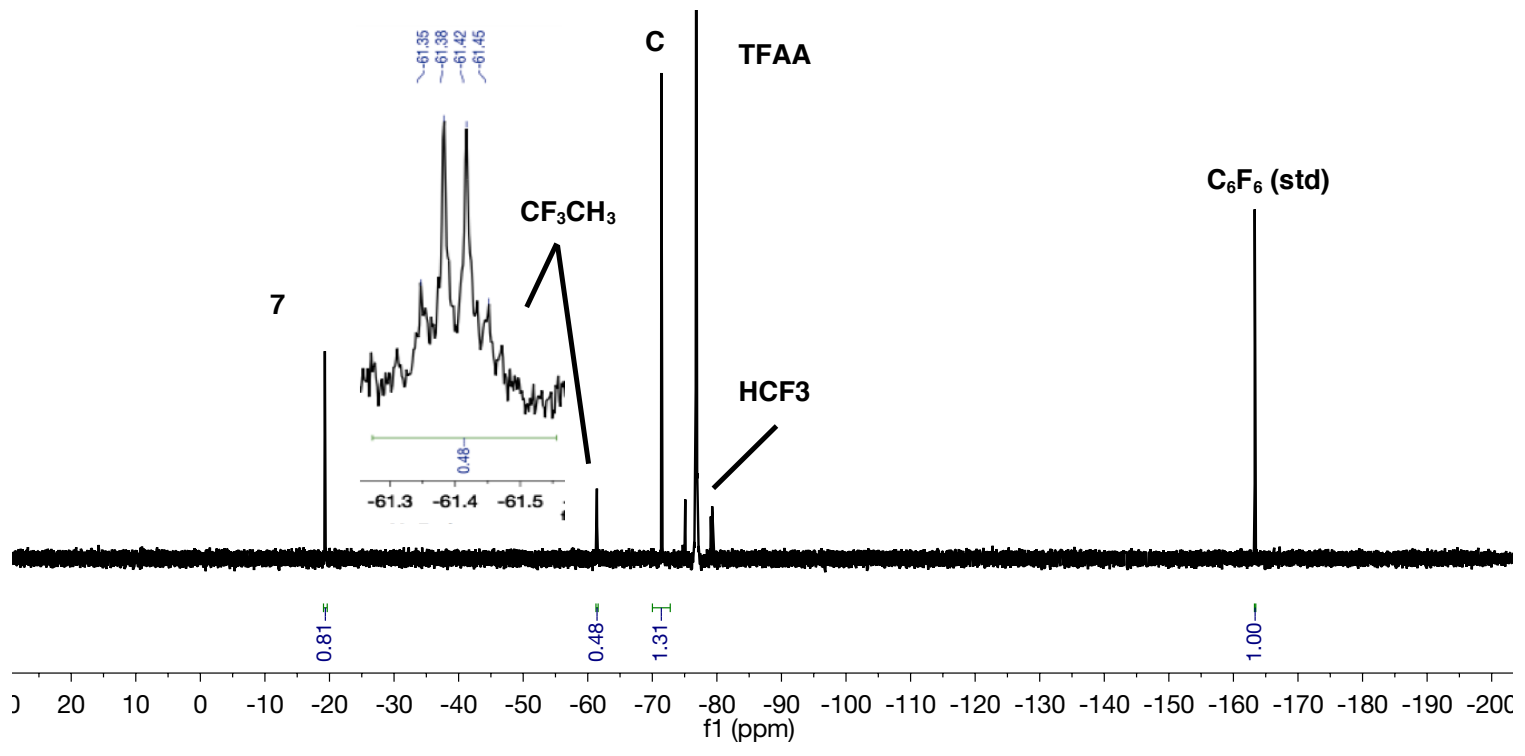

Figure S14. Experimental spectra of $\mathbf{C}$ and $\mathbf{6}$ (a) before heating and (b) after heating at $45^{\circ} \mathrm{C}$ for $90 \mathrm{~min}$. 
Probing for Ni-C homolysis from 6. A $4 \mathrm{~mL}$ vial was charged with $6(4.6 \mathrm{mg}, 0.010 \mathrm{mmol}$, 1 equiv), the appropriate additive, and $\mathrm{CD}_{3} \mathrm{NO}_{2}\left(700 \mu \mathrm{L}\right.$ containing $\mathrm{C}_{6} \mathrm{~F}_{6}$ as an internal standard). The solution was shaken and then transferred to a J. Young NMR tube. The tube was wrapped in aluminum foil to exclude light. Before heating, the solution was analyzed by ${ }^{19} \mathrm{~F}$ NMR spectroscopy to determine the ratio between 6 and the internal standard. The tube was then placed into a preheated NMR spectrometer $\left(90^{\circ} \mathrm{C}\right)$ where the decay of 6 was monitored over the course of $40 \mathrm{~min}$. The rate of decay was minimally affected by the presence of $\beta$-nitrostyrene. See Figure 3 for data. 


\section{EPR and DFT Analysis}

Procedure for the EPR Spectrum of 3. A $4 \mathrm{~mL}$ vial was charged with 3 (1 $\mathrm{mg}, 0.002$ $\mathrm{mmol})$ and anhydrous toluene $(1 \mathrm{~mL})$. This solution $(50 \mu \mathrm{L})$ was transferred to an EPR tube containing anhydrous toluene $(250 \mu \mathrm{L})$. The EPR tube was capped, the solution was mixed by careful shaking, and it was frozen at $100 \mathrm{~K}$ until analysis. EPR spectra were collected at $-176{ }^{\circ} \mathrm{C}$ using a Bruker EMX ESR Spectrometer with a nitrogen-cooled cryostat. The microwave frequency was $9.253 \mathrm{GHz}$, power $=20.046 \mathrm{~mW}$, and modulation amplitude of $1.000 \mathrm{G}$. The EPR spectrum was simulated using the spincount ${ }^{12}$ software package using the following parameters $g_{x}=2.28, g_{y}=2.22, g_{z}=2.01, A_{N}=22 G$ (Figure S13).

Spin densities were calculated using Gaussian $09^{13}$ using the ucam-b3lyp ${ }^{14}$ functional. The Stuttgart/Dresden ECP (SDD) ${ }^{15}$ was used to describe Ni, and the $6-31 \mathrm{G}(\mathrm{d})$ basis set was used for other atoms. Calculated spin density values $>0.02$ are limited to nickel and nitrogens. The higher Mulliken spin density on the nickel atom (1.102) and axial nitrogen atom ( $\left.\mathrm{N}_{\text {axial }} ; 0.094\right)$ relative to equatorial nitrogen atoms $\left(\mathrm{N}_{\mathrm{eq}} ; 0.0082,0.0063\right)$ is qualitatively consistent with the experimentally observed EPR spectrum.

(a.)

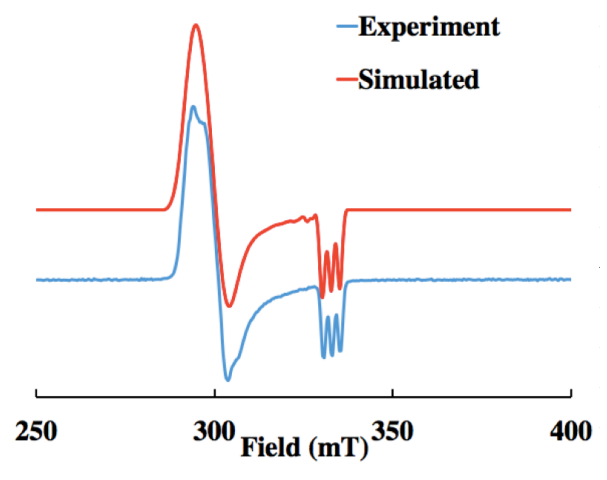

(b.)

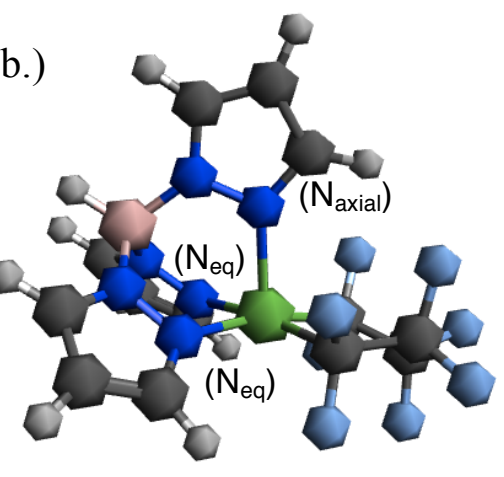

Figure S15. (a) Experimental (blue) and simulated (red) EPR spectrum of 3. (b) DFT optimized ground-state geometry of 3 


\section{Cartesian coordinates for the DFT optimized structure of 3}

$\mathrm{Ni} 0.006750 .06691-0.36489$

F $1.61173-1.65178-1.60782$

F $1.04448-2.359410 .39053$

F $3.77384-1.50262-0.14404$

F $2.68533-0.702831 .57828$

F 3.816891 .372670 .36869

F $3.194440 .63332-1.59958$

F 1.397311 .929991 .05623

F $1.405142 .32622-1.09649$

N $-0.66659-0.093691 .57519$

$\mathrm{N}-2.00737-0.157741 .72792$

$\mathrm{N}-1.31824-1.32180-0.95224$

$\mathrm{N}-2.56985-1.23353-0.45688$

$\mathrm{N}-1.373031 .48790-0.70748$

$\mathrm{N}-2.620481 .23476-0.25001$

C -0.12927 -0.15073 2.79008

H $0.94119-0.113142 .91098$

C - $1.13396-0.255903 .75642$

$\mathrm{H}-1.01659-0.321844 .82636$

C -2.31086 -0.25506 3.03374

H -3.34048 -0.31487 3.35298

C - $1.28462-2.38260-1.75979$

H - $0.36728-2.65392-2.25788$

C -2.53839 -2.99425 -1.79512

$\mathrm{H}-2.83014-3.86957-2.35320$

C -3.32167 -2.22920 -0.94987

$\mathrm{H}-4.35860-2.32334-0.66436$

C -1.41977 $2.66039-1.34318$

$\mathrm{H}-0.528133 .07311-1.78415$

C -2.71425 $3.17883-1.30039$

$\mathrm{H}-3.066354 .10788-1.71948$

C -3.44087 2.23860 -0.59424

$\mathrm{H}-4.482262 .21276-0.31060$

C $1.40125-1.26442-0.30827$

C $2.73397-0.736080 .22436$

C $2.864350 .69014-0.28990$

C $1.476441 .33816-0.15866$

B -2.92568 -0.078220 .49978$

H -4.07965 -0.12807 0.81839 


\section{References}

${ }^{1}$ Bour, J. R.; Camasso, N. M.; Meucci, E. A.; Kampf, J. W.; Canty, A. J.; Sanford, M. S. J. Am. Chem. Soc. 2016, 138, 16105.

${ }^{2}$ (a) Kaplan, P. T.; Xu, L.; Chen, B.; McGarry, K. R.; Yu, S.; Wang, H.; Vicic, D. A. Organometallics 2013, 32, 7552. (b) Yu, S.; Dudkina, Y.; Wang, H.; Kholin, K. V.; Kadirov, M. K.; Budnikova, Y. H.; Vicic, D. A. Dalton Trans. 2015, 44, 19443.

${ }^{3}$ Yu, W.-Y.; Sit, W. N.; Zhou, Z.; Chan, A. S.-C. Org. Lett. $2009,11,3174$.

${ }^{4}$ Babu, K. R.; Zhu, N.; Bao, H. Org. Lett. 2017, 19, 46.

${ }^{5}$ Hansen, M. J.; Lerch, M. M.; Szymanski, W.; Feringa, B. L. Angew. Chem. Int. Ed. 2016, $55,13514$.

${ }^{6}$ (a) Cahiez, G.; Olivier Gager, O.; Buendia, J. Synlett, 2010, 299. (b) Dilauro, G.;

Quivelli, A. F.; Vitale, P.; Capriati, V.; Perna, F. M. Angew. Chem. Int. Ed. 2019, 58, 1799.

${ }^{7}$ Zhang, C.-P.; Wang, H.; Klein, A.; Biewer, C.; Stirnat, K.; Yamaguchi, Y.; Xu, L.; GomezBenitez, V.; Vicic, D. A. J. Am. Chem. Soc. 2013, 135, 8141.

${ }^{8}$ Danen, W. C.; Winter, R. L. J. Am. Chem. Soc. 1971, 93, 716.

${ }^{9}$ Constentin, C.; Savéant, J-M. J. Phys. Chem. A. 2005, 109, 4125.

${ }^{10}$ Hayakawa, Y.; Terasawa, N.; Sawada, H. Polymer 2001, 42, 4081.

${ }^{11}$ Foris, A. Magn. Reson. Chem. 2004, 42, 534.

${ }^{12}$ Provided by Prof. Michael Hendrich, Carnegie Mellon University, Pittsburgh PA, USA

${ }^{13}$ Gaussian 09, revision A.02, Frisch, M. J.; Trucks, G. W.; Schlegel, H. B. Scuseria, G.

E.; Robb, M. A.; Cheeseman, J. R.; Scalmani, G.; Barone, V.; Mennucci, B.; Petersson,

G. A.; Nakatsuji, H.; Caricato, M.; Li, X.; Hratchian, H. P.; Izmaylov, A. F.; Bloino, J.;

Zheng, G.; Sonnenberg, J. L.; Hada, M.; Ehara, M.; Toyota, K.; Fukuda, R.; Hasegawa, J.; Ishida, M.; Nakajima, T.; Honda, Y.; Kitao, O.; Nakai, H.; Vreven, T.; Montgomery, Jr. J. A.; Peralta, J. E.; Ogliaro, F.; Bearpark, M.; Heyd, J. J.; Brothers, E.; Kudin, K. N.;

Staroverov, V. N.; Kobayashi, R.; Normand, J.; Raghavachari, K.; Rendell, A.; Burant, J. C.; lyengar, S. S.; Tomasi, J.; Cossi, M.; Rega, N.; Millam, J. M.; Klene, M.; Knox, J. E.;

Cross, J. B.; Bakken, V.; Adamo, C.; Jaramillo, J.; Gomperts, R.; Stratmann, R. E.;

Yazyev, O.; Austin, A. J.; Cammi, R.; Pomelli, C.; Ochterski, J. W.; Martin, R. L.;

Morokuma, K.; Zakrzewski, V. G.; Voth, G. A.; Salvador, P.; Dannenberg, J. J.;

Dapprich, S.; Daniels, A. D.; Farkas, O.; Foresman, J. B.; Ortiz, J. V.; Cioslowski, J.; and Fox, D. J. Gaussian, Inc., Wallingford CT, 2009.

${ }^{14}$ Lee, C. T.; Yang, W.T. ; Parr, R. G. Phys. Rev. B 1988, 37, 785. (b) Miehlich, B.; Savin, A.; Stoll, H.; Preuss, H. Chem. Phys. Lett. 1989, 157, 200. (c) Becke, A. D. J. Chem. Phys. 1993, 98, 5648.

${ }^{15}$ Andrae, H.; Haussermann, U.; Dolg, M.; Stoll, H.; Preuss, H. Theor. Chim. Acta 1990, $77,123$. 


\section{Spectral Data}

${ }^{11} \mathrm{~B}$ NMR of 3 at $23^{\circ} \mathrm{C}\left(\mathrm{CH}_{3} \mathrm{NO}_{2}\right)$
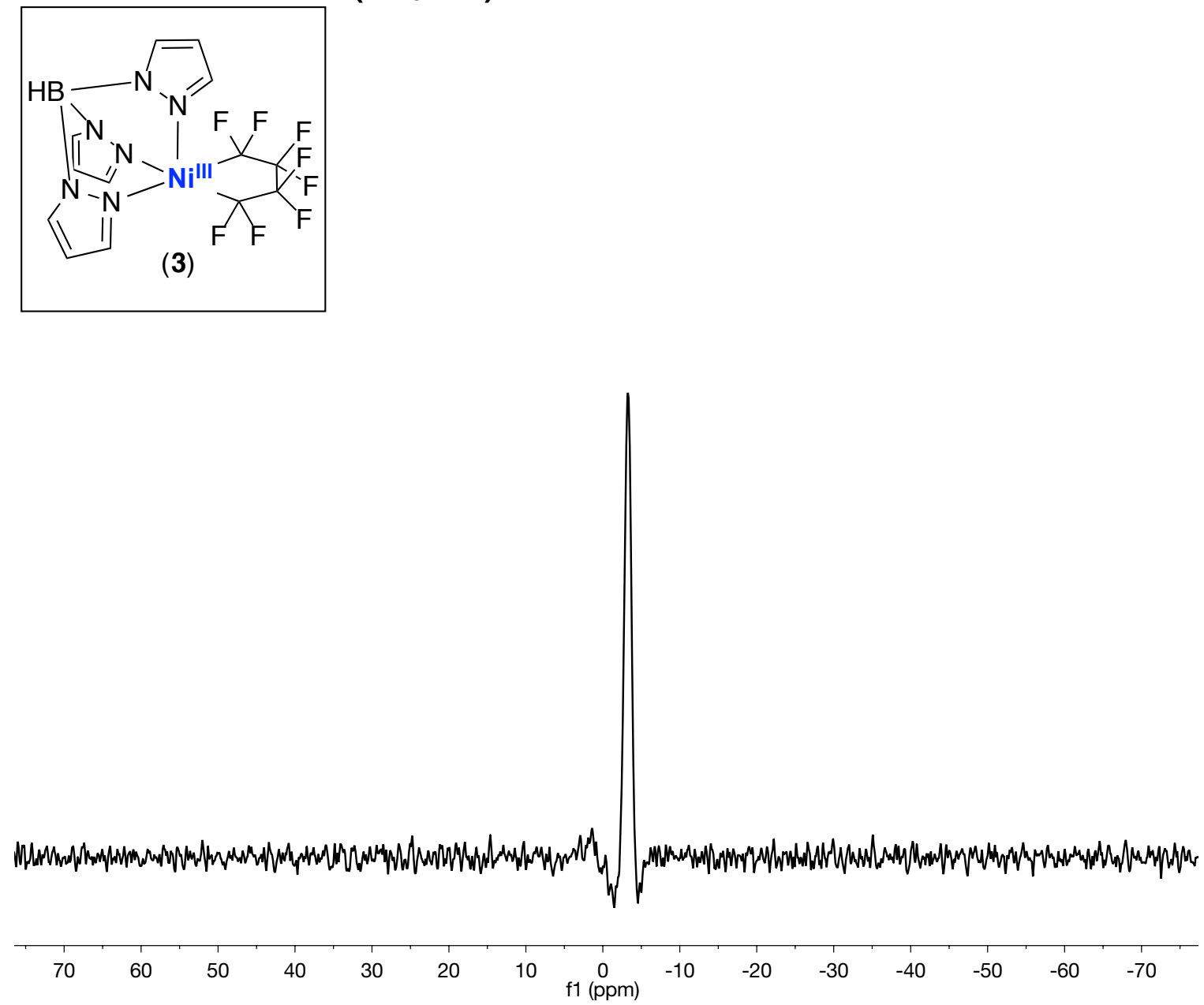
EPR Spectrum of 3 (toluene glass, 100K)
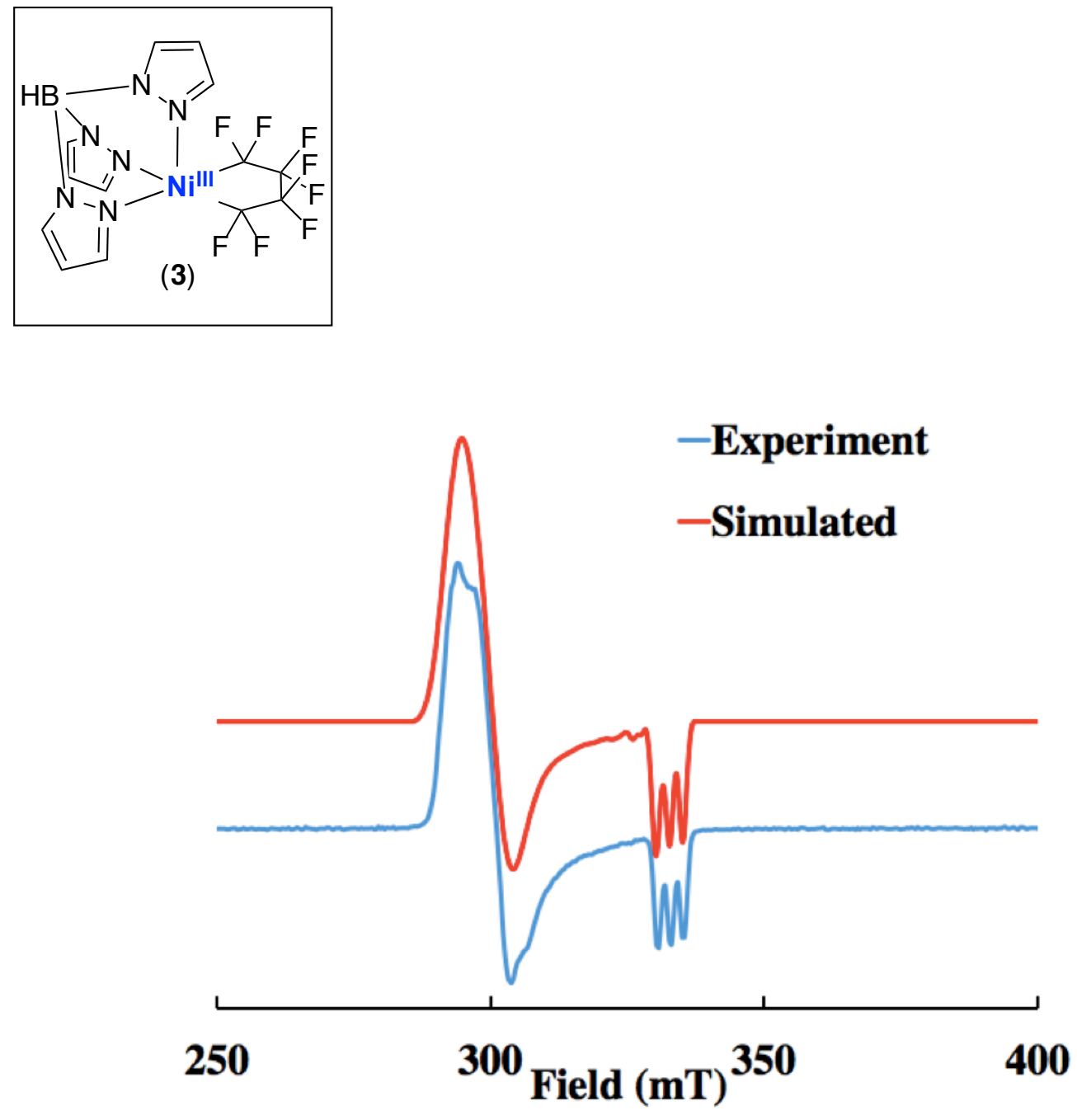


\section{${ }^{1} \mathrm{H}$ NMR of 4 at $23^{\circ} \mathrm{C}\left(\mathrm{CD}_{3} \mathrm{NO}_{2}\right)$}
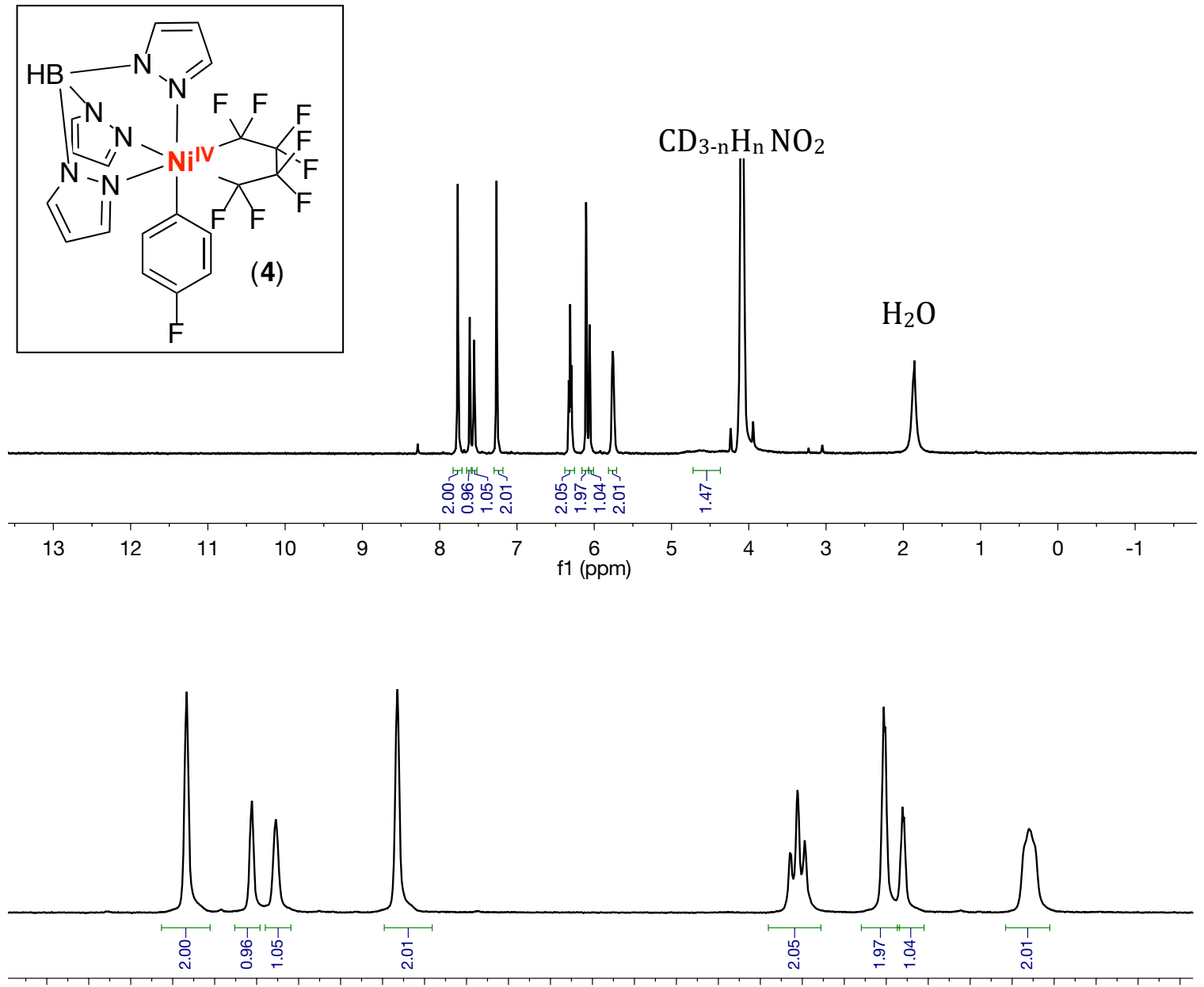

$\begin{array}{lllllllllllllllllllllllllllllllll}8.1 & 8.0 & 7.9 & 7.8 & 7.7 & 7.6 & 7.5 & 7.4 & 7.3 & 7.2 & 7.1 & 7.0 & 6.9 & 6.8 & 6.7 & 6.6 & 6.5 & 6.4 & 6.3 & 6.2 & 6.1 & 6.0 & 5.9 & 5.8 & 5.7 & 5.6 & 5.5 & 5.4\end{array}$ f1 (ppm) 


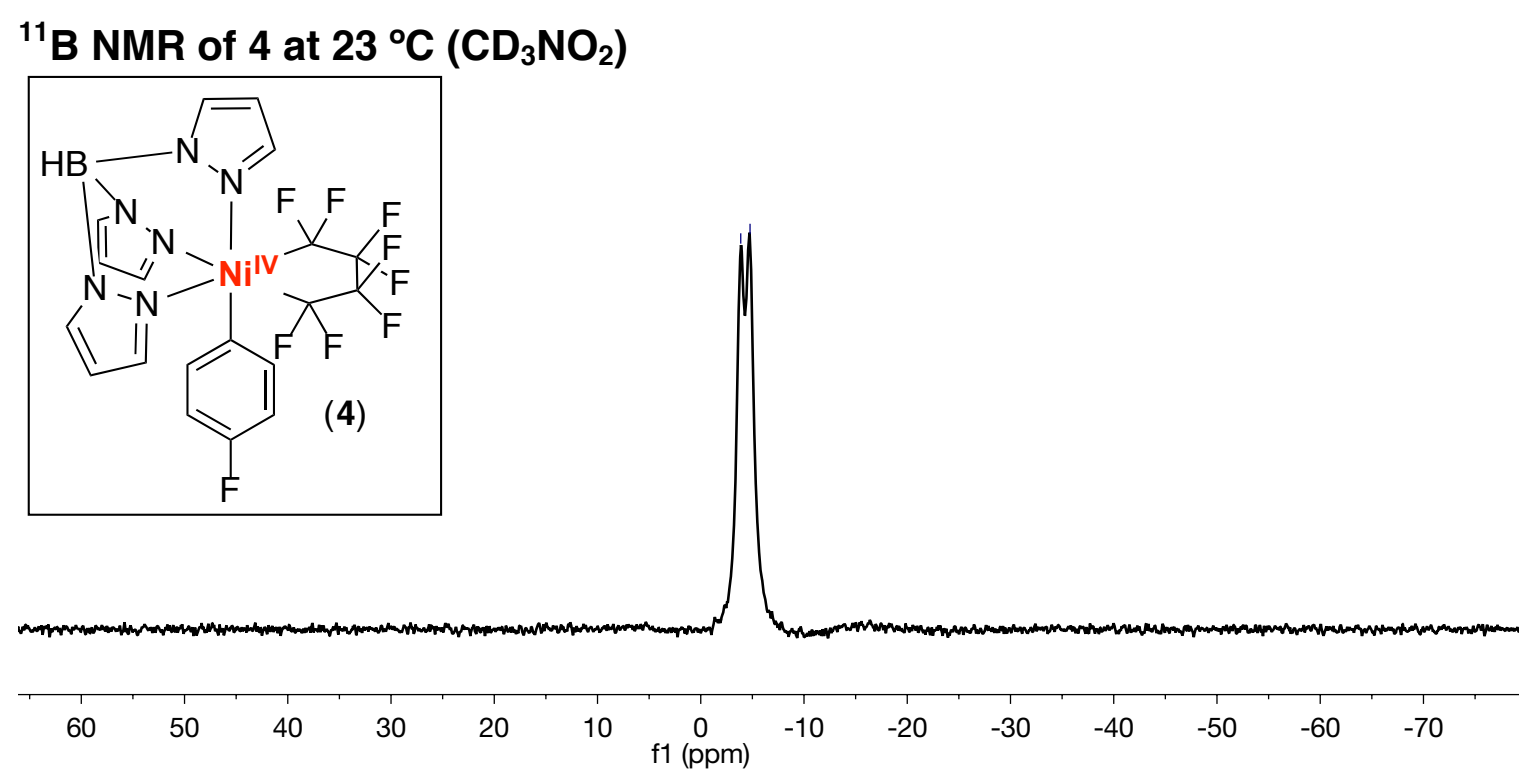




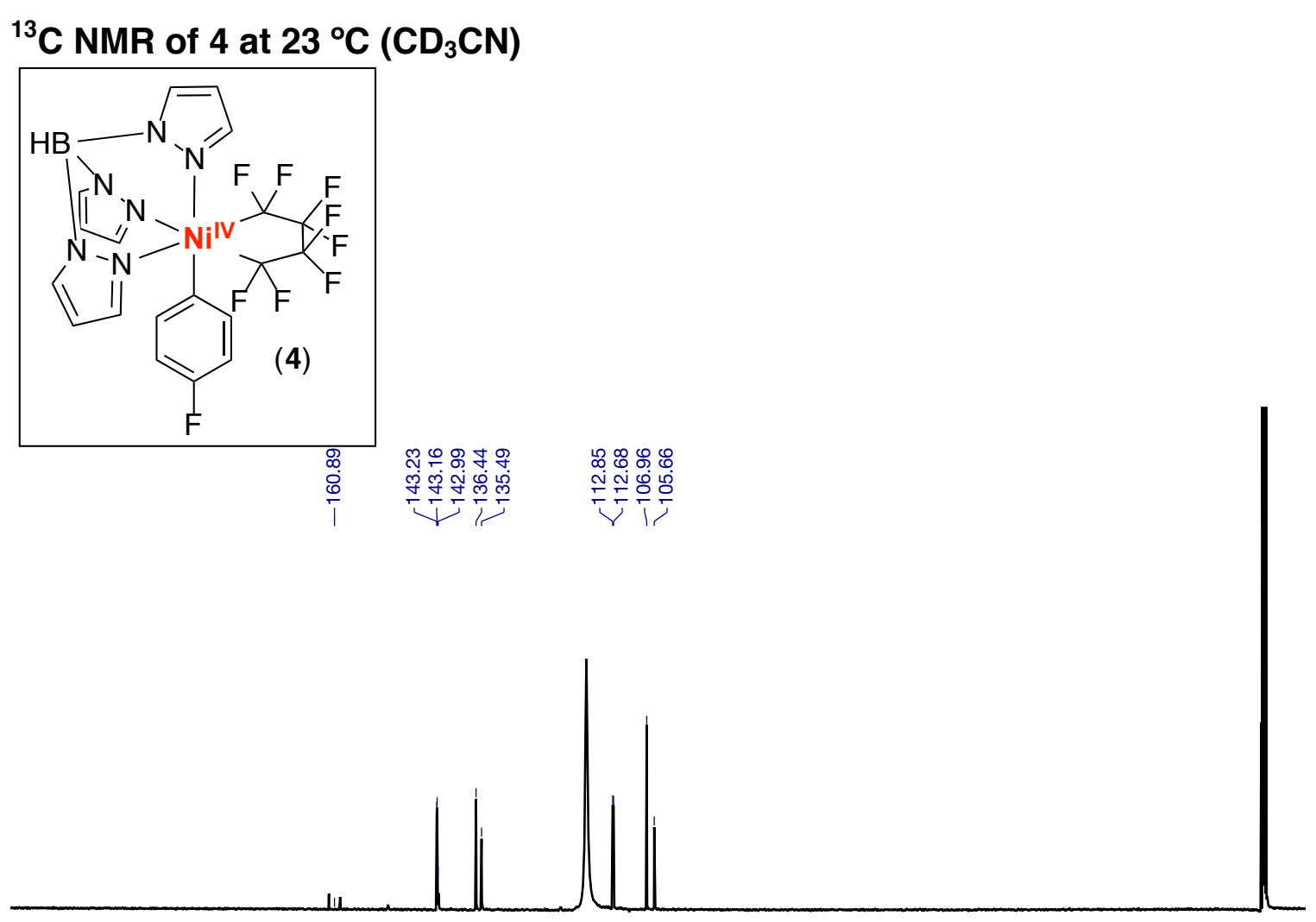

$\begin{array}{llllllllllllllllllll}210 & 200 & 190 & 180 & 170 & 160 & 150 & 140 & 130 & \begin{array}{c}120 \\ \mathrm{f} 1\end{array}(\mathrm{ppm}) \\ (10 & 100 & 90 & 80 & 70 & 60 & 50 & 40 & 30 & 20 & 10 & 0\end{array}$ 

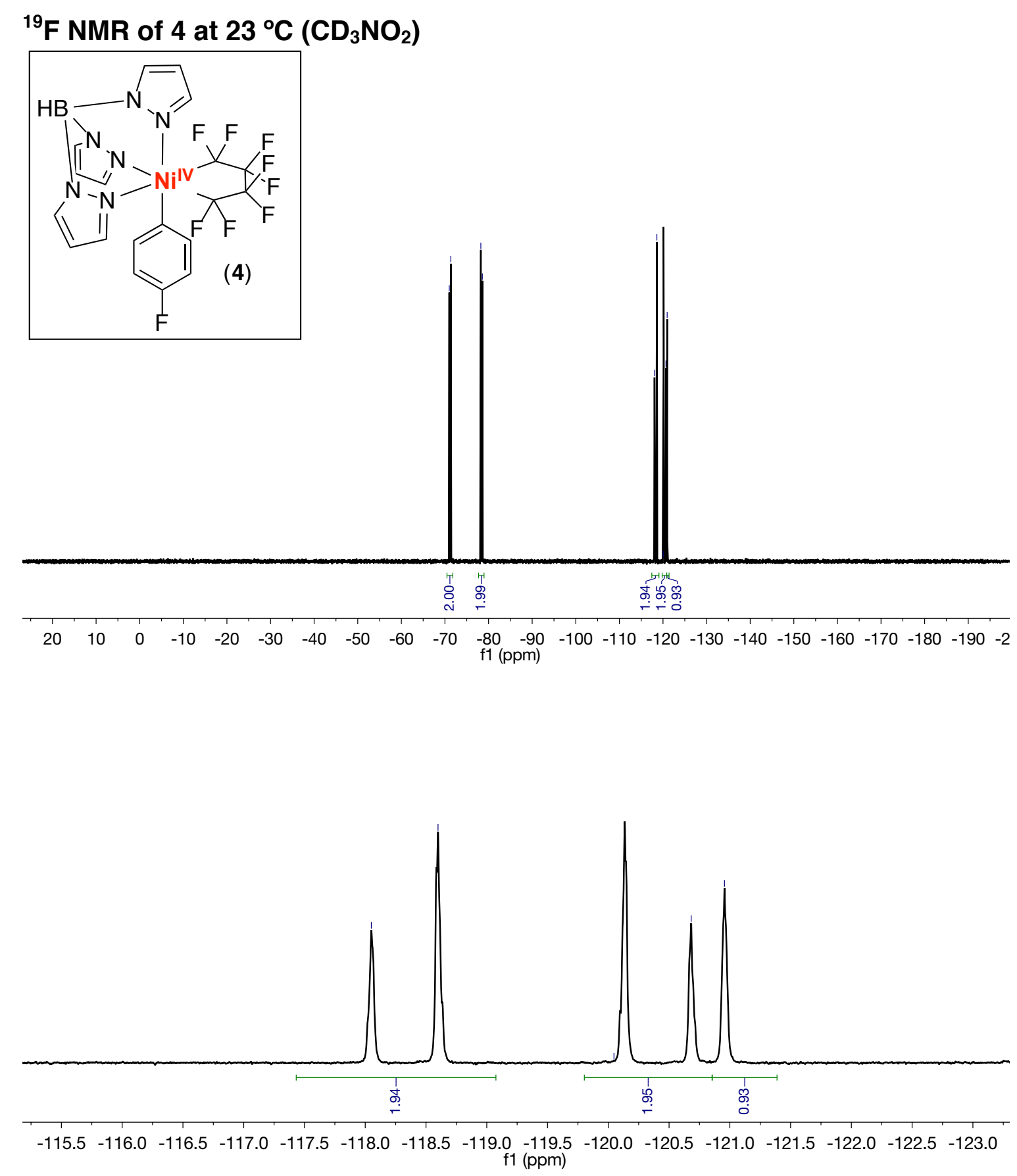


\section{${ }^{1} \mathrm{H}$ NMR of 5 at $-25^{\circ} \mathrm{C}\left(\mathrm{CD}_{3} \mathrm{CN}\right)$}

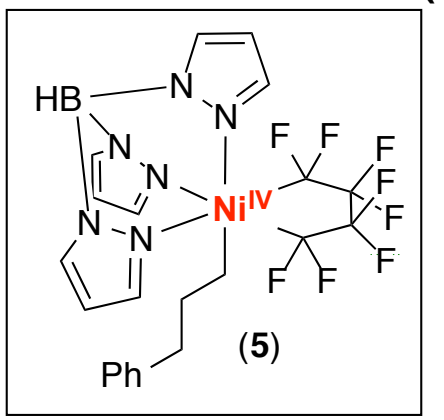

$$
\mathrm{CD}_{3-\mathrm{n}} \mathrm{H}_{\mathrm{n}} \mathrm{CN}
$$

$\mathrm{H}_{2} \mathrm{O}$
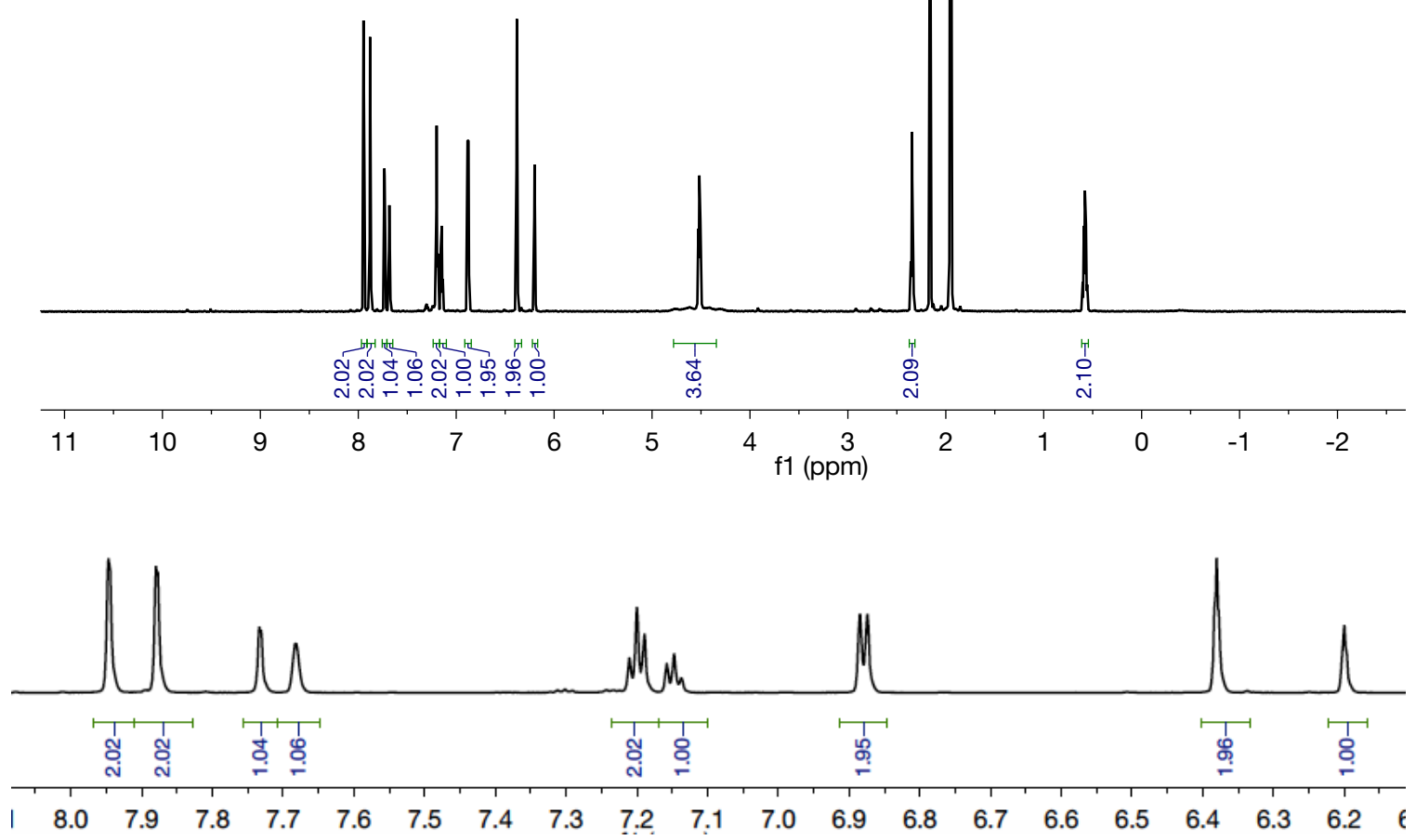
${ }^{11} \mathrm{~B}$ NMR of 5 at $-25^{\circ} \mathrm{C}\left(\mathrm{CD}_{3} \mathrm{CN}\right)$
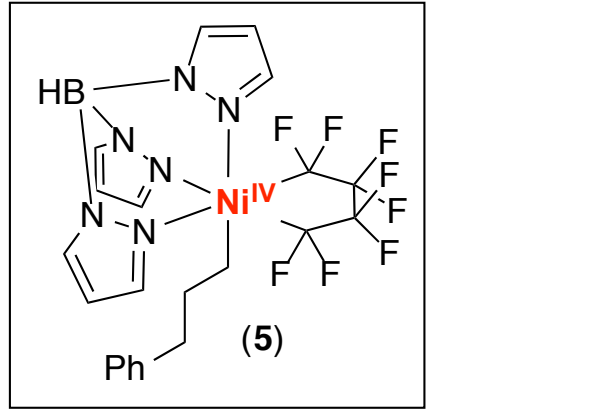

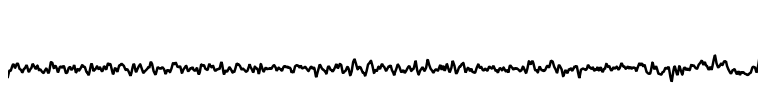

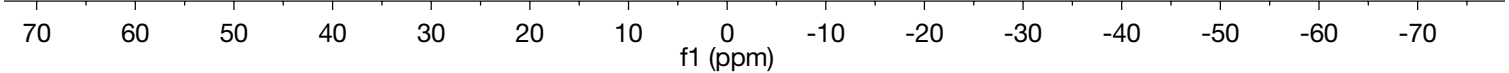


${ }^{13} \mathrm{C}$ NMR of 6 at $-25^{\circ} \mathrm{C}\left(\mathrm{CD}_{3} \mathrm{CN}\right)$

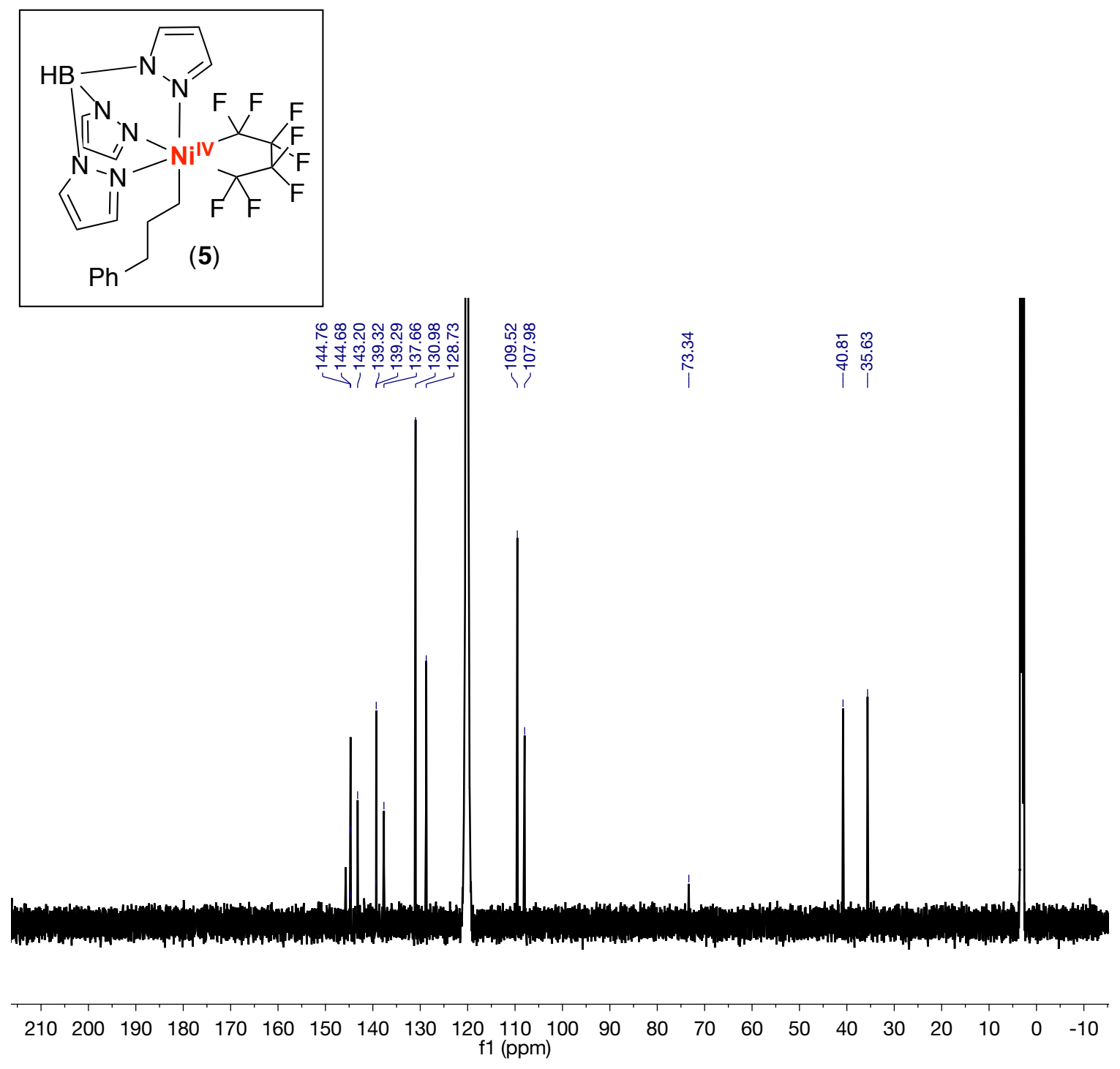




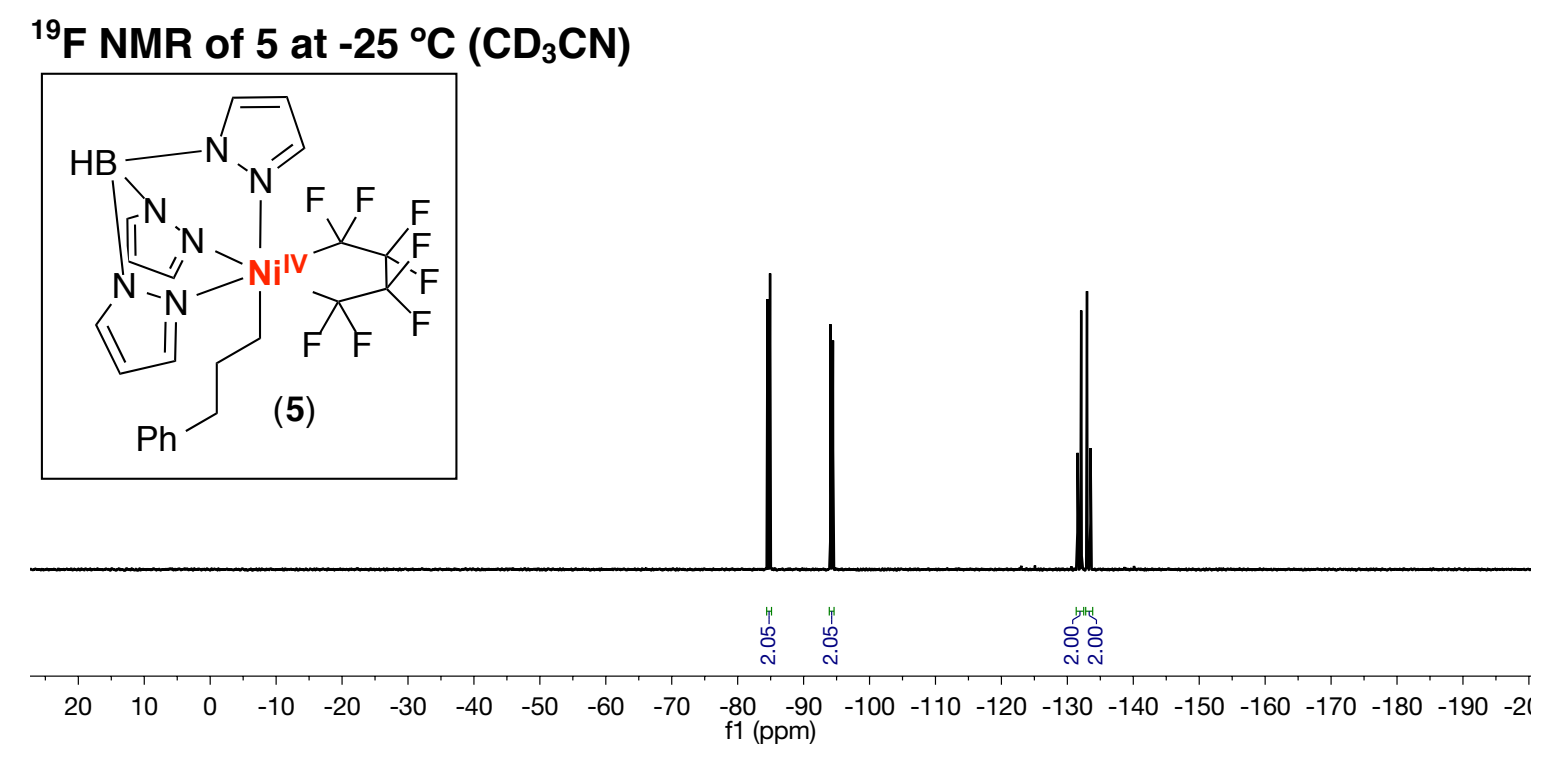


${ }^{1} \mathrm{H}$ NMR of Int-1 at $23^{\circ} \mathrm{C}\left(\mathrm{CD}_{2} \mathrm{Cl}_{2}\right)$
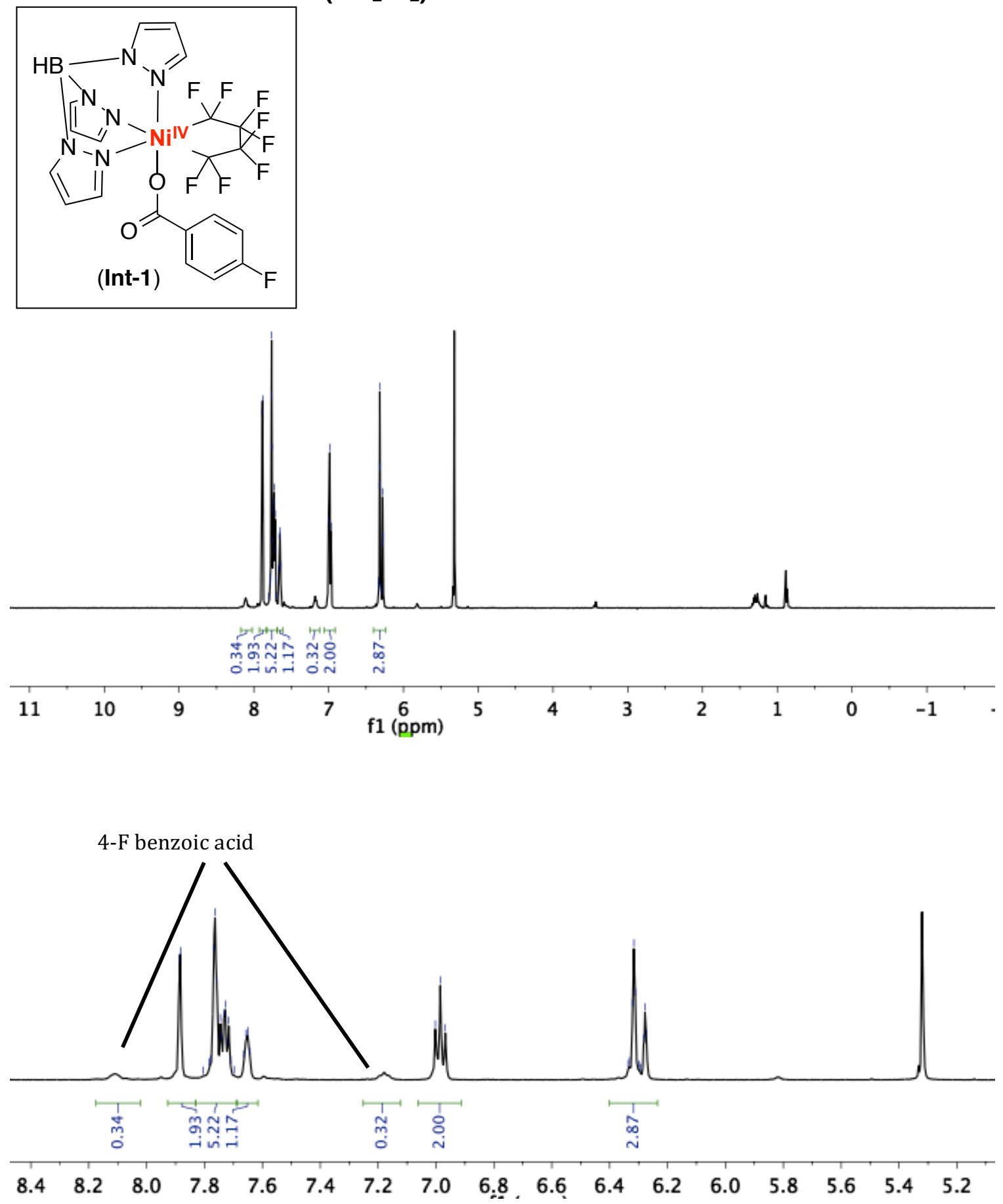
${ }^{11} \mathrm{~B}$ NMR of Int-1 at $23^{\circ} \mathrm{C}\left(\mathrm{CD}_{2} \mathrm{Cl}_{2}\right)$
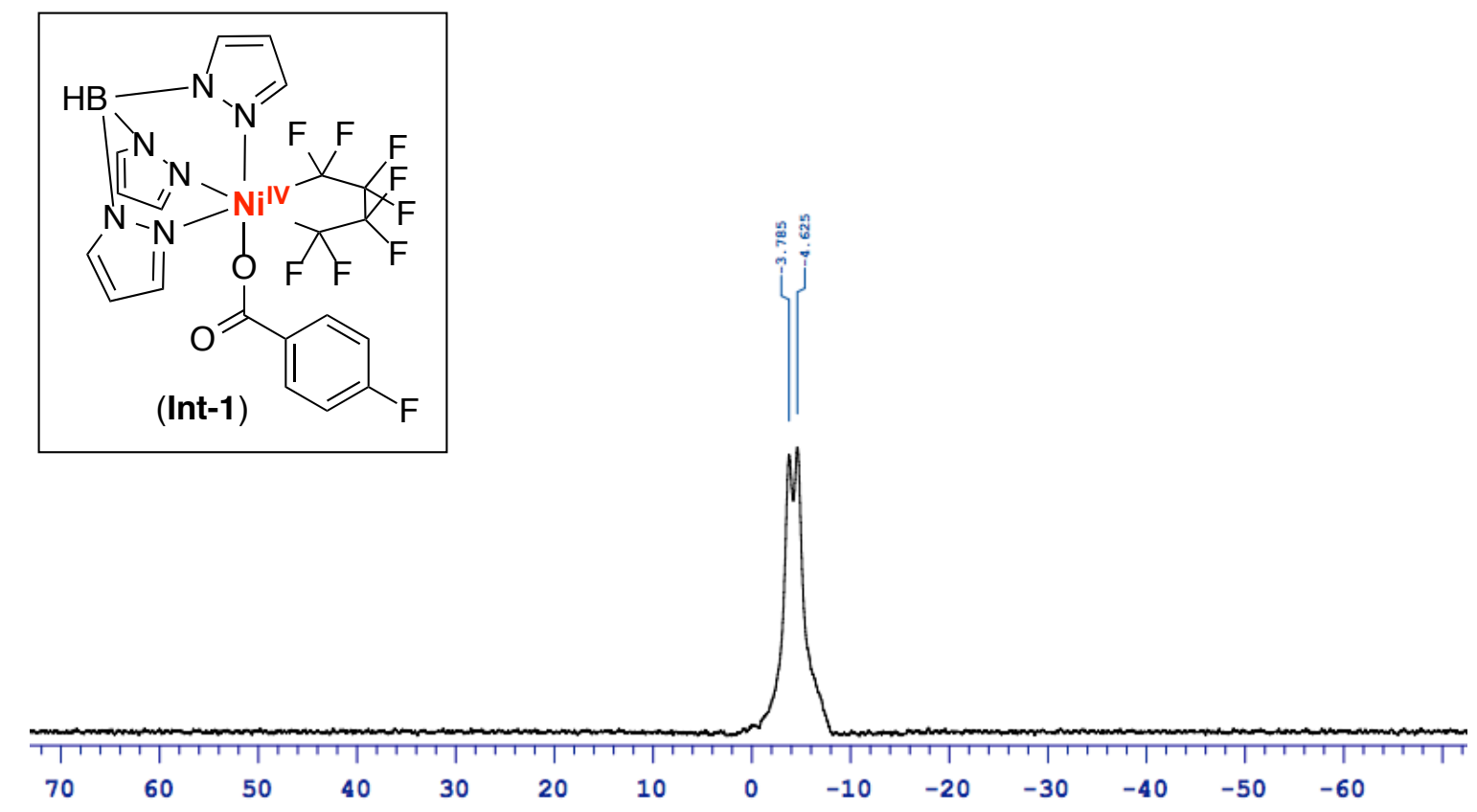

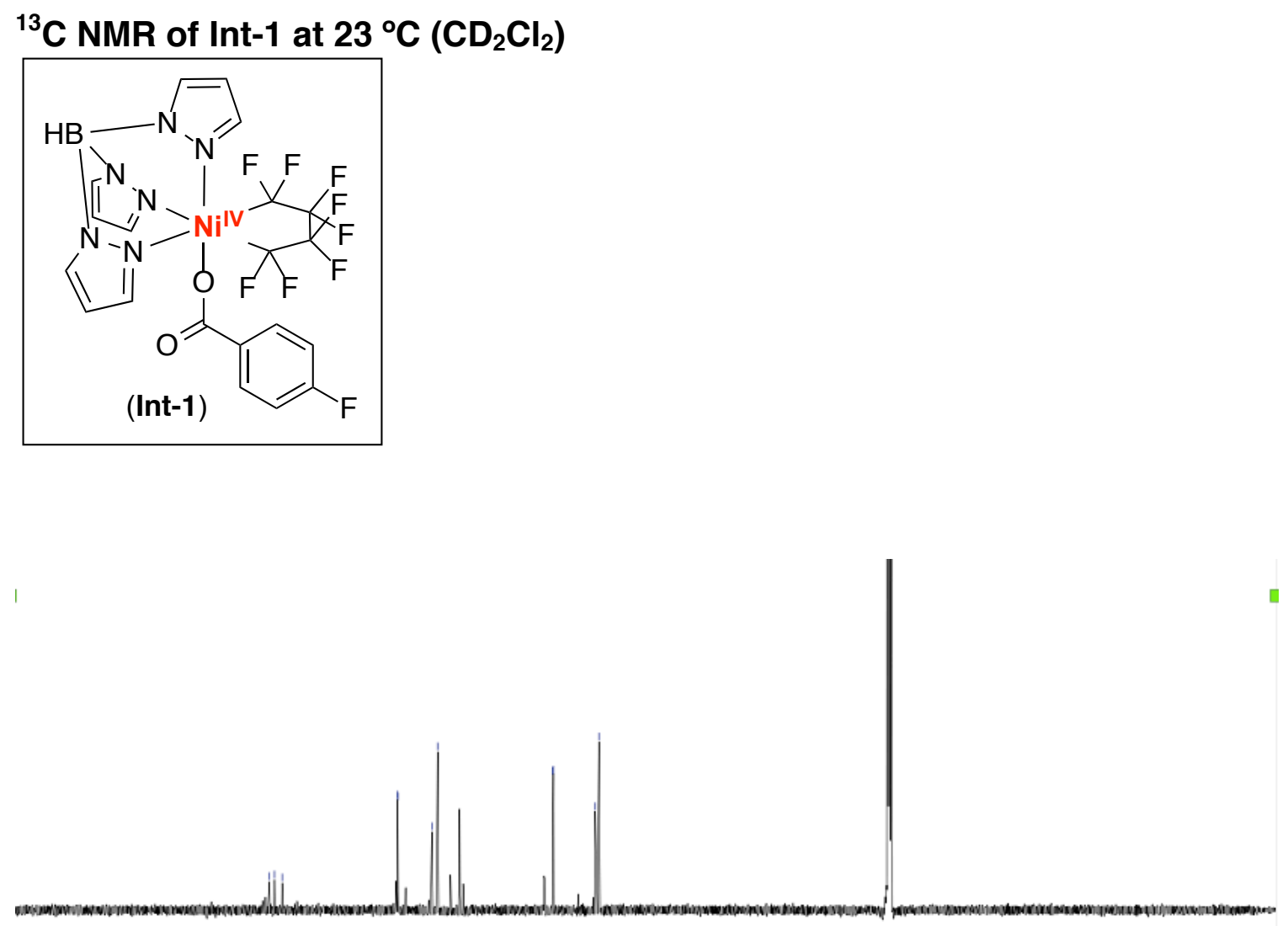

$\begin{array}{lllllllllllllllllllllll}310 & 200 & 190 & 180 & 170 & 160 & 150 & 140 & 130 & 120 & 110 & 100 & 90 & 80 & 70 & 60 & 50 & 40 & 30 & 20 & 10 & 0 & -10\end{array}$ 


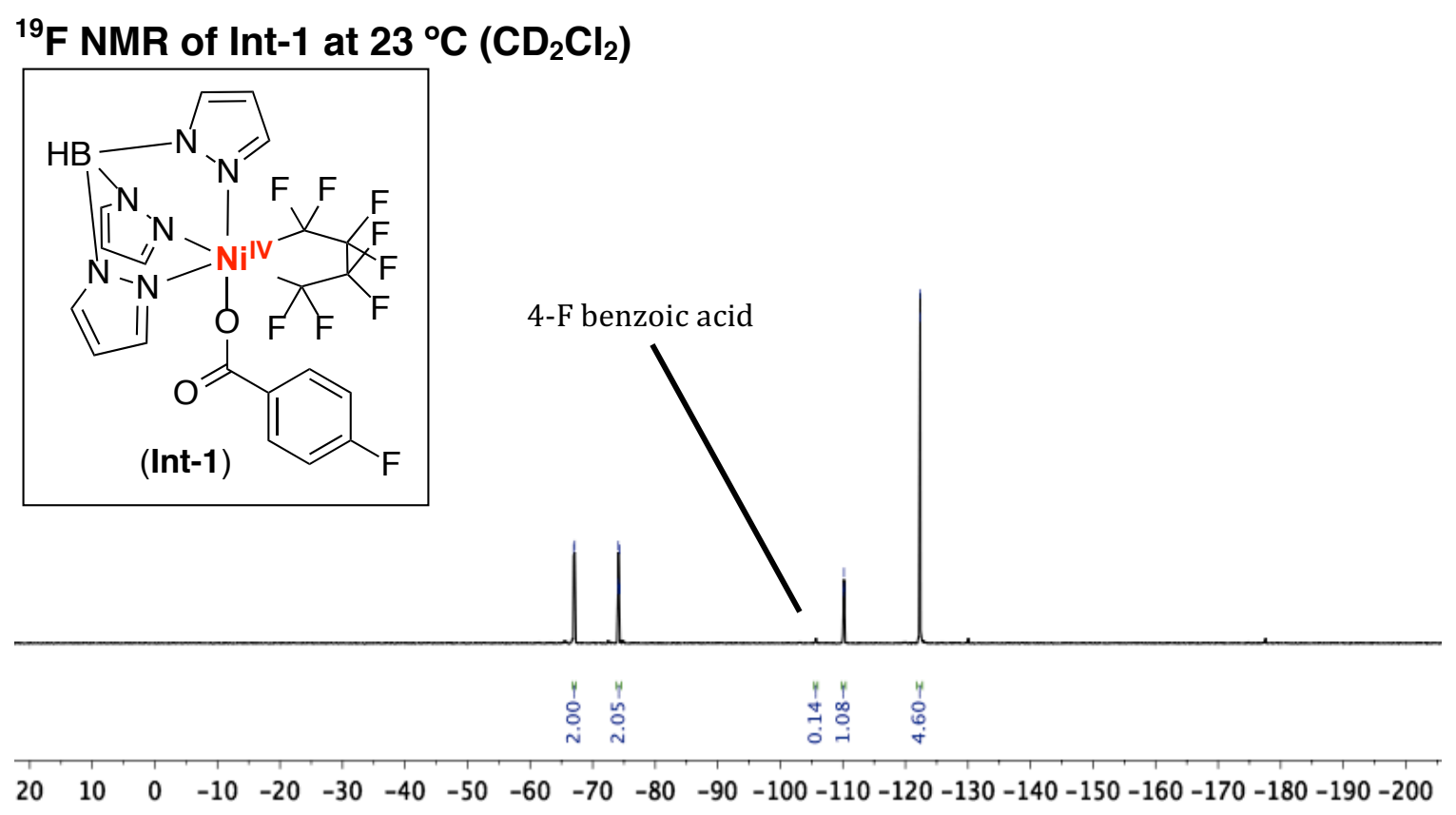




\section{${ }^{1} \mathrm{H}$ NMR of 6 at $23^{\circ} \mathrm{C}\left(\mathrm{CD}_{3} \mathrm{CN}\right)$}

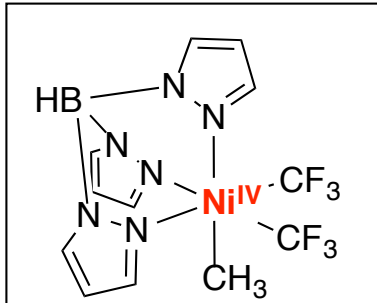

(6)
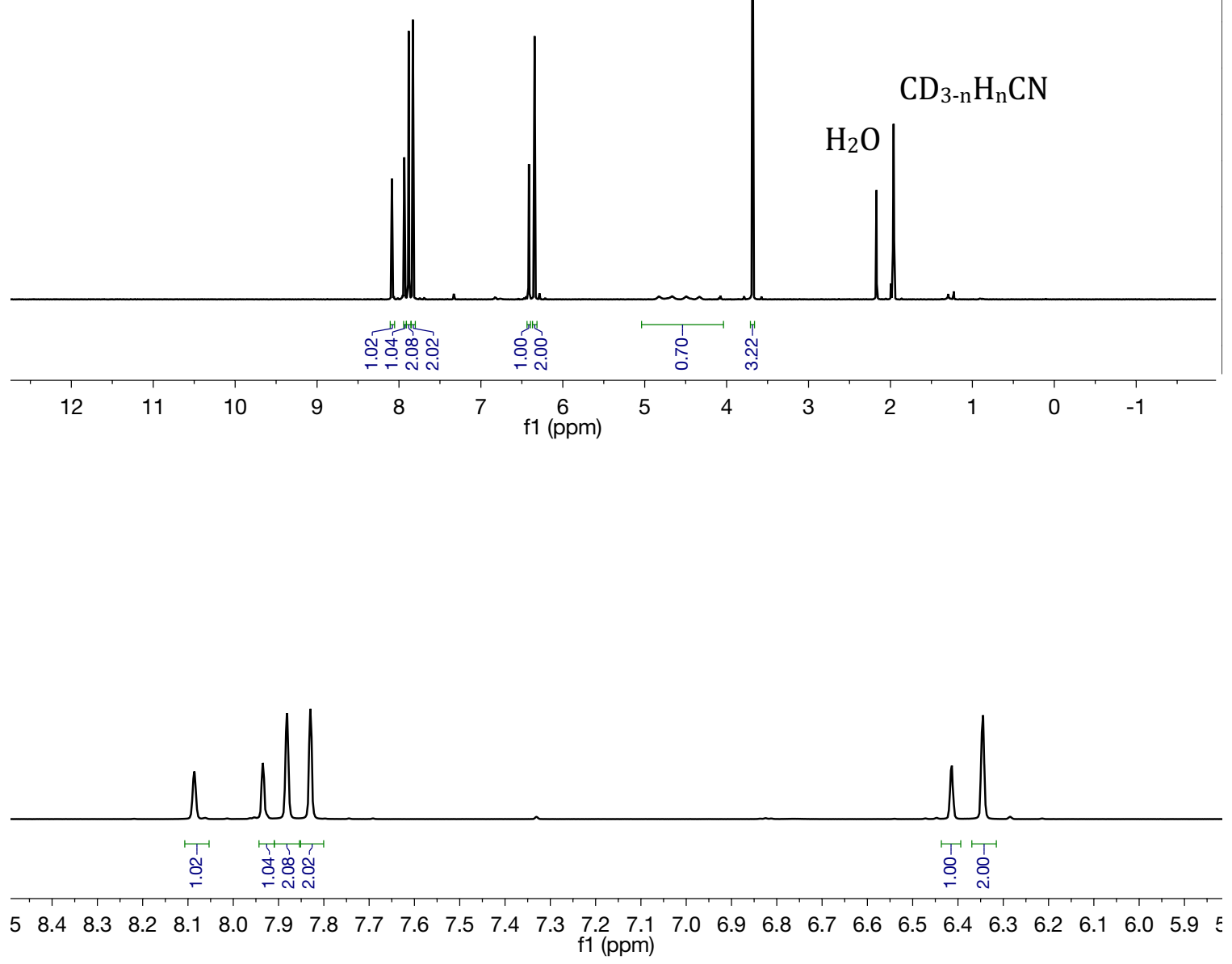
${ }^{11} \mathrm{~B}$ NMR of 6 at $23^{\circ} \mathrm{C}\left(\mathrm{CD}_{3} \mathrm{CN}\right)$

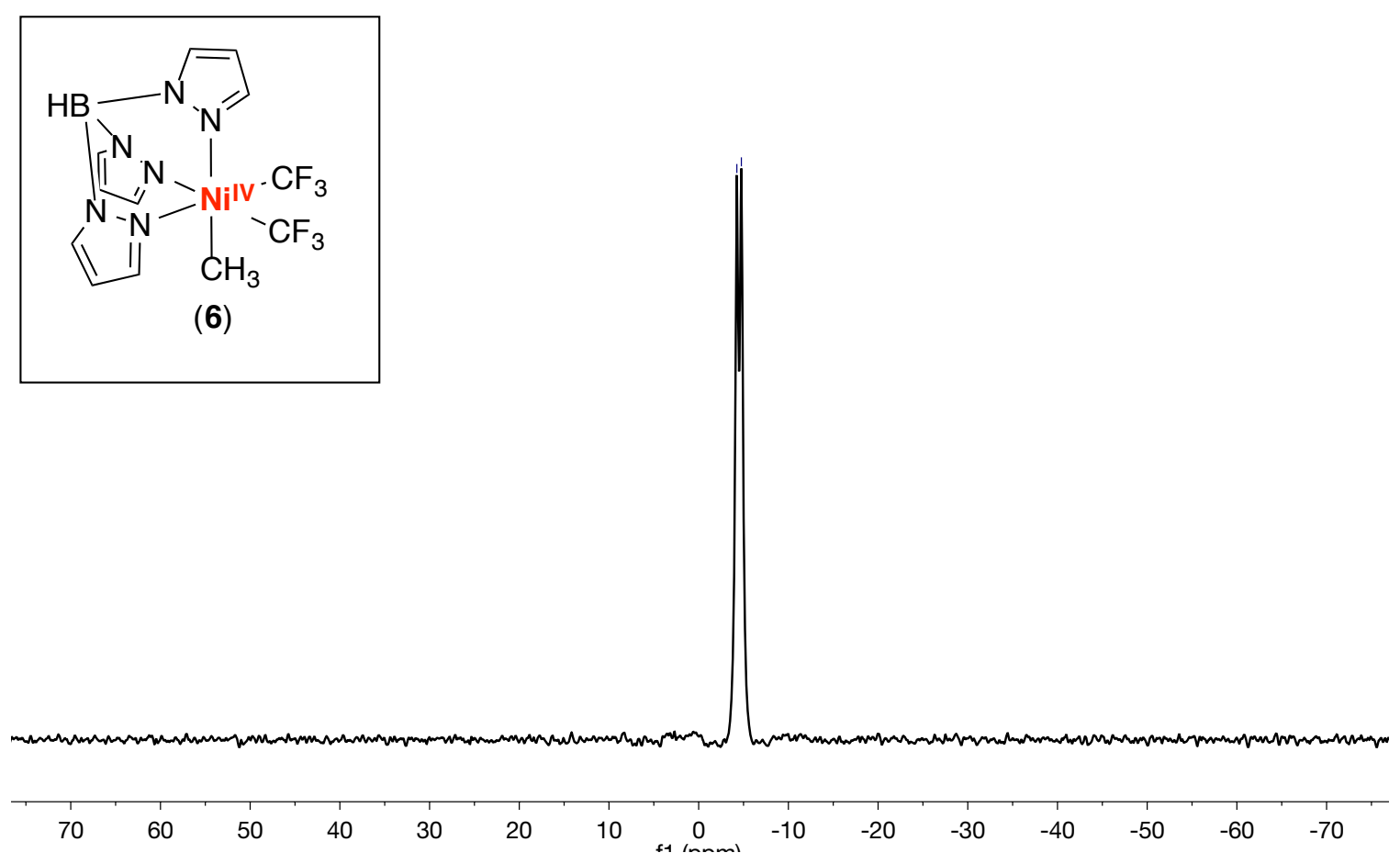




\section{${ }^{13} \mathrm{C}$ NMR of 6 at $23^{\circ} \mathrm{C}\left(\mathrm{CD}_{3} \mathrm{CN}\right)$}

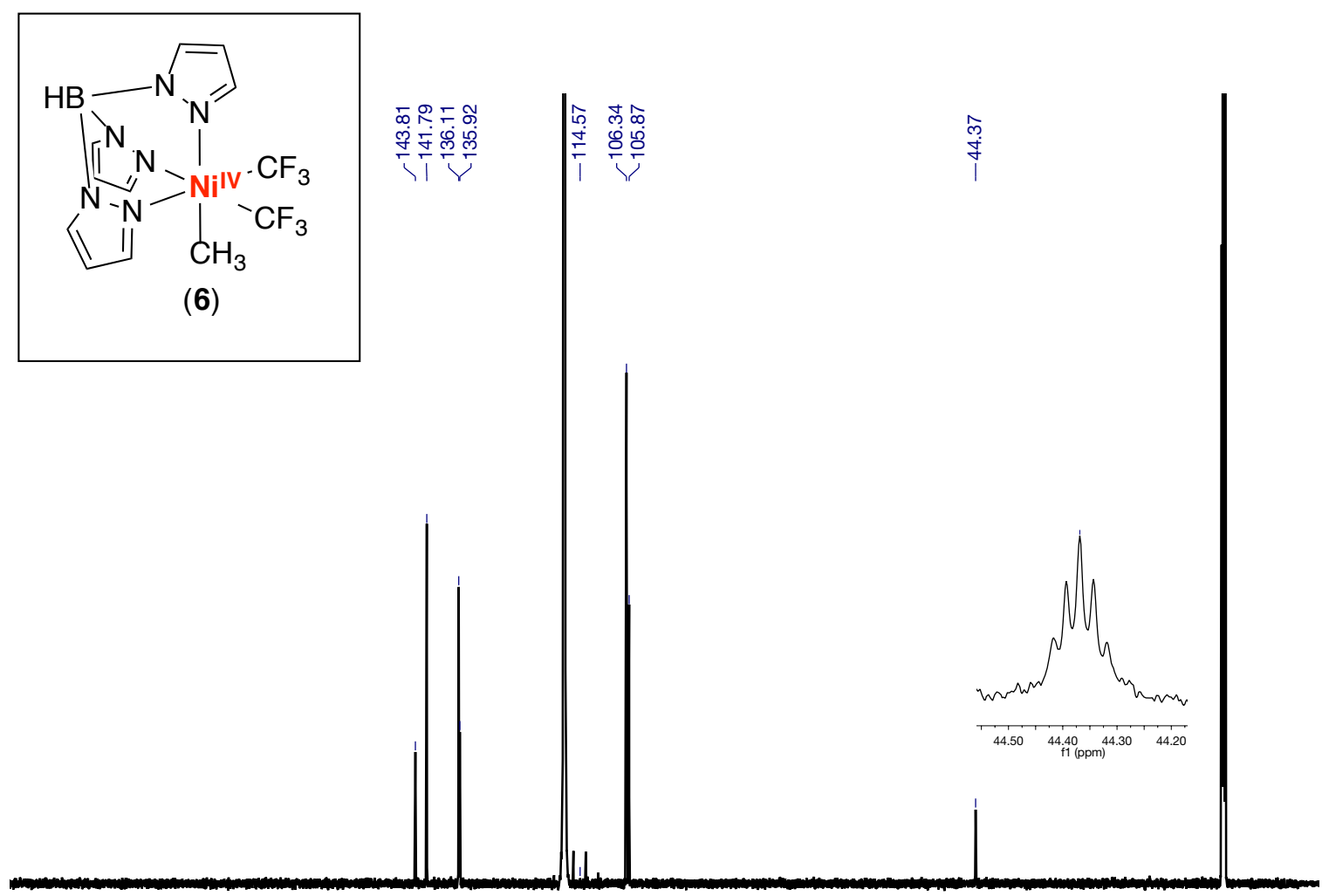

$\begin{array}{lllllllllllllllllllllllll}210 & 200 & 190 & 180 & 170 & 160 & 150 & 140 & 130 & 120 & 110 & 100 & 90 & 80 & 70 & 60 & 50 & 40 & 30 & 20 & 10 & 0 & -10\end{array}$ 


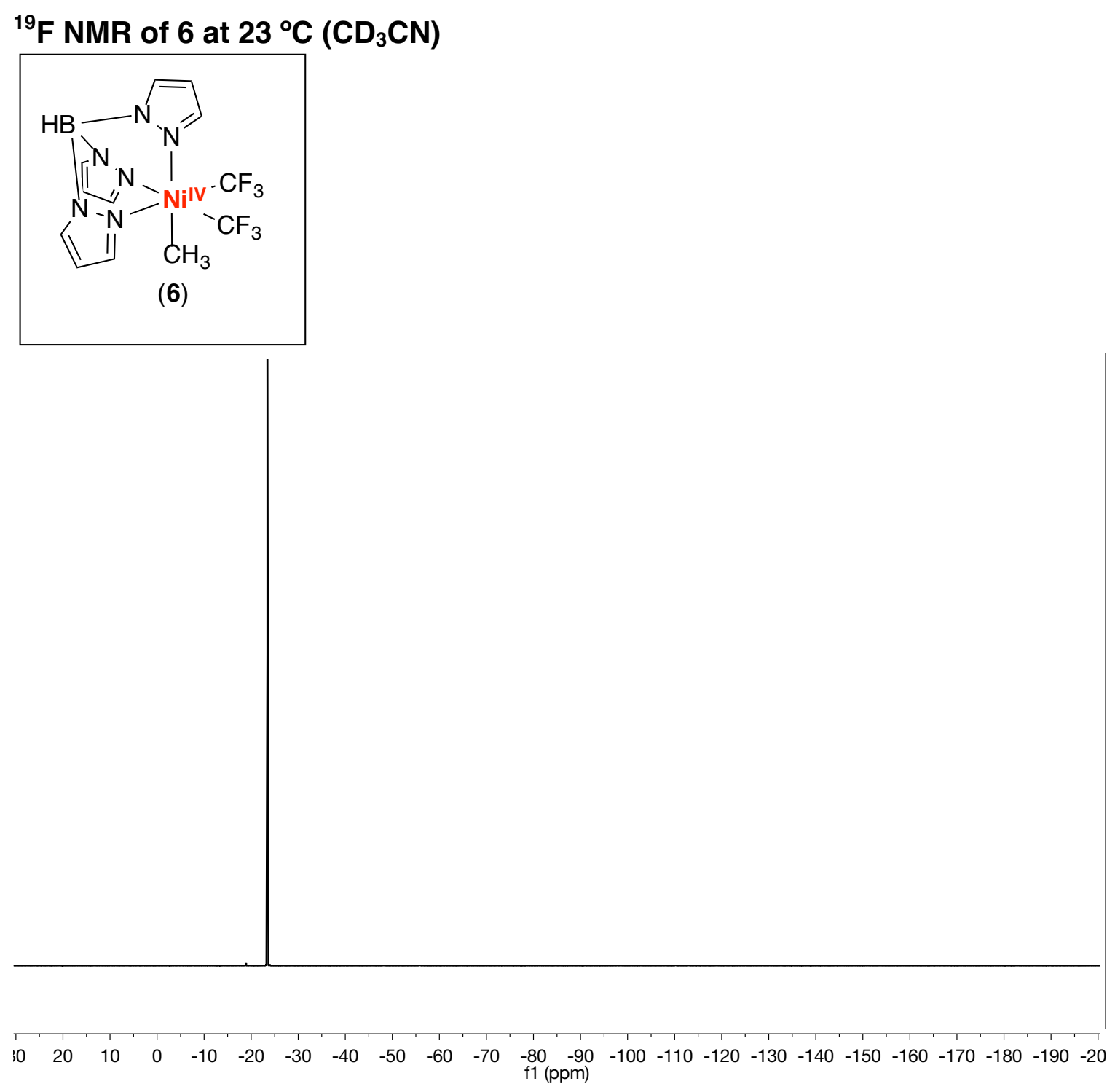




\section{${ }^{1} \mathrm{H} /{ }^{19} \mathrm{~F} \mathrm{HMBC}$ of 6 at $23{ }^{\circ} \mathrm{C}\left(\mathrm{CD}_{3} \mathrm{CN}\right)$}

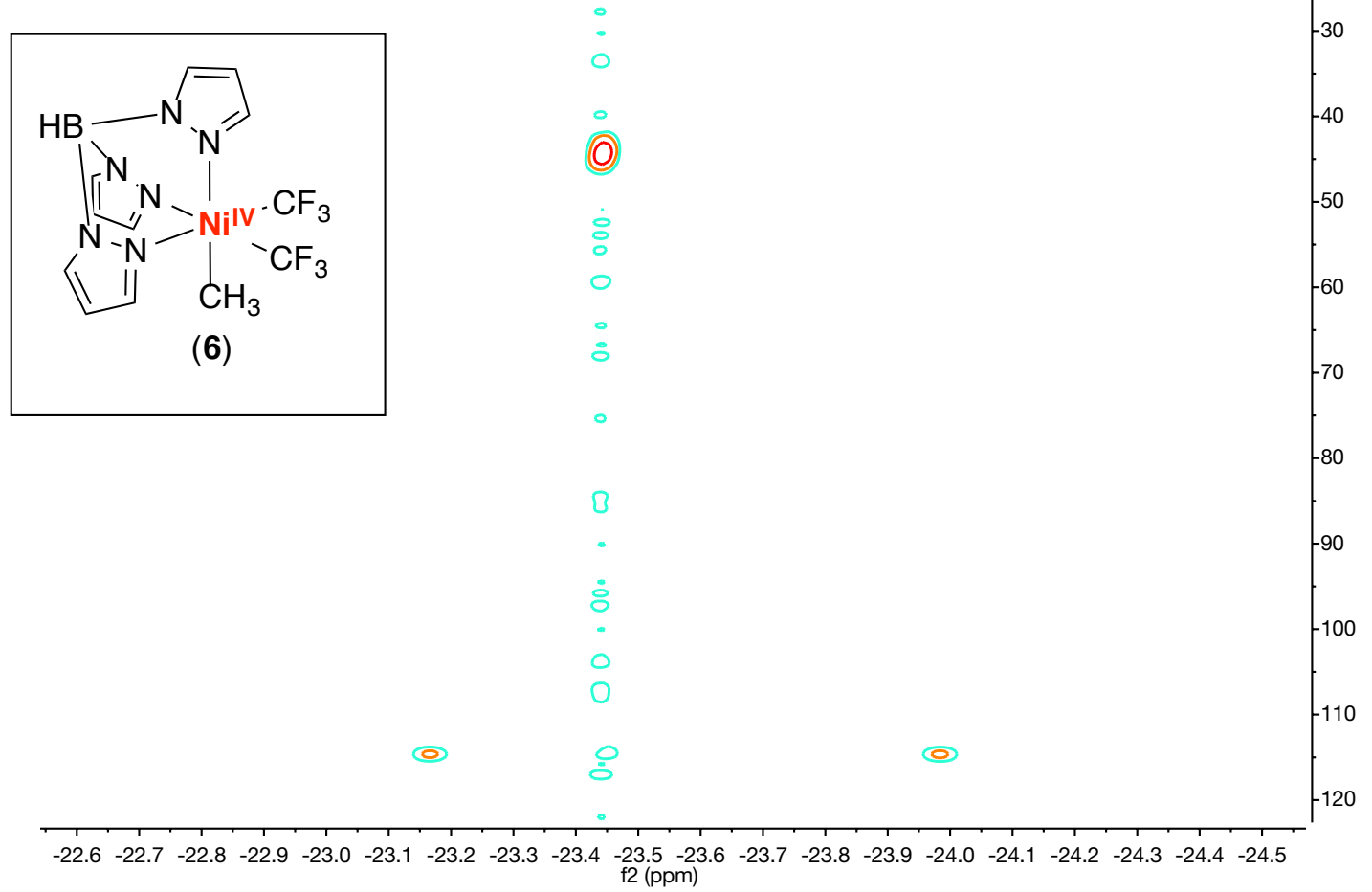


UV-Vis of 6 at $23^{\circ} \mathrm{C}\left(\mathrm{CH}_{3} \mathrm{CN}\right)$
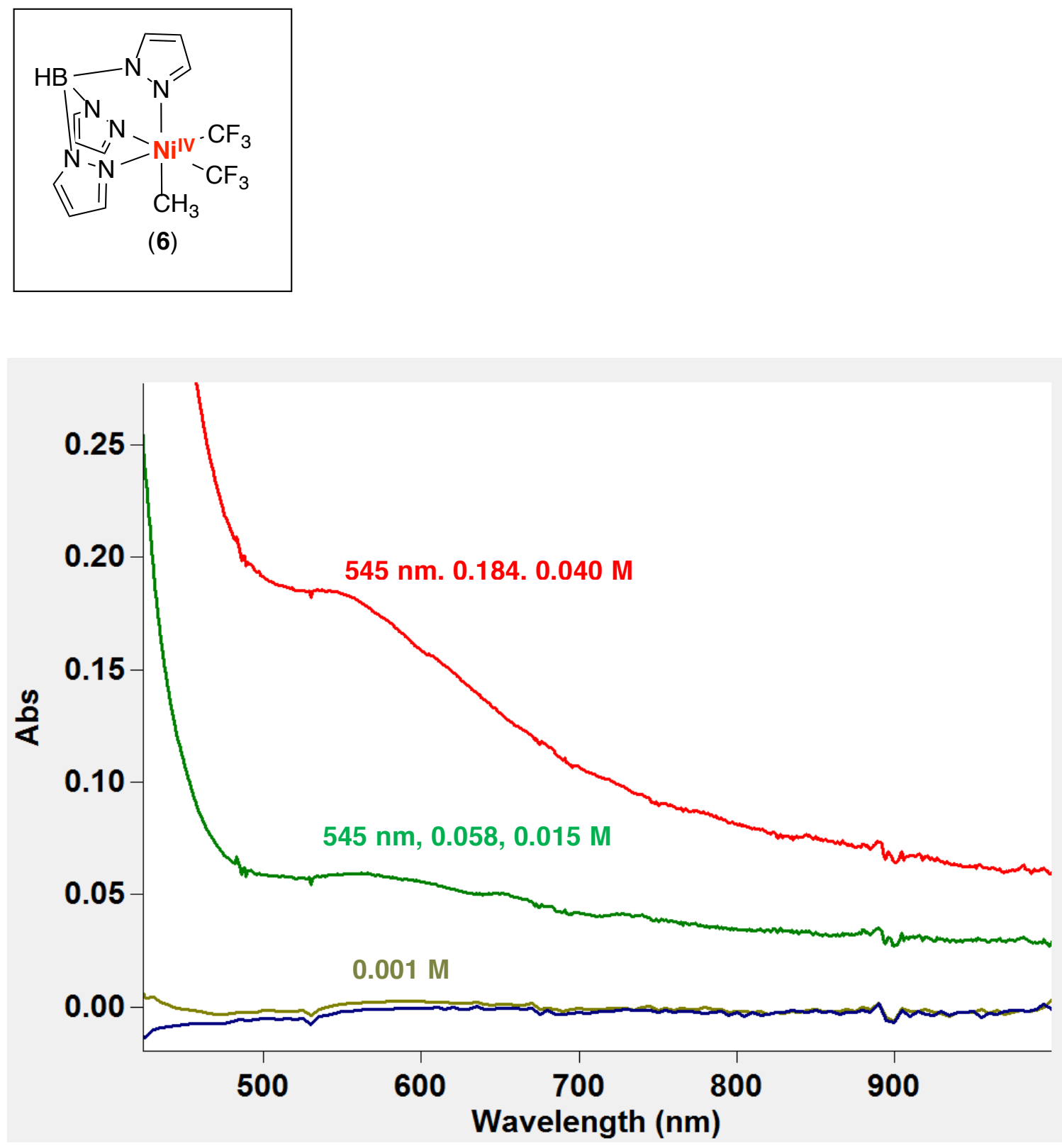
${ }^{1} \mathrm{H}$ NMR of $\mathrm{TpNi}^{\mathrm{iV}}\left(\mathrm{CF}_{3}\right)_{2}\left(\mathrm{CH}_{2} \mathrm{CH}_{3}\right)$ at $23^{\circ} \mathrm{C}\left(\mathrm{CD}_{3} \mathrm{NO}_{2}\right)$
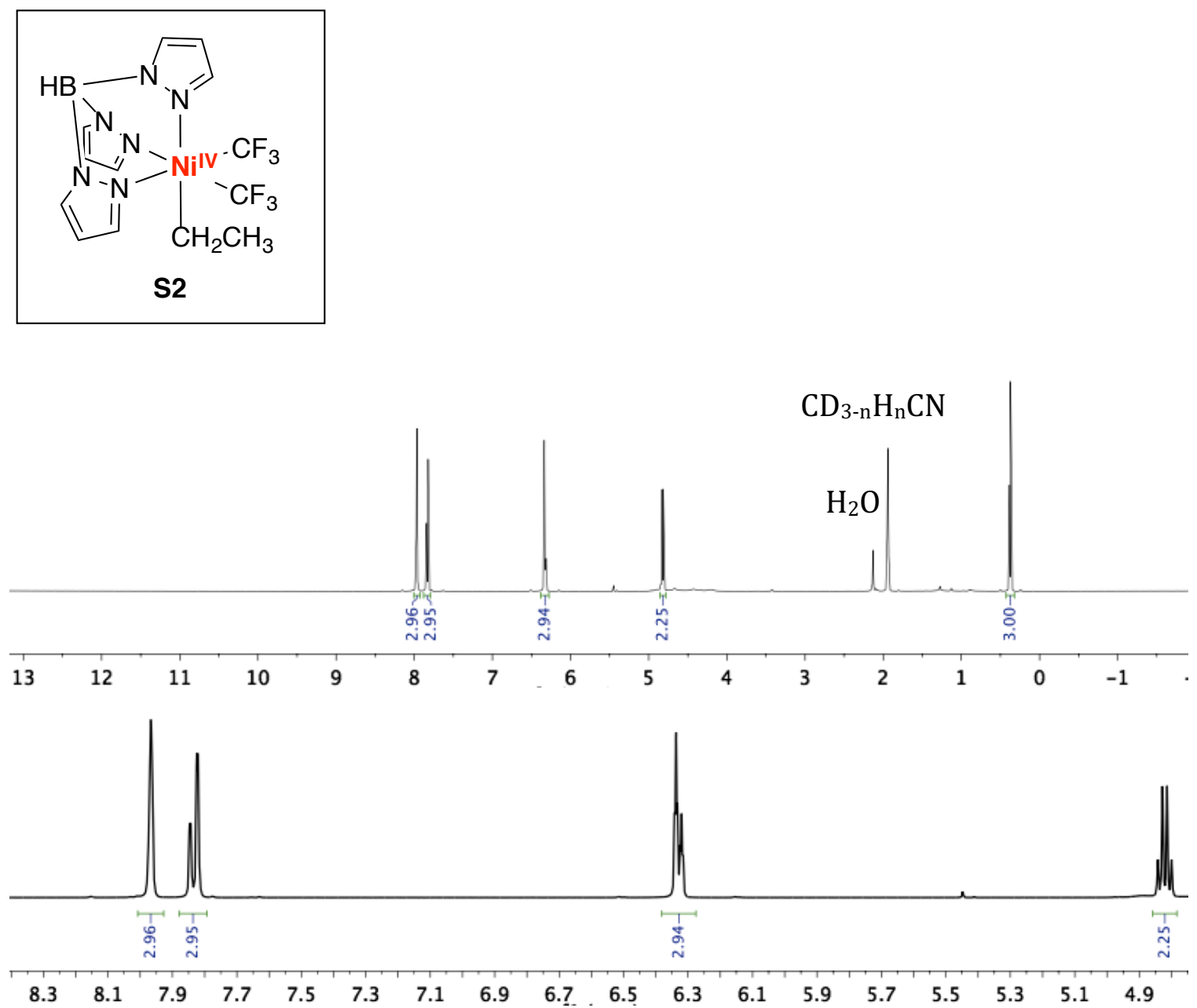
${ }^{11} \mathrm{~B}$ NMR of $\mathrm{TpNi}^{\mathrm{IV}}\left(\mathrm{CF}_{3}\right)_{2}\left(\mathrm{CH}_{2} \mathrm{CH}_{3}\right)$ at $23^{\circ} \mathrm{C}\left(\mathrm{CD}_{3} \mathrm{CN}\right)$
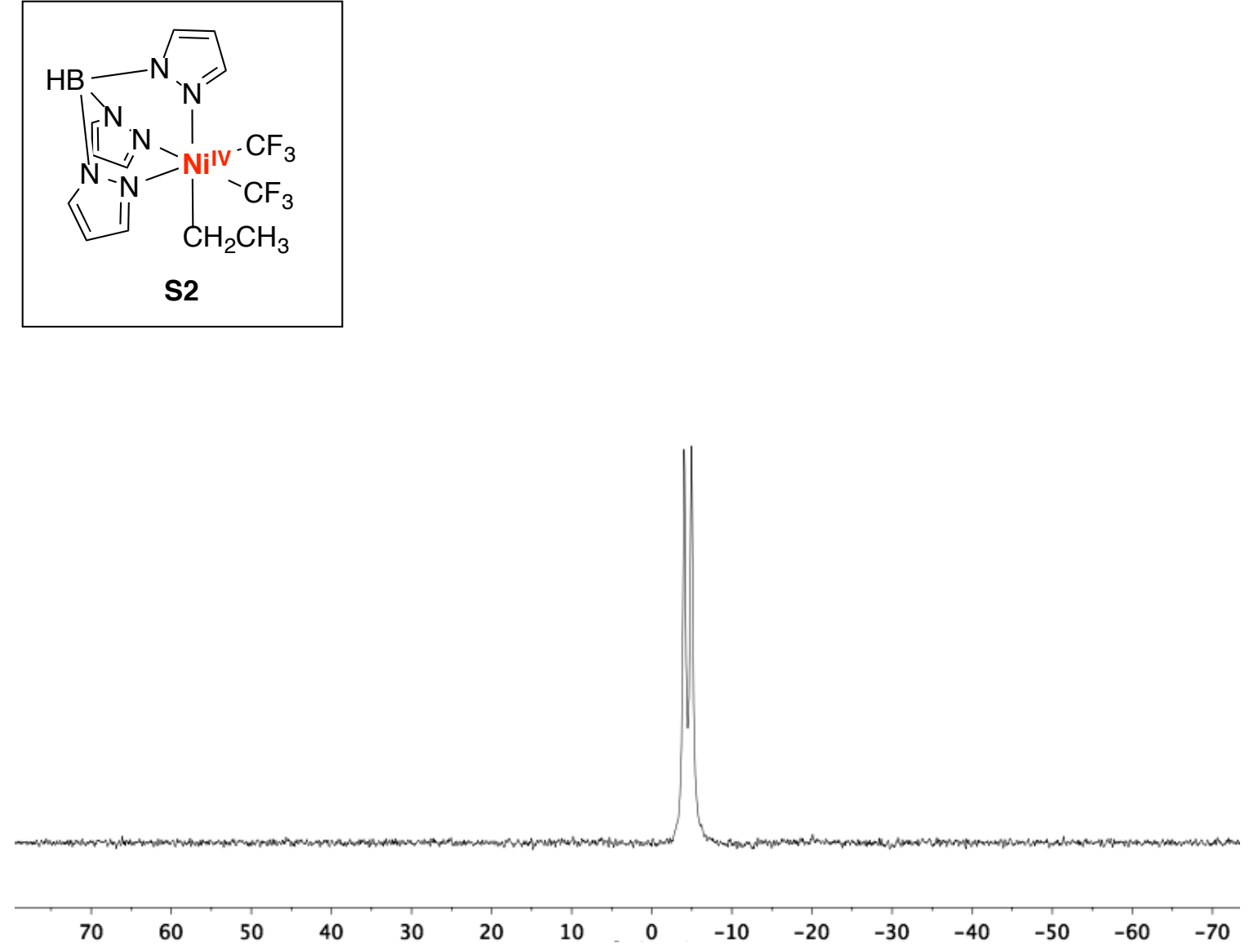

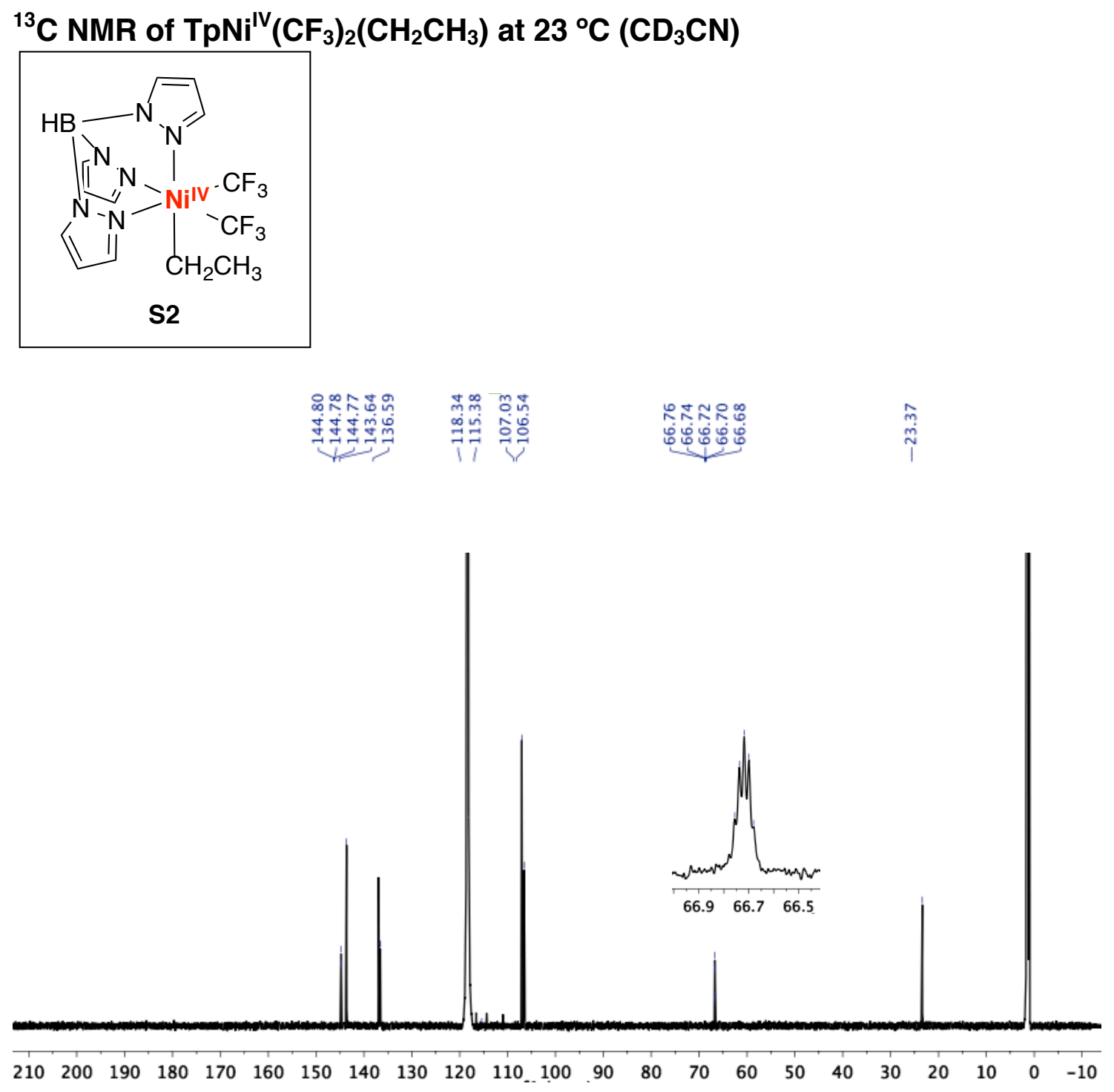
${ }^{19} \mathrm{~F} \mathrm{NMR}$ of $\mathrm{TpNi}^{\mathrm{IV}}\left(\mathrm{CF}_{3}\right)_{2}\left(\mathrm{CH}_{2} \mathrm{CH}_{3}\right)$ at $23^{\circ} \mathrm{C}\left(\mathrm{CD}_{3} \mathrm{CN}\right)$
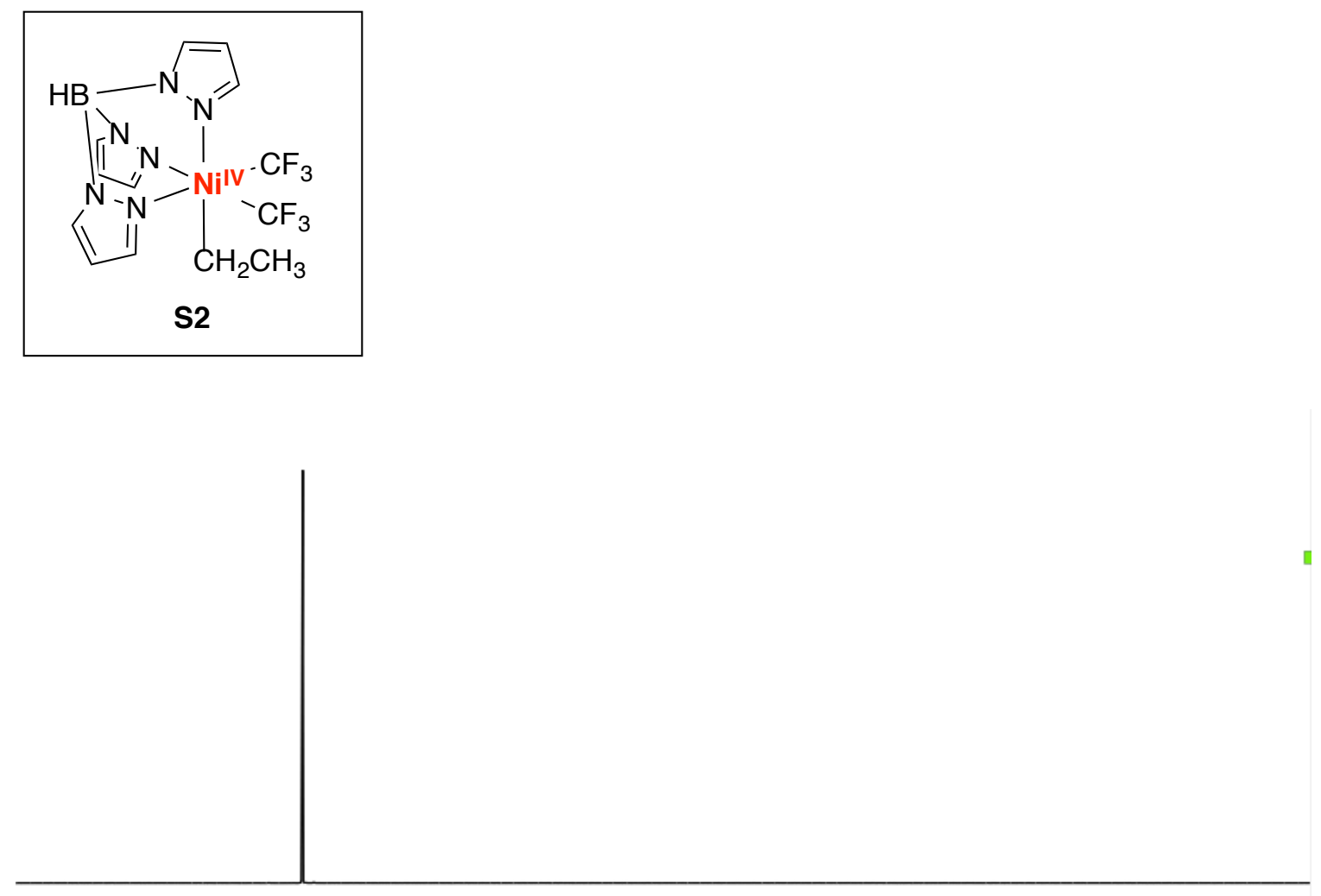

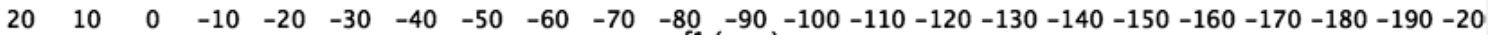


${ }^{1} \mathrm{H}$ NMR of 7 at $23^{\circ} \mathrm{C}\left(\mathrm{CD}_{3} \mathrm{CN}\right)$

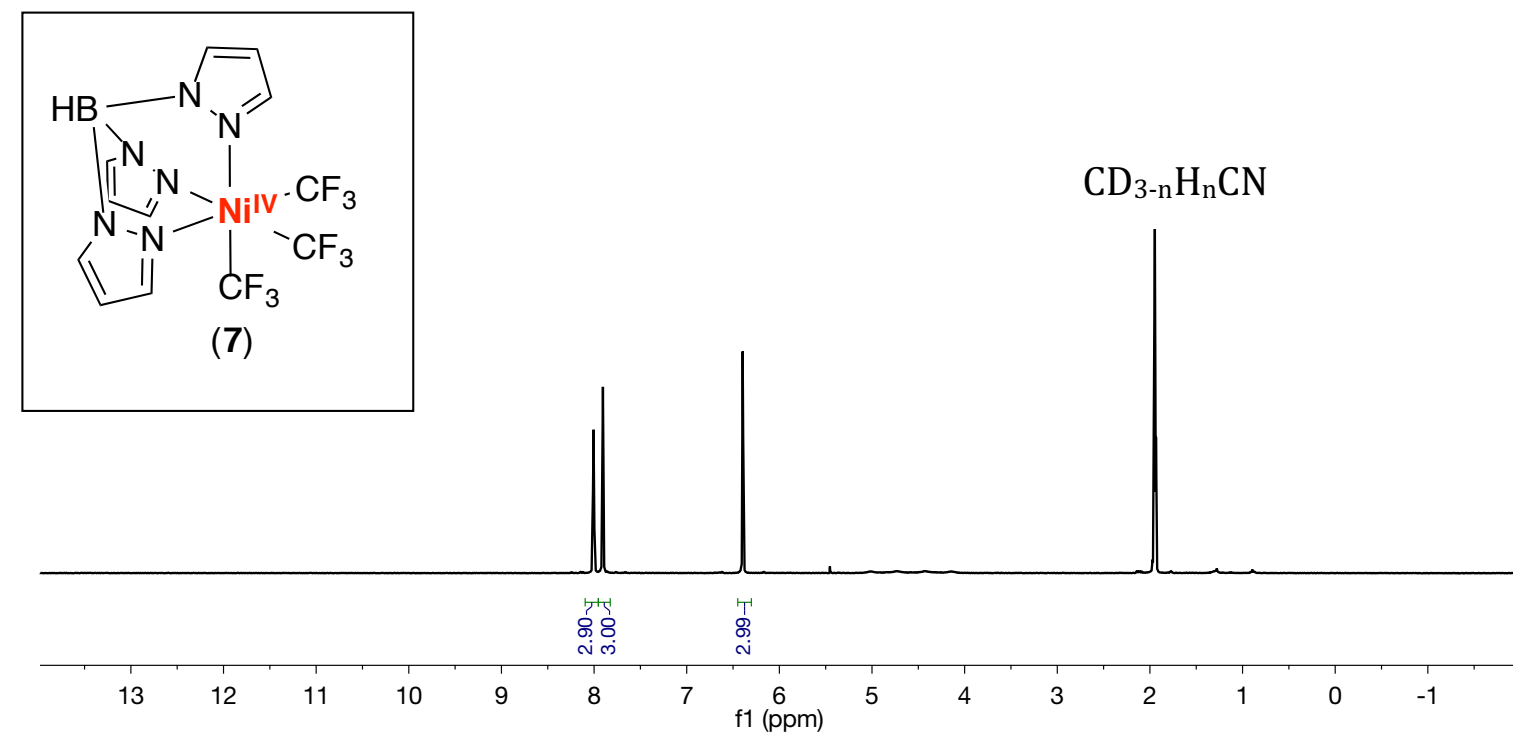




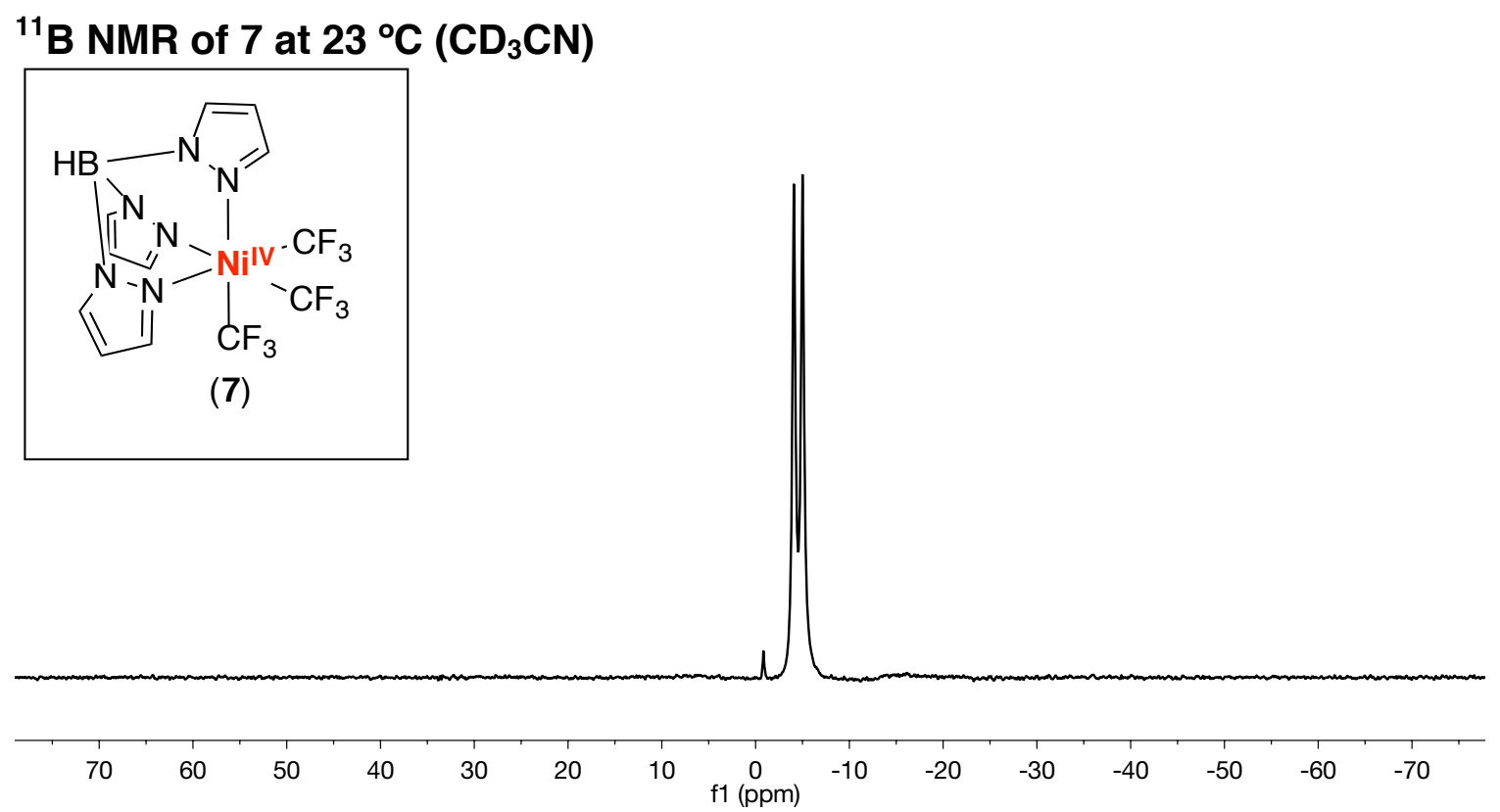



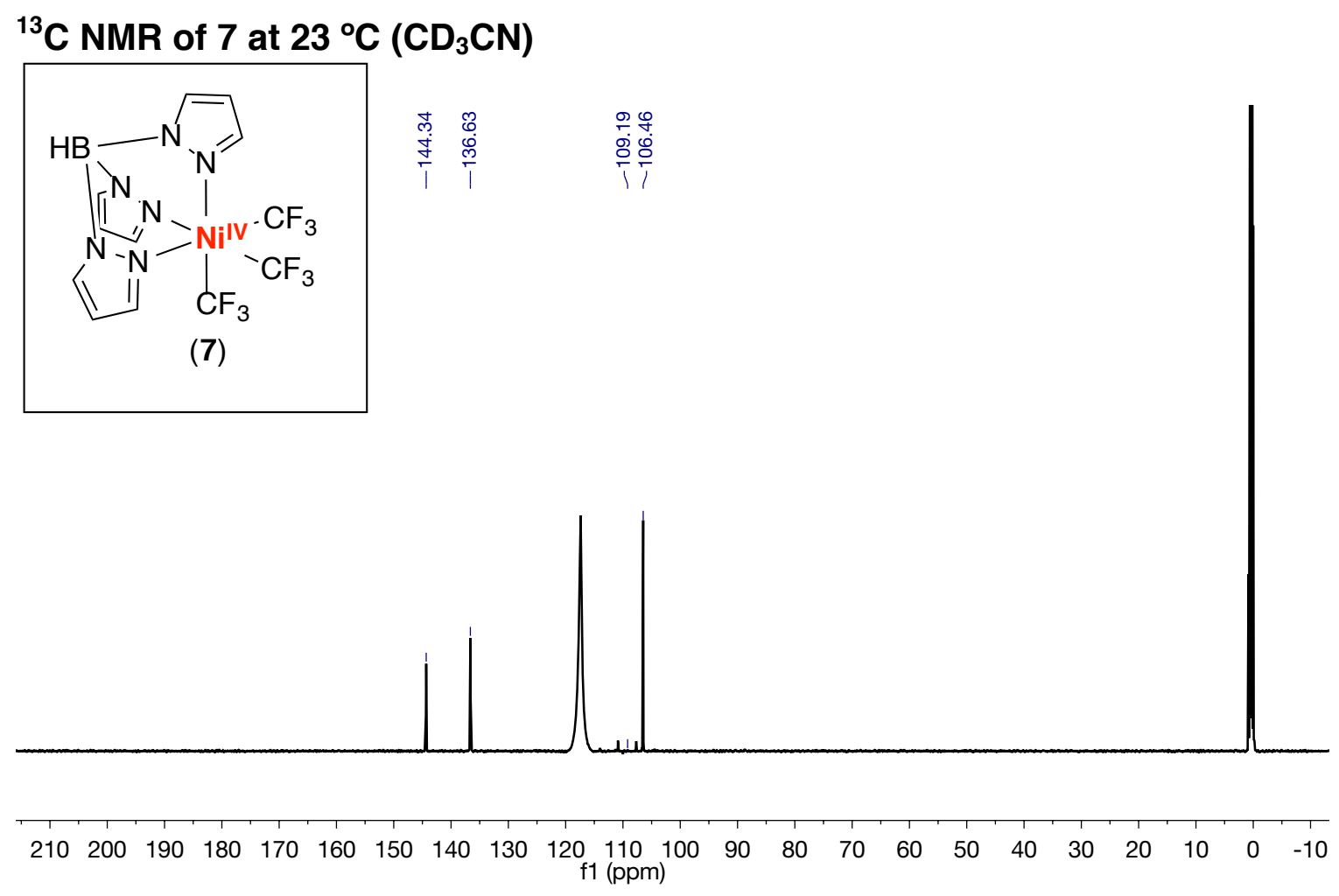


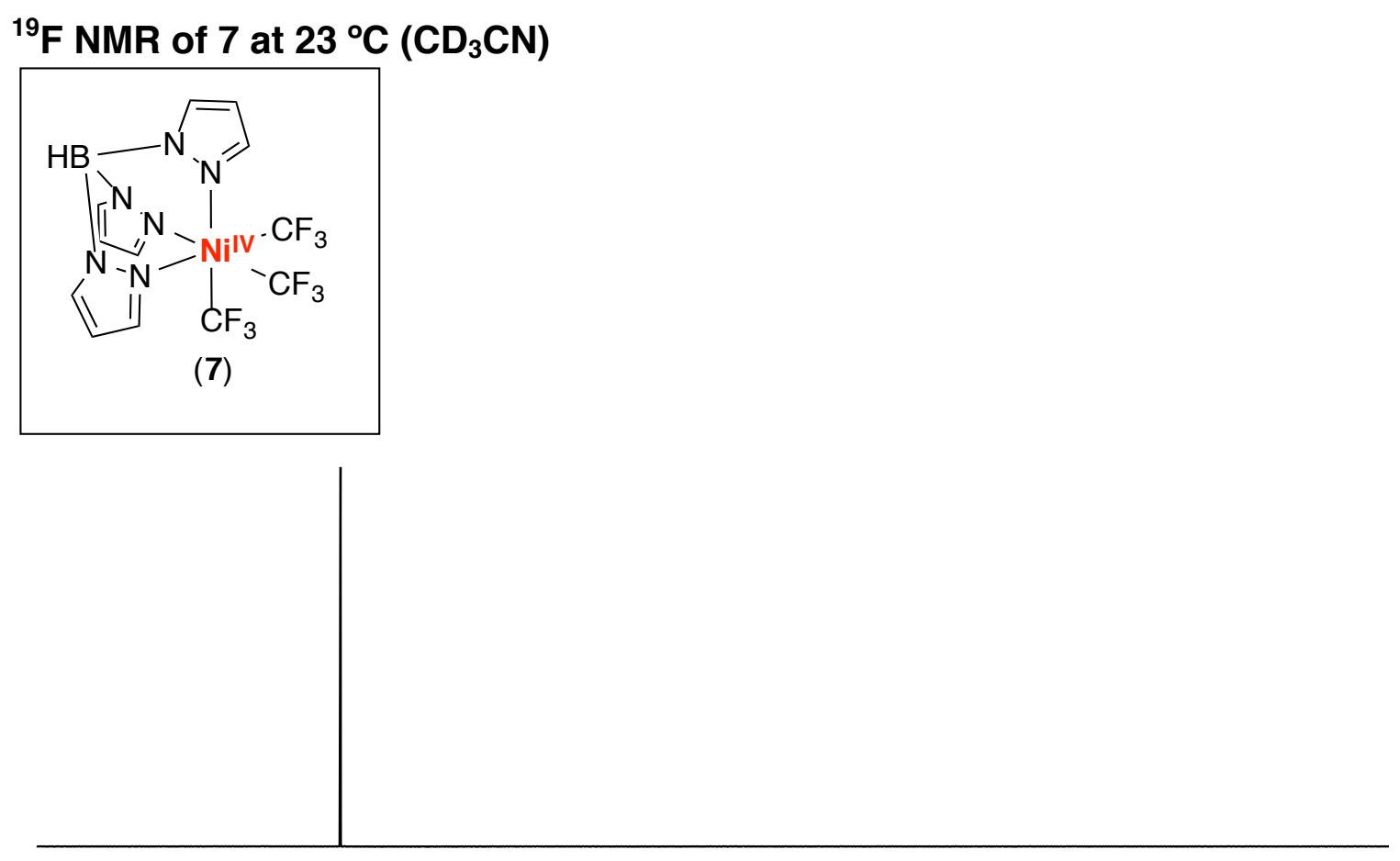

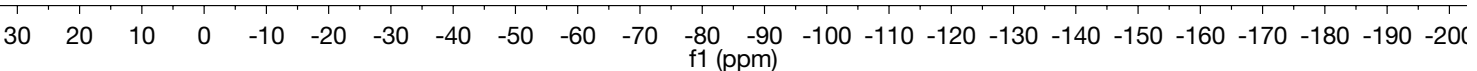




\section{Crystallography Details}

\section{Structure Determination of 3}
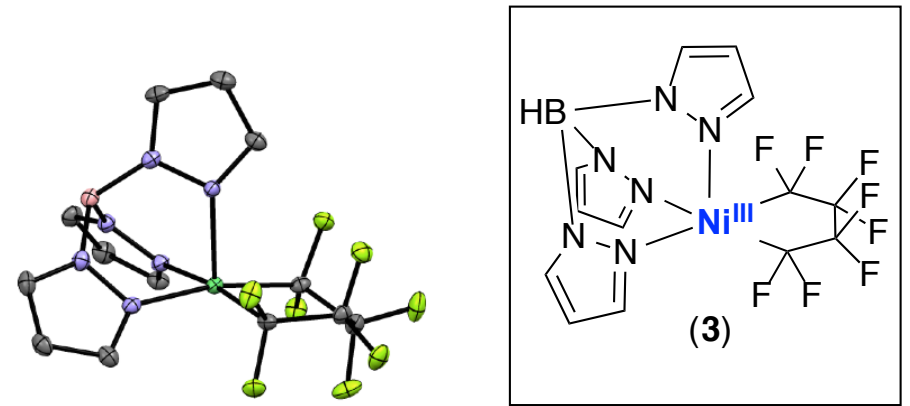

Green needles of 3 were grown from a diethyl ether/pentane solution of the compound at 22 deg. C. A crystal of dimensions $0.17 \times 0.05 \times 0.01 \mathrm{~mm}$ was mounted on a Rigaku AFC10K Saturn 944+ CCD-based X-ray diffractometer equipped with a low temperature device and Micromax-007HF Cu-target micro-focus rotating anode $(\lambda=1.54187 \mathrm{~A})$ operated at $1.2 \mathrm{~kW}$ power $(40 \mathrm{kV}, 30 \mathrm{~mA})$. The X-ray intensities were measured at $85(1)$ $\mathrm{K}$ with the detector placed at a distance $42.00 \mathrm{~mm}$ from the crystal. A total of 2028 images were collected with an oscillation width of $1.0^{\circ}$ in $\omega$. The exposure times were 1 $\mathrm{sec}$. for the low angle images, $4 \mathrm{sec}$. for high angle. Rigaku $\mathrm{d}^{\star}$ trek images were exported to CrysAlisPro for processing and corrected for absorption. The integration of the data yielded a total of 50543 reflections to a maximum $2 \theta$ value of $138.59^{\circ}$ of which 6266 were independent and 6073 were greater than $2 \sigma(\mathrm{I})$. The final cell constants (Table 1) were based on the xyz centroids 33012 reflections above $10 \sigma(\mathrm{I})$. Analysis of the data showed negligible decay during data collection. The structure was solved and refined with the Bruker SHELXTL (version 2014/6) software package, using the space group $\mathrm{P} 2(1) / \mathrm{c}$ with $\mathrm{Z}=8$ for the formula $\mathrm{C}_{13} \mathrm{H}_{10} \mathrm{BN}_{6} \mathrm{~F}_{8} \mathrm{Ni}$. All non-hydrogen atoms were refined anisotropically with the hydrogen atoms placed in idealized positions. Full matrix least-squares refinement based on $F^{2}$ converged at $R 1=0.0294$ and $w R 2=0.0807$ [based on I > 2sigma(I)], R1 $=0.0301$ and $w R 2=0.0815$ for all data. Additional details are presented in Table 1 and are given as Supporting Information in a CIF file. Acknowledgement is made for funding from NSF grant CHE-0840456 for X-ray. 
Table S1. Acquisition and refinement parameters for 3

\begin{tabular}{|c|c|}
\hline Empirical Formula & $\mathrm{C}_{13} \mathrm{H}_{10} \mathrm{BF}_{8} \mathrm{~N}_{6} \mathrm{BNi}$ \\
\hline Formula Weight & 472.29 \\
\hline Temperature & $85(2) \mathrm{K}$ \\
\hline Wavelength & $1.54178 \mathrm{~A}$ \\
\hline Crystal System & Orthorhombic \\
\hline Space Group & $\mathrm{P} 21 / \mathrm{C}$ \\
\hline Unit Cell Dimensions & $\begin{array}{l}a=18.20014(10) \text { A } \quad \text { alpha }=90^{\circ} \\
b=10.42886(5) A \quad \text { beta }=110.9411(6)^{\circ} \\
c=18.97636(9) \text { A } \text { gamma }=90 \mathrm{deg} .\end{array}$ \\
\hline Volume & $3363.93(3) A^{3}$ \\
\hline Z & 8 \\
\hline Calculated Density & $1.863 \mathrm{mg} / \mathrm{m}^{3}$ \\
\hline Absorption Coefficient & $2.616 \mathrm{~mm}^{-1}$ \\
\hline $\mathrm{F}(000)$ & 1880 \\
\hline Crystal Size & $0.170 \times 0.050 \times 0.010 \mathrm{~mm}$ \\
\hline Theta Range for Data Collection & 2.599 to 69.295 deg.deg \\
\hline Limiting Indicies & $-21<=\mathrm{h}<=22,-11<=\mathrm{k}<=12,-22<=\mathrm{l}<=23$ \\
\hline Reflections Collected & 50543 \\
\hline Independent Reflections & $6266[R$ (int) $=0.0414]$ \\
\hline Completeness to Theta & $67.679(99.9 \%)$ \\
\hline Absorption Correction & Semi-empirical from equivalents \\
\hline Max and Min Transmission & 1.00000 and 0.72129 \\
\hline Refinement Method & Full-matrix least-squares on $\mathrm{F}^{2}$ \\
\hline Data / Restraints / Parameters & $6266 / 0 / 523$ \\
\hline Goodness-of-Fit on $\mathrm{F}^{2}$ & 1.015 \\
\hline Final R Indices [l>2 $\sigma(I)]$ & $\mathrm{R} 1=0.0294, \mathrm{wR} 2=0.0807$ \\
\hline $\mathrm{R}$ indices (all data) & $\mathrm{R} 1=0.0301, \mathrm{wR} 2=0.0815$ \\
\hline Largest Difference Peak and Hole & 0.496 and -0.540 e. $A^{\wedge}-3$ \\
\hline
\end{tabular}




\section{Structure Determination of 4}
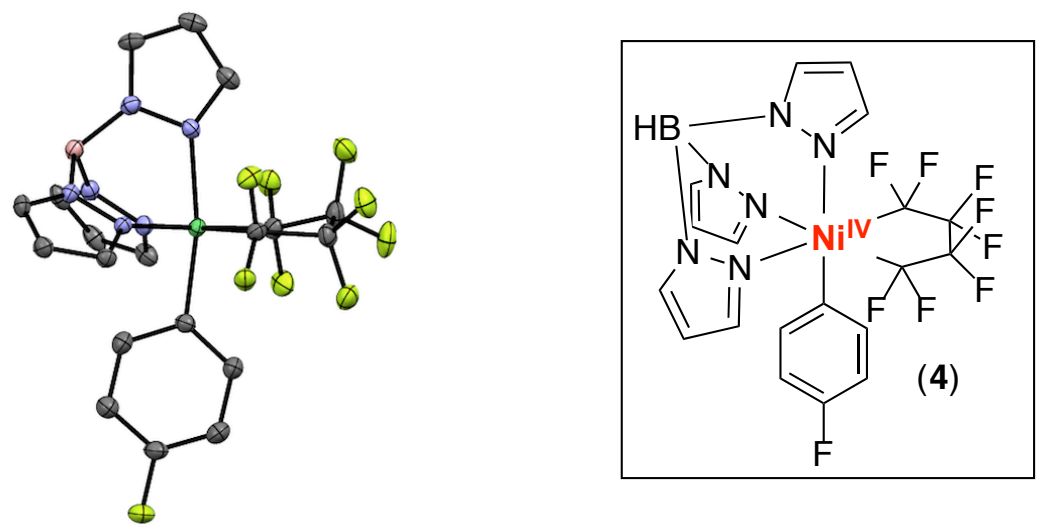

Orange plates of 4 were grown from a pentane solution of the compound at $-20 \mathrm{deg}$. C. A crystal of dimensions $0.06 \times 0.06 \times 0.03 \mathrm{~mm}$ was mounted on a Rigaku AFC10K Saturn 944+ CCD-based X-ray diffractometer equipped with a low temperature device and Micromax-007HF Cu-target micro-focus rotating anode $(\lambda=1.54187 \mathrm{~A})$ operated at $1.2 \mathrm{~kW}$ power $(40 \mathrm{kV}, 30 \mathrm{~mA})$. The X-ray intensities were measured at $85(1) \mathrm{K}$ with the detector placed at a distance $42.00 \mathrm{~mm}$ from the crystal. A total of 2028 images were collected with an oscillation width of $1.0^{\circ}$ in $\omega$. The exposure times were $1 \mathrm{sec}$. for the low angle images, $4 \mathrm{sec}$. for high angle. Rigaku $\mathrm{d}^{*}$ trek images were exported to CrysAlisPro for processing and corrected for absorption. The integration of the data yielded a total of 16508 reflections to a maximum $2 \theta$ value of $138.42^{\circ}$ of which 3901 were independent and 3716 were greater than $2 \sigma(\mathrm{I})$. The final cell constants (Table 1 ) were based on the xyz centroids of 9288 reflections above $10 \sigma(\mathrm{I})$. Analysis of the data showed negligible decay during data collection. The structure was solved and refined with the Bruker SHELXTL (version 2016/6) software package, using the space group $\mathrm{P} 1$ bar with $\mathrm{Z}=2$ for the formula $\mathrm{C}_{19} \mathrm{H}_{14} \mathrm{BN}_{6} \mathrm{~F} 9 \mathrm{Ni}$. All non-hydrogen atoms were refined anisotropically with the hydrogen atoms placed in idealized positions. Full matrix leastsquares refinement based on $\mathrm{F}^{2}$ converged at $\mathrm{R} 1=0.0439$ and $\mathrm{wR} 2=0.1189$ [based on I > 2sigma(I)], R1 $=0.0457$ and $w R 2=0.1214$ for all data. Additional details are presented in Table 1 and are given as Supporting Information in a CIF file. Acknowledgement is made for funding from NSF grant CHE-0840456 for X-ray instrumentation. 
Table S2. Acquisition and refinement parameters for 4

\begin{tabular}{|c|c|}
\hline Empirical Formula & $\mathrm{C}_{19} \mathrm{H}_{14} \mathrm{BF}_{9} \mathrm{~N}_{6} \mathrm{BNi}$ \\
\hline Formula Weight & 566.88 \\
\hline Temperature & $85(2) \mathrm{K}$ \\
\hline Wavelength & $1.54184 \mathrm{~A}$ \\
\hline Crystal System & Orthorhombic \\
\hline Space Group & Pna2(1) \\
\hline Unit Cell Dimensions & $\begin{array}{l}\mathrm{a}=9.5099(3) \text { A } \text { alpha }=98.118(2)^{\circ} \\
\mathrm{b}=9.9578(3) \text { A }{\text { beta }=92.716(2)^{\circ}}^{\circ} \\
\mathrm{c}=12.0931(3) \mathrm{A} \text { gamma }= \\
106.997(3)^{\circ}\end{array}$ \\
\hline Volume & $1079.43(6) A^{3}$ \\
\hline Z & 2 \\
\hline Calculated Density & $1.744 \mathrm{mg} / \mathrm{m}^{3}$ \\
\hline Absorption Coefficient & $2.231 \mathrm{~mm}^{-1}$ \\
\hline$F(000)$ & 568 \\
\hline Crystal Size & $0.060 \times 0.060 \times 0.030 \mathrm{~mm}$ \\
\hline Theta Range for Data Collection & 3.708 to 69.212 deg.deg \\
\hline Limiting Indicies & $-11<=\mathrm{h}<=11,-11<=\mathrm{k}<=11,-14<=\mathrm{l}<=14$ \\
\hline Reflections Collected & 16508 \\
\hline Independent Reflections & $3901[R$ (int) $=0.0503]$ \\
\hline Completeness to Theta & $67.684(97.8 \%)$ \\
\hline Absorption Correction & Semi-empirical from equivalents \\
\hline Max and Min Transmission & 1.000000 .91740 \\
\hline Refinement Method & Full-matrix least-squares on $\mathrm{F}^{2}$ \\
\hline Data / Restraints / Parameters & $3099 / 1 / 259$ \\
\hline Goodness-of-Fit on $\mathrm{F}^{2}$ & 1.109 \\
\hline 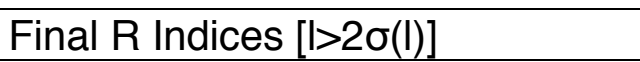 & $\mathrm{R} 1=0.0439, \mathrm{wR} 2=0.1189$ \\
\hline $\mathrm{R}$ indices (all data) & $\mathrm{R} 1=0.0457, \mathrm{wR} 2=0.1214$ \\
\hline Largest Difference Peak and Hole & 1.229 and -0.368 e. $A^{\wedge}-3$ \\
\hline
\end{tabular}




\section{Structure Determination of 5}

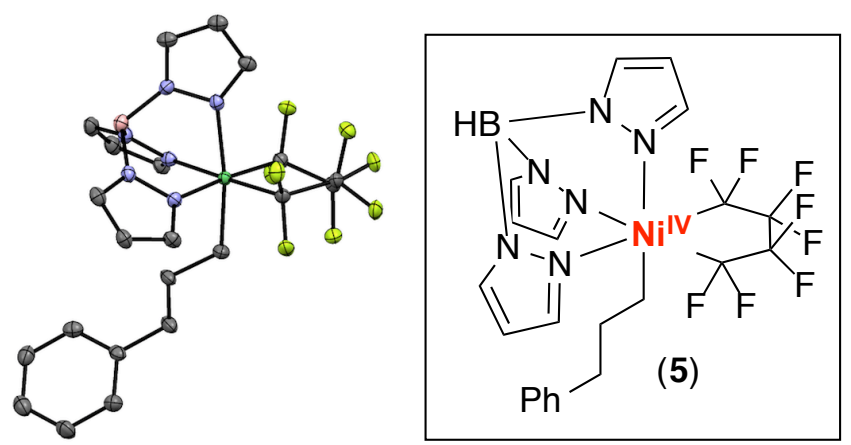

Yellow prisms of 5 were grown from a pentane solution of the compound at -22 deg. C. A crystal of dimensions $0.15 \times 0.09 \times 0.09 \mathrm{~mm}$ was mounted on a Rigaku AFC10K Saturn 944+ CCD-based X-ray diffractometer equipped with a low temperature device and Micromax-007HF Cu-target micro-focus rotating anode ( $=1.54187 \mathrm{~A})$ operated at $1.2 \mathrm{~kW}$ power $(40 \mathrm{kV}, 30 \mathrm{~mA})$. The X-ray intensities were measured at $85(1) \mathrm{K}$ with the detector placed at a distance $42.00 \mathrm{~mm}$ from the crystal. A total of 2028 images were collected with an oscillation width of 1.0 in The exposure times were $1 \mathrm{sec}$. for the low angle images, $3 \mathrm{sec}$. for high angle. Rigaku $\mathrm{d}^{\star}$ trek images were exported to CrysAlisPro for processing and corrected for absorption. The integration of the data yielded a total of 36328 reflections to a maximum 2 value of 138.56 of which 4509 were independent and 4444 were greater than 2 (I). The final cell constants (Table 1) were based on the xyz centroids 27038 reflections above 10 (I). Analysis of the data showed negligible decay during data collection. The structure was solved and refined with the Bruker SHELXTL (version 2016/6) software package, using the space group $\mathrm{P} 2(1) / \mathrm{n}$ with $\mathrm{Z}=4$ for the formula $\mathrm{C}_{22} \mathrm{H}_{21} \mathrm{BN}_{6} \mathrm{~F}_{6} \mathrm{Ni}$. All non-hydrogen atoms were refined anisotropically with the hydrogen atoms placed in idealized positions. Full matrix least-squares refinement based on $F^{2}$ converged at $R 1=0.0332$ and $w R 2=0.0862$ [based on I > 2sigma(I)], R1 $=0.0336$ and $w R 2=0.0865$ for all data. Additional details are presented in Table 1 and are given as Supporting Information in a CIF file. Acknowledgement is made for funding from NSF grant CHE-0840456 for X-ray instrumentation 
Table S3. Acquisition and refinement parameters for 5

\begin{tabular}{|c|c|}
\hline Empirical Formula & $\mathrm{C}_{22} \mathrm{H}_{21} \mathrm{BF}_{8} \mathrm{~N}_{6} \mathrm{BNi}$ \\
\hline Formula Weight & 590.97 \\
\hline Temperature & $85(2) \mathrm{K}$ \\
\hline Wavelength & $1.54184 \mathrm{~A}$ \\
\hline Crystal System & Orthorhombic \\
\hline Space Group & $\mathrm{P} 21 / \mathrm{N}$ \\
\hline Unit Cell Dimensions & $\begin{array}{ll}a=10.18015(5) \mathrm{A} & \text { alpha }=90^{\circ} \\
\mathrm{b}=18.14258(9) \mathrm{A} & \text { beta }=96.6667^{\circ} \\
\mathrm{c}=13.24800(6) \mathrm{A} & \text { gamma }^{\circ} 90^{\circ}\end{array}$ \\
\hline Volume & $2430.28(3) A^{3}$ \\
\hline Z & 4 \\
\hline Calculated Density & $1.615 \mathrm{mg} / \mathrm{m}^{3}$ \\
\hline Absorption Coefficient & $1.945 \mathrm{~mm}^{-1}$ \\
\hline$F(000)$ & 1200 \\
\hline Crystal Size & $0.150 \times 0.090 \times 0.09 \mathrm{~mm}$ \\
\hline Theta Range for Data Collection & 4.150 to $69.282^{\circ}$ \\
\hline Limiting Indicies & $-12<=h<=12,-22<=\mathrm{k}<=21,-15<=\mid<=16$ \\
\hline Reflections Collected & 36328 \\
\hline Independent Reflections & $4509[\mathrm{R}(\mathrm{int})=0.0621]$ \\
\hline Completeness to Theta & $67.684(100 \%)$ \\
\hline Absorption Correction & Semi-empirical from equivalents \\
\hline Max and Min Transmission & 0.7366 and 0.6464 \\
\hline Refinement Method & Full-matrix least-squares on $\mathrm{F}^{2}$ \\
\hline Data / Restraints / Parameters & 4509 / 0 / 344 \\
\hline Goodness-of-Fit on $\mathrm{F}^{2}$ & 1.069 \\
\hline Final R Indices [l>2 $\sigma(I)]$ & $\mathrm{R} 1=0.0332, \mathrm{wR} 2=0.0862$ \\
\hline $\mathrm{R}$ indices (all data) & $\mathrm{R} 1=0.0336, \mathrm{wR} 2=0.0865$ \\
\hline Largest Difference Peak and Hole & 0.333 and -0.470 e. $. A^{\wedge}-3$ \\
\hline
\end{tabular}




\section{Structure Determination of Int-1}
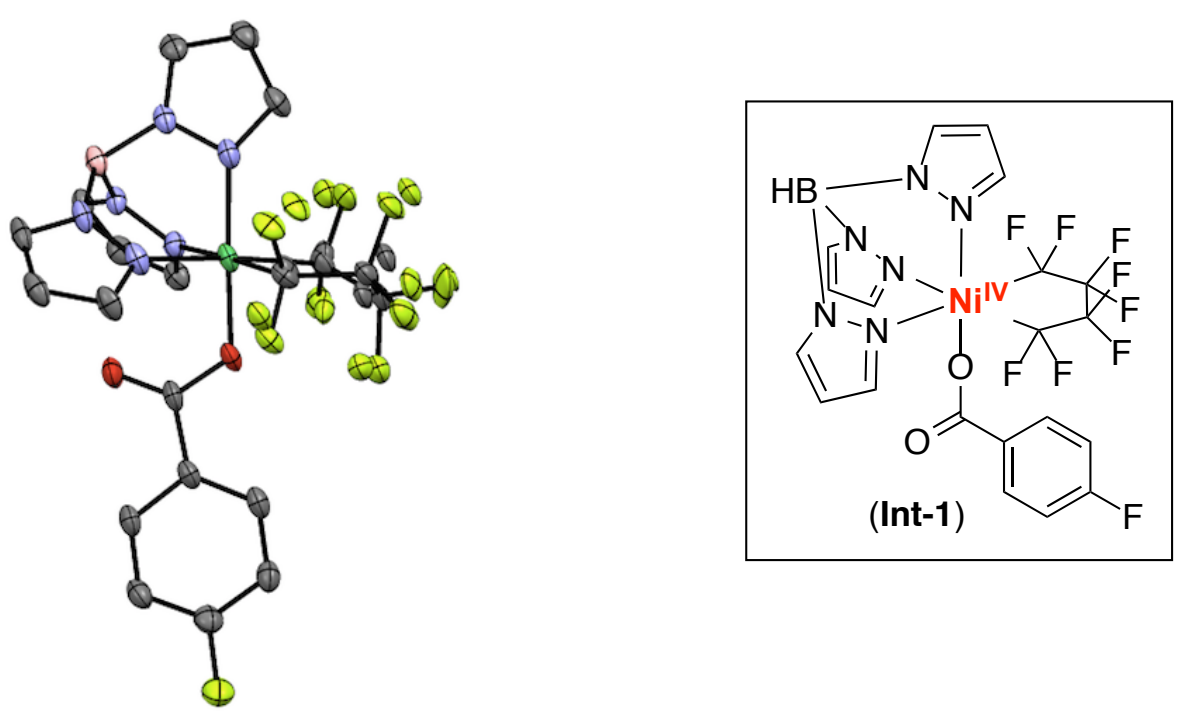

Orange needles of Int-1 were grown from a toluene/pentane solution of the compound at -35 deg. C. A crystal of dimensions $0.20 \times 0.05 \times 0.02 \mathrm{~mm}$ was mounted on a Rigaku AFC10K Saturn 944+ CCD-based X-ray diffractometer equipped with a low temperature device and Micromax-007HF Cu-target micro-focus rotating anode $(\lambda=1.54187 \mathrm{~A})$ operated at $1.2 \mathrm{~kW}$ power $(40 \mathrm{kV}, 30 \mathrm{~mA})$. The $\mathrm{X}$-ray intensities were measured at $85(1) \mathrm{K}$ with the detector placed at a distance $42.00 \mathrm{~mm}$ from the crystal. A total of 2028 images were collected with an oscillation width of $1.0^{\circ}$ in $\omega$. The exposure times were $3 \mathrm{sec}$. for the low angle images, $15 \mathrm{sec}$. for high angle. Rigaku $\mathrm{d}^{\star}$ trek images were exported to CrysAlisPro for processing and corrected for absorption. The integration of the data yielded a total of 35814 reflections to a maximum $2 \theta$ value of $138.72^{\circ}$ of which 6315 were independent and 4876 were greater than $2 \sigma(I)$. The final cell constants (Table 1 ) were based on the xyz centroids of 10476 reflections above $10 \sigma(\mathrm{I})$. Analysis of the data showed negligible decay during data collection. The structure was solved and refined with the Bruker SHELXTL (version 2018/3) software package, using the space group $\mathrm{P} 2(1) / \mathrm{n}$ with $\mathrm{Z}=4$ for the formula $\mathrm{C}_{2} \mathrm{H}_{14} \mathrm{BN}_{6} \mathrm{O}_{2} \mathrm{~F} 9 \mathrm{Ni}$. The crystal was determined to be a two-component, non-merohedral twin. The domains were related by a 179.82 deg. rotation about the direct $\left(\begin{array}{lll}1 & 0 & 0\end{array}\right)$ axis. Reflections from both components as well as overlaps were used as the basis for the HKLF5 format input file. The fractional twin ratio refined to $0.544(2) / 0.456(2)$. The ocatafluorobutyl ligand was also disordered in two orientations (relative occupancy $0.688(6) / 0.312(6)$ related by a torsional twist. All non-hydrogen atoms were refined anisotropically with the hydrogen atoms placed in idealized positions. Full matrix leastsquares refinement based on $\mathrm{F}^{2}$ converged at $\mathrm{R} 1=0.0672$ and $\mathrm{wR} 2=0.1642$ [based on $\mathrm{I}>$ 2sigma(I)], R1 $=0.0774$ and $w R 2=0.1694$ for all data. Additional details are presented in Table 1 and are given as Supporting Information in a CIF file. Acknowledgement is made for funding from NSF grant CHE-0840456 for X-ray instrumentation.

G.M. Sheldrick (2015) "Crystal structure refinement with SHELXL", Acta Cryst., C71, 3-8 (Open Access).

CrystalClear Expert 2.0 r16, Rigaku Americas and Rigaku Corporation (2014), Rigaku 
Americas, 9009, TX, USA 77381-5209, Rigaku Tokyo, 196-8666, Japan.

CrysAlisPro 1.171.38.41 (Rigaku Oxford Diffraction, 2015)

Table S4. Acquisition and refinement parameters for Int-1b

\begin{tabular}{|c|c|}
\hline Empirical Formula & $\mathrm{C}_{20} \mathrm{H}_{14} \mathrm{BF}_{9} \mathrm{~N}_{6} \mathrm{BO}_{2} \mathrm{Ni}$ \\
\hline Formula Weight & 610.89 \\
\hline Temperature & $85(2) \mathrm{K}$ \\
\hline Wavelength & $1.54184 \mathrm{~A}$ \\
\hline Crystal System & Monoclinic \\
\hline Space Group & $\mathrm{P} 2(1) / \mathrm{n}$ \\
\hline Unit Cell Dimensions & $\begin{array}{lc}a=7.3536(3) \mathrm{A} & \text { alpha }=90^{\circ} \\
\mathrm{b}=17.7538(5) \mathrm{A} & \text { beta }=95.986(3)^{\circ} \\
\mathrm{c}=17.6299(1) \mathrm{A} & {\text { gamma }=90^{\circ}}^{\circ}\end{array}$ \\
\hline Volume & $2289.11(13) A^{3}$ \\
\hline Z & 4 \\
\hline Calculated Density & $1.773 \mathrm{mg} / \mathrm{m}^{3}$ \\
\hline Absorption Coefficient & $2.226 \mathrm{~mm}^{-1}$ \\
\hline$F(000)$ & 1224 \\
\hline Crystal Size & $0.20 \times 0.050 \times 0.02 \mathrm{~mm}$ \\
\hline Theta Range for Data Collection & 3.543 to $69.361^{\circ}$ \\
\hline Limiting Indicies & $-8<=h<=8,-21<=k<=21,-19<=\mathrm{k}<=20$ \\
\hline Reflections Collected & 35814 \\
\hline Independent Reflections & $6315[R($ int $)=0.1675]$ \\
\hline Completeness to Theta & $67.684(98.1 \%)$ \\
\hline Absorption Correction & Semi-empirical from equivalents \\
\hline Max and Min Transmission & 1.0000 and 0.63079 \\
\hline Refinement Method & Full-matrix least-squares on $\mathrm{F}^{2}$ \\
\hline Data / Restraints / Parameters & 6315 / 345 / 462 \\
\hline Goodness-of-Fit on $\mathrm{F}^{2}$ & 1.154 \\
\hline Final R Indices $[\mid>2 \sigma(I)]$ & $R 1=0.0672, w R 2=0.1642$ \\
\hline $\mathrm{R}$ indices (all data) & $\mathrm{R} 1=0.0774, \mathrm{wR} 2=0.1694$ \\
\hline Largest Difference Peak and Hole & 0.947 and -0.975 e. $A^{\wedge}-3$ \\
\hline
\end{tabular}




\section{Structure Determination of 7}

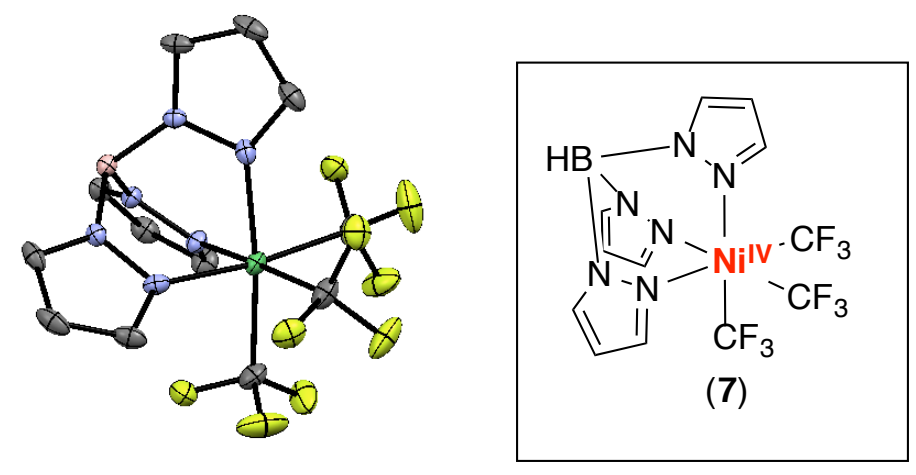

Yellow needles of 7 were grown from a diethylether/pentane solution of the compound at 22 deg. C. A crystal of dimensions $0.15 \times 0.05 \times 0.02 \mathrm{~mm}$ was mounted on a Rigaku AFC10K Saturn 944+ CCD-based X-ray diffractometer equipped with a low temperature device and Micromax-007HF Cu-target micro-focus rotating anode $(\lambda=1.54187 \mathrm{~A})$ operated at $1.2 \mathrm{~kW}$ power $(40 \mathrm{kV}, 30 \mathrm{~mA})$. The X-ray intensities were measured at $85(1)$ $\mathrm{K}$ with the detector placed at a distance $42.00 \mathrm{~mm}$ from the crystal. A total of 2028 images were collected with an oscillation width of $1.0^{\circ}$ in $\omega$. The exposure times were 3 $\mathrm{sec}$. for the low angle images, $15 \mathrm{sec}$. for high angle. The integration of the data yielded a total of 24534 reflections to a maximum $2 \theta$ value of $136.04^{\circ}$ of which 1575 were independent and 1516 were greater than $2 \sigma(\mathrm{I})$. The final cell constants (Table 1) were based on the xyz centroids 9051 reflections above $10 \sigma(\mathrm{l})$. Analysis of the data showed negligible decay during data collection; the data were processed with CrystalClear 2.0 and corrected for absorption. The structure was solved and refined with the Bruker SHELXTL (version 2008/4) software package, using the space group Pnma with $Z=4$ for the formula $\mathrm{C}_{12} \mathrm{H}_{10} \mathrm{BN}_{6} \mathrm{~F} 9 \mathrm{Ni}$. All non-hydrogen atoms were refined anisotropically with the hydrogen atoms placed in a combination of idealized and refined positions. The complex lies on a mirror plane of the crystal lattice. Full matrix least-squares refinement based on $\mathrm{F}^{2}$ converged at $\mathrm{R} 1=0.0364$ and $\mathrm{wR} 2=0.1025$ [based on I > 2sigma(I)], R1 $=0.0370$ and $w R 2=0.1031$ for all data. Additional details are presented in Table 1 and are given as Supporting Information in a CIF file. Acknowledgement is made for funding from NSF grant CHE-0840456 for X-ray instrumentation. 
Table S5. Acquisition and refinement parameters for 7

\begin{tabular}{|c|c|}
\hline Empirical Formula & $\mathrm{C}_{12} \mathrm{H}_{10} \mathrm{BF}_{9} \mathrm{~N}_{6} \mathrm{BNi}$ \\
\hline Formula Weight & 478.78 \\
\hline Temperature & $85(2) \mathrm{K}$ \\
\hline Wavelength & $1.54178 \mathrm{~A}$ \\
\hline Crystal System & Orthorhombic \\
\hline Space Group & Pnma \\
\hline Unit Cell Dimensions & $\begin{array}{ll}\mathrm{a}=16.0863(11 \mathrm{~A} & \text { alpha }=90^{\circ} \\
\mathrm{b}=13.4144(3) \mathrm{A} & \text { beta }=90^{\circ} \\
\mathrm{c}=7.63650(1) \mathrm{A} & \text { gamma }=90^{\circ}\end{array}$ \\
\hline Volume & $1647.87(12) A^{3}$ \\
\hline Z & 4 \\
\hline Calculated Density & $1.930 \mathrm{mg} / \mathrm{m}^{3}$ \\
\hline Absorption Coefficient & $2.769 \mathrm{~mm}^{-1}$ \\
\hline $\mathrm{F}(000)$ & 952 \\
\hline Crystal Size & $0.150 \times 0.050 \times 0.02 \mathrm{~mm}$ \\
\hline Theta Range for Data Collection & 4.150 to $69.282^{\circ}$ \\
\hline Limiting Indicies & $-19<=\mathrm{h}<=18,-16<=\mathrm{k}<=16,-9<=\mathrm{k}<=9$ \\
\hline Reflections Collected & 24534 \\
\hline Independent Reflections & $1575[R($ int $)=0.0608]$ \\
\hline Completeness to Theta & $68.02(100 \%)$ \\
\hline Absorption Correction & Semi-empirical from equivalents \\
\hline Max and Min Transmission & 0.9467 and 0.6815 \\
\hline Refinement Method & Full-matrix least-squares on $\mathrm{F}^{2}$ \\
\hline Data / Restraints / Parameters & $1575 / 0 / 148$ \\
\hline Goodness-of-Fit on $\mathrm{F}^{2}$ & 1.095 \\
\hline Final R Indices [l>2 $\sigma(I)]$ & $\mathrm{R} 1=0.0364, \mathrm{wR} 2=0.1025$ \\
\hline $\mathrm{R}$ indices (all data) & $\mathrm{R} 1=0.3070, \mathrm{wR} 2=0.1031$ \\
\hline Largest Difference Peak and Hole & 0.367 and -0.373 e. $A^{\wedge}-3$ \\
\hline
\end{tabular}

